\title{
JAPANFOUNDATION 86
}
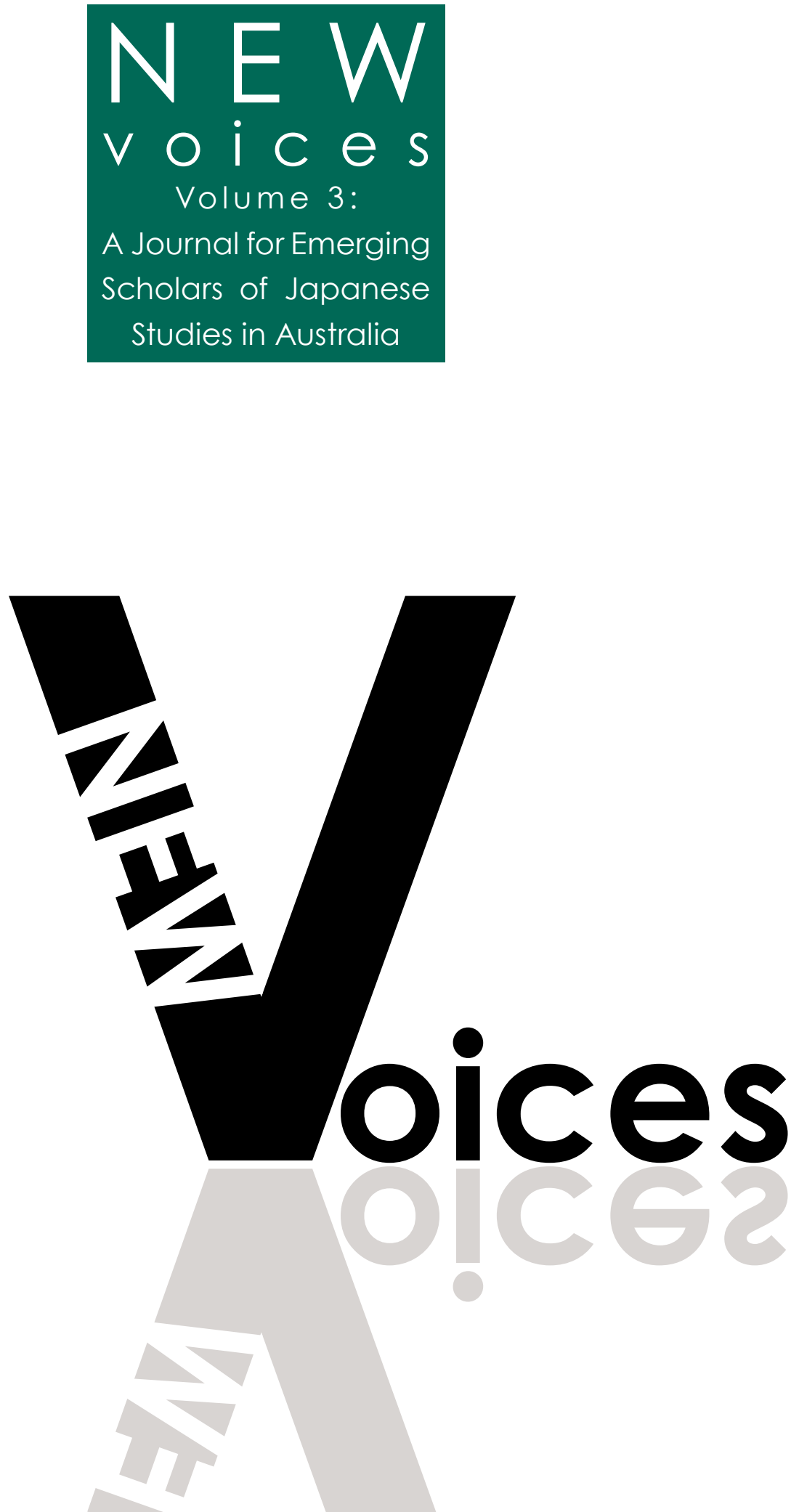
New Voices Volume 3:

A Journal for Emerging Scholars of Japanese Studies in Australia

The Japan Foundation, Sydney 


\section{New Voices}

Volume 3: A Journal for Emerging Scholars of Japanese Studies in Australia

New Voices Volume 3 is available for download from the New Voices website:

http://newvoices.org.au/

December 2009

(C) Copyright The Japan Foundation, Sydney, 2009

All material in New Voices is copyright. Copyright of each piece belongs to the author. Copyright of the collection belongs to the editors. Apart from any fair use as permitted under the Copyright Act 1968, no part may be reproduced without the prior permission of the author or editors.

The Japan Foundation, Sydney

Shop 23, Level 1 Chifley Plaza

2 Chifley Square

SYDNEY NSW 2000

Tel. (02) 82390055

Fax. (02) 92222168

www.jpf.org.au

\section{Editorial Advisory Board:}

Dr Tomoko Aoyama, University of Queensland

Professor William Coaldrake, University of Melbourne

Professor Nanette Gottlieb, University of Queensland

Dr Misuzu Hanihara-Chow, Macquarie University

Professor Tessa Morris-Suzuki, Australian National University

Dr Jun Ohashi, University of Melbourne

Dr Yuji Sone, Macquarie University

Dr Matthew Stavros, University of Sydney

Associate Professor Alison Tokita, Monash University

Ms Michie Akahane, Language Consultant, The Japan Foundation, Sydney

Ms Cathy Jonak, Language Consultant, The Japan Foundation, Sydney

Ms Mari Nobuoka, Language Consultant, The Japan Foundation, Sydney

\section{Editor, Volume 3}

Dr Christine de Matos, University of Wollongong

\section{Series Editors}

Wakao Koike, Deputy Director, The Japan Foundation, Sydney

Susan Wake, Program Coordinator, The Japan Foundation, Sydney

The views expressed in this journal are those of the authors, and do not necessarily coincide with those of the editors or members of the Editorial Advisory Board.

Japanese names are written surname first, except where the person concerned has adopted Anglo-European conventions. The long vowel sound in Japanese is indicated by a macron (e.g. kōtsū ), unless in common use without (e.g. Tokyo).

ISSN: 1833-5233

DOI: http://dx.doi.org/10.21159/nv.03

Printed in Australia by Gotham.

Cover Design by Warren Liang.

(C) Copyright The Japan Foundation, Sydney, 2009 


\section{Foreword}

New Voices was launched in December 2006 with the aim of supporting early career researchers and postgraduate students in Japanese studies to share their research interests with as wide an audience as possible.

In this third issue of New Voices, we have expanded the scope of the journal to showcase the work of both Honours and Masters graduates who completed their research at Australian Universities from $2006-2008$.

This year we have again been fortunate to receive a diverse range of submissions, demonstrating the quality and varied subject matter of Japanese studies research being conducted at universities across Australia. I hope that each volume of New Voices will encourage emerging Japanese studies scholars to continue their research and interest in Japan, while acting as a resource for general readers interested in early career Japanese studies scholarship in Australia.

I'd like to thank the following people for their assistance on this issue of New Voices: our Guest Editor, Dr Christine de Matos for her wonderful guidance and advice throughout the editorial and publication process; members of the editorial advisory board, for kindly offering their time and expertise to review the articles; Wakao Koike and Susan Wake for editorial assistance; and finally the 6 contributors and their supervisors without whose interest and enthusiasm this project would not have been possible.

\section{Tokiko Kiyota}

Director, The Japan Foundation, Sydney

December 2009 


\section{Contents}

Foreword $\quad$ iii

Tokiko Kiyota

Introduction $\quad$ vi

Christine de Matos

The Impact of the Telegraph on Anglo-Japanese Diplomacy during the Nineteenth Century

Jack Nicholls

Things That are Near Though Distant: Extramarital Affairs

in Heian-Period Japan

Matthew Grubits

Learners' Participation in Informal Japanese-English Internet Chat

Sarah Pasfield-Neofitou

Japanese wives in Japanese-Australian intermarriages

Jared Denman 
Thinking outside the Chinese Box: David Mitchell and Murakami Haruki's subversion of stereotypes about Japan

Chikako Nihei

Teaching culture in the Japanese language classroom: A NSW case study

Caroline Mahoney

Notes on Contributors 


\section{Introduction}

It was during the seasonal change from summer to autumn that I first landed in Tokyo as a naïve 21 year old, ready to embark on a working holiday adventure. I had no Japanese language skills, no knowledge of Japanese history or culture beyond western clichés and stereotypes, and 1000 yen in my pocket. When I think back to this time I am amazed at the courage (or was it denial and ignorance?) I must have had; I am even more surprised to remember the emotion I experienced, for as soon as I set foot in that great cosmopolitan city, I was in love. Somehow, I sensed something familiar and warm in the strange new sights and sounds around me, and gladly immersed myself in this new relationship I had found with Japan.

Over twenty years on, it gives me great pleasure to be part of the third edition of New Voices and to have the opportunity to work with emerging scholars who have been on their own journeys that enticed them into the field of Japanese Studies. Indeed, it is an exciting time to be part of Japanese and Asian Studies in Australia. The sector has been reinvigorated by a government that aims to make Australia more Asia-literate and able to participate more actively in this era of 'globalisation'. While it will be some time before we see the results, the National Asian Languages and Studies in Schools Program (NALSSP) and its associated funding opportunities offer much hope for Japanese language and studies to develop in Australian schools in terms of both quantity and quality through enhanced language teacher education, student scholarships and infrastructure development. One of the targets, for instance, is to have 12 per cent of Year 12 students fluent in an Asian language by 2020. Japan is one of the four areas targeted by the government, the others being China, Indonesia and Korea. ${ }^{1}$ This funding project should eventually flow over to benefit the tertiary education sector in terms of Japanese Studies undergraduate enrolments and higher research.

The language-studies nexus is an important issue within Japanese Studies, and one that dominated the 2009 Japanese Studies Association of Australia (JSAA) conference, held at the University of New South Wales from 13-16 July. For the first time, JSAA was combined with the International Conference on Japanese Language Education (ICJLE). ${ }^{2}$ Out of all the JSAA conferences I have personally attended over the years, it was the 2009 one that gave language research the greatest visibility. This heightened presence has been replicated in this issue of New Voices, where we received more submissions on language research than for previous editions. With the increasing emphasis on Asian languages in all education sectors, it is indeed timely

\begin{tabular}{ll}
\hline 1 & For more information: http://www.deewr.gov.au/Schooling/NALSSP/Pages/default.aspx. \\
2 & See conference website: http://jsaa-icjle2009.arts.unsw.edu.au/en/index.html.
\end{tabular} 
that New Voices engages with cutting edge research from emerging scholars in Japanese language acquisition and linguistics.

We have included two papers in the linguistic stream of the 2009 journal. The first paper is by Caroline Mahoney, who recently completed her Master of Teaching at the University of Sydney and is currently pursuing a $\mathrm{PhD}$ at Waseda. It is a qualitative case study that specifically investigates the implementation of Intercultural Language Learning (IcLL) by non-native speaking (NNS) Japanese language teachers in a New South Wales school. The best way to integrate culture into the language classroom to enhance student language acquisition is a hotly debated topic. While Mahoney's research uses a small data sample, it provides a useful model that could be further developed for a larger scale project, especially in order to understand the subjective experience of the teacher and their impact on cultural and language learning in the classroom.

The second linguistics paper is from Sarah Pasfield-Neofitou, who recently completed Honours in Japanese and Linguistics at Monash University. Pasfield-Neofitou has written a fascinating paper on what happens to language learning after the student leaves the classroom. She does this by investigating the way students learning Japanese as a foreign language use internet chat programs, such as MSN, to converse with native language speakers. Internet chat is a form of computer mediated communication (CMC) used in a student-controlled environment that presents both unique opportunities for further learning and complications, the latter including e-turn protocols, opportunities for distraction, and issues of power in the online intercultural environment. PasfieldNeofitou's research contains many important insights, and these are related to the role of technology in language education, student language acquisition outside of the classroom, and students' abilities to successfully negotiate a cross-cultural environment.

A theme that threads through this and a number of the other contributions is that of transnationalism. Pasfield-Neofitou has identified a transnational language learning environment mediated by technology - a long way from the old paper-based 'pen-pal' system. The paper by Jack Nicholls, who completed his Honours year at the University of Melbourne in 2008, has similar themes of the transnational, communication and technology, this time viewed through the discipline of history. His finely researched paper examines the impact of the telegraph on communication between British diplomats in Japan and their government in London. Nicholls focuses on three British diplomats: Sir Rutherford Alcock (1859-1864); Sir Harry Parkes (1865-1883); and Sir Ernest Satow (1895-1900). In particular, Nicholls analyses the impact of technology on the autonomy of these diplomats over time, and within the context of the changing place of Japan in British foreign policy, where it moved from being 'an exotic backwater' to a regional ally, the latter as marked by the 1902 Anglo-Japanese Alliance. 
The transnational theme continues in Chikako Nihei's literary research that compares the texts of David Mitchell and Murakami Haruki. Nihei is currently a Masters student at the University of Sydney, and she takes us on a journey through the novels of Mitchell and his attempts, as a westerner, to subvert orientalist western stereotypes and write about Japan 'as it is'. Mitchell has been influenced by the approach of Murakami, who successfully incorporates the many, often seemingly contradictory, faces of Japan into his own fictional works. Nihei's paper suggests a questioning of both nihonjinron and orientalism in literature on Japan and, through the comparative choice of Mitchell and Murakami, demonstrates the transnational path along which these questions interrogate, inform and contest each other.

Jared Denman, who completed Honours in 2008 at the University of Queensland where he is currently a PhD candidate, provides New Voices with some insights into the experiences of the Japanese diaspora in South East Queensland. Denman focuses on qualitative case studies of international marriages between Australian men and Japanese women. While a small data set is used, his research contributes to studies in migration, diaspora, cultural studies, multiculturalism and identity, and could be used to develop a larger research project in the future. In particular, Denman makes distinctions between the experiences of the so-called 'war brides' - Japanese women who married Australian soldiers during the Allied Occupation of Japan and migrated to Australia in the 1950s with these contemporary women. The contextual distinctions of their experiences could be summed up as the differences between multiculturalism and assimilation.

The final contribution comes from Matthew Grubits, who completed his Honours in 2008 at the University of Tasmania and is currently pursuing a Masters degree at the same institution. Grubits' historical paper examines the great classical texts of Sei Shōnagon, The Mother of Michitsuna and Murasaki Shikibu to reinterpret the role of the extramarital affair in aristocratic Heian society. This intriguing and convincing study defines sexual behaviour, as linked to other aspects of the Heian 'cult of beauty' such as poetry, emotion and dress, as an aesthetic act. Aestheticism also operated as a 'parameter' for appropriate behaviour - that is, those who had affairs that were not conducted according to aesthetic norms were socially penalised. Grubits' research effectively demonstrates how literary texts can be used as an historical source through which to interpret past society.

The collection in this third volume of New Voices may be small, but it nevertheless demonstrates the continuing vibrancy of Japanese Studies in Australia. It celebrates the diversity within Japanese Studies in terms of discipline areas (history, literature, linguistics and cultural studies), reflects the geographical spread of research (Sydney, Melbourne, Hobart and Brisbane) and contains content that traverses time, from Heian 
sexuality to contemporary Japanese women in Queensland. Therefore, my first thanks for this volume must go to the students, and to their supervisors, for sharing with us this collection of exciting new Honours and Masters research, and for undertaking the arduous task of taking a large and complex thesis and turning it into a smaller, coherent and polished stand-alone piece of writing.

Aside from the contributors, there are always many people who make a volume like this possible. All submitted papers are read by two or more expert members from the New Voices advisory board, and their advice and comments are invaluable to the contributors and for the editing process. Enormous thanks go to Dr Tomoko Aoyama, Professor William Coaldrake, Dr Misuzu Hanihara-Chow, Professor Tessa MorrisSuzuki, Dr Matthew Stavros, Associate Professor Alison Tokita, Dr Jun Ohashi, Professor Nanette Gottlieb, Dr Yuji Sone, Cathy Jonak, Michie Akahane and Mari Nobuoka for giving up time from their busy schedules to support this volume of New Voices. Thanks also to the tireless Wakao Koike for his continuing dedication to and support of new research on Japan in Australia, and to the Japan Foundation for supporting the New Voices project and giving me this opportunity to be part of the third volume. The final editing of a volume can be difficult and time-consuming, and this task has been competently undertaken by the ever-diligent and enthusiastic Susan Wake. Finally, I would like to thank my predecessors, Yuji Sone and Matthew Stavros, for setting such a fine editing standard for me to (attempt to) follow.

We all hope that you enjoy the third volume of New Voices and feel reinvigorated by this selection of new research by emerging scholars in Australia. Indeed, with a changed environment that supports the growth of an Asia literate nation, the future of Japanese Studies in Australia looks brighter than it has for some time. Through an expanded secondary education Japanese language and studies program, hopefully it will not necessarily take a random event, like being clueless, penniless and fascinated in Tokyo, to inspire current and future students to enter the field of Japanese Studies.

Dr Christine de Matos

University of Wollongong

Editor, New Voices, vol. 3 


\section{On the Journal's Format}

All successful submissions to this issue of New Voices are published online and are universally accessible at: http://www.jpf.org.au/newvoices. Several of the essays, however, were chosen by the editor and advisory board to also be published in a physical journal format, which was distributed to universities and libraries across Australia and to the Japan Foundation's 22 overseas branch offices. The selection of these essays was based not only on quality but on an attempt to provide readers with representative examples of Honours and Masters scholarship in several disciplines at a variety of Australian universities. 


\title{
The Impact of the Telegraph on Anglo-Japanese Diplomacy during the Nineteenth Century
}

\author{
Jack Nicholls \\ The University of Melbourne
}

\begin{abstract}
In our age of high-speed communication, it is easy to underestimate how vast the distance between Britain and Japan really is. At a time when it took over four months for letters to cross from Japan to Britain and back, the first British diplomats posted there were almost completely isolated by their remoteness. The British Ministers to Japan were thus forced to rely on their own judgement in carrying out their allotted task of nurturing British commerce, with occasionally disastrous consequences. This isolation was ended at a stroke in 1870, when Japan was connected to the globe-spanning telegraph network, and the British could send messages via the wire between London and Tokyo in a matter of hours rather than months.
\end{abstract}

This article explores the degree to which the everyday business of a British envoy in Japan was actually changed by the introduction of the telegraph, and asks whether the availability of a technology is enough, in itself, to change society. To answer this question, I look at the careers of the three most distinguished nineteenth-century British diplomats in Japan: Sir Rutherford Alcock (1859-1864), Sir Harry Parkes (18651883) and Sir Ernest Mason Satow (1895-1900).

\section{Keywords}

Britain, diplomacy, telegraph, isolation, technological Determinism

\section{Introduction}

The introduction of the electric telegraph did more to change the practice of international diplomacy than any other innovation in modern history. Prior to the telegraph, diplomats were more than mere mouthpieces for their governments; they were guaranteed a degree of autonomy by way of their isolation. Representatives had to rely on their own judgements and were often forced by events to make significant policy decisions. The more remote from the home government their posts were, the more self-sufficient foreign legations had to be, as well-meaning advice from the homeland could be painfully out of date by the time it reached them. 
In the nineteenth century, few postings were more remote for a British envoy than Japan. Vast gulfs of language, culture and distance separated Imperial Japan from Whitehall, home of Her Majesty's Government. The initial British Ministers in Japan effectively acted with complete independence, as the Foreign Ministry had scant knowledge about the remote Asian country and its instructions took two to three months to arrive in Edo. However, by 1871 the telegraph network had spread to Japan, with wires running unbroken from London to Nagasaki. While the Foreign Office still had a much fuzzier understanding of Japanese politics than the men on the spot, it could now transmit instructions almost instantaneously. ${ }^{1}$ In theory this should have slashed the independence of the British minister. However, as this article will show, although telegrams became an integral part of consular business, the relationship between the Foreign Office and the Minister in Japan remained largely unchanged until the politics of the Anglo-Japanese relationship shifted at the end of the century.

\section{The History of the Telegraph}

The concept of the electric telegraph evolved in the early nineteenth century from previous experiments using masts and flags to transmit information faster than could mounted messengers. ${ }^{2}$ Building on eighteenth-century experiments with electricity, the first telegraphs were designed in the 1840s. They consisted of an electromagnet connected by wires to a marking instrument, such as dials or needles, at the other end. By pressing down to connect the electromagnet to the circuit, a telegrapher would send bursts of current through the line that would then be received and interpreted. Once the significance and potential of the electric telegraph had been grasped around 1845, networks swiftly sprang up across Europe. ${ }^{3}$ The telegraph was neither instantaneous nor infallible; messages would often be garbled or delayed. Nevertheless it revolutionised finance markets, journalism, military operations, espionage and diplomacy: all areas where information was power and quicker access to it gave one an edge.

Twenty years on, the telegraph networks had spread to East Asia. For strategic reasons, Britain required a line to India, while Russia needed to link its Pacific territories with the west. Commercial pressures then drove the wires further east, and competition between Russian- and British-backed firms saw telegraph lines from Siberia reach China and Japan in $1870 .{ }^{4}$ While the Chinese government futilely resisted the technology, in

\footnotetext{
1 And they were men: women were barred from the diplomatic service until 1946. The term 'man on the spot' was coined by John S. Galbraith in an essay analysing how the frontiers of the British Empire were pushed forward in the nineteenth century through the actions of Governors who saw military force as the answer to their problems of a 'turbulent frontier'. See John S. Galbraith, 'The "Turbulent Frontier"', pp. 150-168.

2 Headrick, When Information Came of Age, pp. 194-195.

Ibid., pp. 54-56.

Ahvenainen, The Far Eastern Telegraphs, p. 207.
} 
Japan the new Meiji regime encouraged Western-style development. ${ }^{5}$ Meanwhile, the British Foreign Office had finally accepted the worth of the new technology and by the end of the 1860s the Government had installed private lines directly to the Foreign Office in Whitehall. ${ }^{6}$ The adoption of the telegraph by the British diplomatic service therefore coincided with the connecting of Japan to the world communications network, marking 1870 as the beginning of a new era in British Far Eastern diplomacy.

\section{British Diplomacy}

While diplomacy was an age-old practice, its methods had steadily evolved for centuries prior to the telegraph. Although Britain's seafaring power made the country a successful trading nation by the eighteenth century, its diplomatic relations were then confined to Europe and lacked a formal structure. When the British began to graduate from trade to conquest, their activities in far-flung corners of the world necessitated more rigorous government monitoring. Thus, in 1782 the Foreign Office was formed, under the aegis of the Secretary of State for Foreign Affairs (the Foreign Secretary). He oversaw a network of British diplomats who conducted negotiations with foreign powers and sent back official reports - despatches - on local affairs.

The conduct of diplomatic relations within Europe was standardised at the

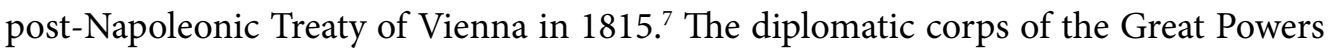
were divided into three ranks: Ambassador Extraordinary and Plenipotentiary, Envoy Extraordinary and Minister Plenipotentiary, and Chargé d'Affaires. Three years later an intermediate 'Resident Minister' position was also recognised. ${ }^{8}$ The rank of diplomatic representative sent overseas depended on the perceived importance of that posting, but most capitals would have an envoy with 'plenipotentiary' powers allowing them to speak, and even sign binding documents, for a Sovereign. ${ }^{9}$ These ministers and ambassadors abroad communicated with Whitehall via despatches: each one written in longhand, numbered and sent home by mail or messenger. ${ }^{10}$

This restructured Diplomatic Corps was dealing with an ever-expanding British presence in Asia. The subjugation of India continued apace, and the First Opium

\footnotetext{
5 There were some Chinese officials who argued against a conservative approach of course, notably the modernising Li Hongzhang, but their views did not prevail. See Erik Baark, Lightning Wires, pp. 73-74.

6 Ibid., p. 148.

7 Article 1 of the Vienna Règlement sur le rang entre les agents diplomatiques reads as follows:

Art. 1. - Les employés diplomatiques sont partagés en trois classes: celle des ambassadeurs, légats ou nonces; celle des envoyés, ministres ou autres, accrédités auprès des souverains; celle des chargés d’affaires, accrédités auprès des ministres chargés du portefeuille des affairs étrangères. Satow, A Guide to Diplomatic Practice, p. 149.

8 Resident Ministers were inferior to Ministers Plenipotentiary and above Chargés d'Affaires, and were formally recognised at the Conference of Aix-laChapelle in 1818. Satow, A Guide to Diplomatic Practice, p. 156.

9 Jones, The British Diplomatic Service, p. 99.

10 Ibid., p. 119.
} 
War (1839-1843) brought Hong Kong under British rule and forced the opening of certain coastal Chinese cities to British citizens. The period marked the high-point of a moralistic, interventionist foreign policy (sometimes called 'gunboat diplomacy') that saw the threat of British military force deployed to advance commercial and strategic interests outside Europe. ${ }^{11}$ As often as not, this aggression was spearheaded by men on the spot, rather than directed from Whitehall, and 'wars might be fought and the issue decided before news of their outbreak reached London.' ${ }^{12}$ To non-European peoples, the British could appear belligerent and condescending, as the Japanese were to observe at firsthand in the nineteenth century.

\section{Literature Review}

Diplomatic history is a well-mined field, but by and large it ignores the impact of communications technology, the subject of this article. There are, however, some relevant texts. Raymond Jones' The British Diplomatic Service analyses the degree to which the telegraph changed diplomacy, and while Jones considers its impact colossal, he argues that issues of expense hindered its effectiveness for Westerners in East Asia; a position which my own research has borne out. ${ }^{13}$ As for the relationship between the Foreign Office and the men on the spot, John Galbraith wrote an outstanding and influential article, although it ignores Japan and contains only cursory mention of the telegraph. ${ }^{14}$ The most relevant study of the telegraph's introduction to Asia came from Jorma Ahvenainen in his 1981 publication The Far Eastern Telegraphs, a thorough history of the competing companies which laid lines into China and Japan. ${ }^{15}$

However, a detailed examination of the telegraph's impact on diplomacy had to wait until 2003, when David Paull Nickles released Under the Wire. ${ }^{16}$ The book chronicles how telegraphy shook up diplomacy, and the methods by which diplomats manipulated the system to their own advantage, concluding that in the end the new technology devastated the autonomy of the man on the spot. In contrast, Daniel Headrick, in his book The Invisible Weapon, holds that telegraphy did not dramatically increase government control on the imperial fringes due to issues of cost, garbling of messages and overly independent officials abroad. ${ }^{17}$

The belief that the telegraph would have automatically diminished the role of

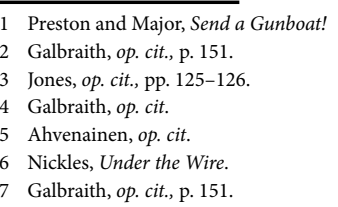


diplomats is a form of 'technological determinism'; a theory that technological change fundamentally shapes events and behaviour. ${ }^{18}$ For my case, I believe that the technology of the telegraph potentially reduced Ministers to puppets of their respective Foreign Services, but this was forestalled by the problems inherent in long-distance telegraphy. While the telegraph certainly had an immediate effect on the position of diplomats on the spot, it was not until their governments had enough incentive to prioritise the AngloJapanese relationship that they saw their policy-making capabilities truly curtailed.

\section{Sir Rutherford Alcock: 1859-1864}

From the seventeenth to the nineteenth century, Japan was a stable and insular state in which lip-service was paid to the Japanese Emperors, but the country was actually governed by the shogun, whose power stemmed from force. The shogun oversaw a military government known as the bakufu, and regional power was held by powerful feudal rulers called daimyo. Since the 1630s, the bakufu had successfully closed Japan to foreign trade and negotiation. It was forbidden, on pain of death, for Japanese citizens to go abroad, Christianity was outlawed and foreign vessels were restricted to Nagasaki. ${ }^{19}$ The Dutch were the only Westerners permitted to conduct trade with the Japanese, and only then on Deshima, an island in the Nagasaki bay. ${ }^{20}$

Yet the world was changing. By the first decades of the nineteenth century, Qing China was being increasingly penetrated by Western economic interests, and this came to a head in the First Opium War (1839-1842) when Britain humiliated the Chinese. From then, it did not take long for the blow to fall on Japan. In 1853, Commodore Matthew Perry of the US Navy arrived in the Uraga Channel with four state-of-theart steam-ships. ${ }^{21}$ Faced with this threat, the bakufu was blackmailed into signing the Treaty of Kanagawa in 1854, opening two ports to foreign trade. ${ }^{22}$ The British quickly followed America's lead, and the same year Japan signed a 'Convention for Regulating the Admission of British Ships into the Ports of Japan', followed in 1858 by a more detailed 'Treaty of Peace, Friendship, and Commerce between Her Majesty and the Tycoon of Japan.' ${ }^{23}$ This treaty emphasised 'commercial intercourse' between the two island states, although not on an equal footing. British citizens were to be immune from prosecution by Japanese authorities and given immediate commercial access to several

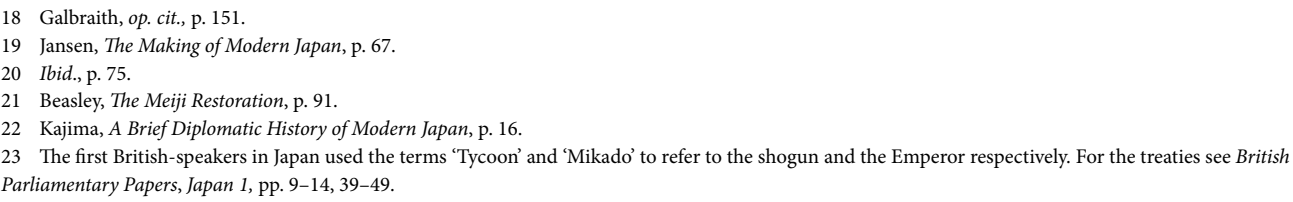


port towns, which came to be known as 'treaty ports. ${ }^{24}$ Foreigners were also allowed a limited presence in Edo and Osaka. Finally, the treaty allowed a British envoy to take up residence in the country, marking the beginning of modern Anglo-Japanese diplomacy in 1858. The treaty was, of course, negotiated by a diplomat with plenipotentiary powers, Lord Elgin. ${ }^{25}$

Sir Rutherford Alcock (1809-1897) was the man chosen as Britain's pioneering representative in Japan. A medical doctor who had joined the diplomatic service, Alcock had served fifteen years as Consul in China. ${ }^{26}$ In comparison to the cosmopolitan ports of China, Japan was a lonely position for a British gentleman: Alcock had only five staff with him in Edo, and he held a low opinion of the British merchants who plied their trade locally. These hardships were partially ameliorated by Alcock's annual salary: a generous $£ 2000$ in $1860 .^{27}$ Meanwhile, a gulf of language separated Alcock from his Japanese hosts. Until interpreters like the young Ernest Satow could be trained, exchanges between the British and Japanese had to be first rendered into Dutch before translation into the other language. Isolated by the language barrier and his distance from Britain, Alcock had to be guided by the general instructions he had received before his arrival: to uphold Britain's newly won Treaty rights and encourage the expansion of British commerce in Japan. ${ }^{28}$

As was his duty, Alcock immediately began sending despatches back to John Russell (1792-1878), the Foreign Secretary. Russell replied when able, but correspondence between him and Alcock was decidedly one-sided. Russell was responsible for British ministers across the world, most in more immediately important outposts than Japan, where British trade was still in its infancy. Even if he had had the time, Russell was hampered by his ignorance of Japanese customs and politics. Unsurprisingly then, Alcock received little meaningful input from home in his first years at Edo. ${ }^{29}$

Given his isolation, Alcock was forced to improvise and sometimes conduct policy on the fly. This was illustrated within two months of his landing in Japan. Alcock had arrived in the country with the title of Resident Minister, lacking full authority to make policy in the name of Queen Victoria. Realising the importance with which the Japanese regarded protocol, and discovering that his American counterpart

\footnotetext{
24 The treaty opened the ports of Hakodadi [sic], Kanagawa and Nagasaki on 1 July 1859, and declared that 'Nee-e-gata' and 'Hiogo' (Kōbe) would be opened 1 January 1863. Checkland, Britain's Encounter with Meiji Japan, p. 5.

25 Fox, Britain and Japan, pp. 42-43.

26 Cortazzi, British Envoys in Japan, p. 9.

27 Alcock to Russell, Despatch 41, Inclosure A, 'Statements of the Expenses of Her Majesty's Diplomatic and Consular Establishment in Japan', 13 July 1860,

in Bourne and Watt, British Documents on Foreign Affairs, pp. 8-11.

28 Cortazzi, op. cit., p. 14.

29 Cortazzi has described Russell's despatches in this period as 'inconsistent and weak', Cortazzi, op. cit., p. 37.
} 
was a Minister Plenipotentiary, Alcock awarded himself a promotion to Minister Plenipotentiary and Consul-General without waiting for confirmation from Whitehall. He penned an explanation home, explaining his belief that time had been of the essence:

[I] Felt too strongly, on the spot, the critical nature of our first relations with Japan, and the great importance of taking a position which may enable the British Agent to make head against the hostile elements in full action and keep them in check. ${ }^{30}$

The promotion allowed Alcock to negotiate directly with the bakufu's Ministers for Foreign Affairs, and Alcock stated his willingness to resign if Her Majesty's Government felt that he had overstepped himself, although he urged them to retain the new rank for his successor. In the circumstances, Alcock no doubt made the right decision. Nonetheless, it was an extraordinary illustration of the power an envoy on the periphery of the British Empire could have, for lack of any alternatives. The Foreign Office could hardly countermand the decision, four months after the Japanese had begun dealing with the new arrangement. Regardless, there is no evidence that Russell was perturbed by these events. He wrote back assuring Alcock that, 'The Queen has been graciously pleased to confer upon you the rank of Her Majesty's Envoy Extraordinary and Minister Plenipotentiary in Japan. ${ }^{31}$

The complexities of the Japanese situation meant that Alcock was not always able to follow his instructions to the letter. The origin of such divergences, when they arose, lay in the difficulties Alcock had in carrying out his government's policy in a country run by a passive-aggressive bakufu. As Russell wrote to Alcock, Her Majesty's Government wanted 'to maintain and, if possible, enlarge [trade with Japan], and you are to preserve undiminished the reputation of the British name' but it had 'no desire to quarrel with Japan. ${ }^{32}$ The value of Japanese trade was not worth the vast expense of fighting a war with the country. This left Alcock with a dilemma. He needed the potential threat of force to wring concessions from the bakufu, but he did not want to begin a conflict at a time when Britain was already battling China in a second Opium War (1856-1860). It was a delicate line, and in the eyes of the Foreign Secretary he came dangerously close to crossing it in late 1859. Faced with bureaucratic obfuscation, Japanese evasion of Treaty responsibilities and assassination attempts on the legation, an infuriated Alcock wrote to the Japanese Ministers for Foreign Affairs insisting on a meeting, warning that:

30 Alcock to Russell, 10 August 1859, no. 12 of 'Correspondence with Her Majesty's Envoy Extraordinary and Minister Plenipotentiary in Japan', 1860(2648) LXIX, p. 28, in British Parliamentary Papers, Japan 1, p. 84.

31 Russell to Alcock, 8 December 1859, no. 25 of 'Correspondence with Her Majesty's Envoy Extraordinary and Minister Plenipotentiary in Japan', 1860(2648)LXIX, pp. 58-59, in British Parliamentary Papers, Japan 1, pp. 114-115.

32 Russell to Alcock, 23 November 1861, no.13 of 'Correspondence Respecting Affairs in Japan, July to November 1861', 1862(2929)LXIV, pp. 72-73, in British Parliamentary Papers, Japan 1, pp. 366-367; Russell to Alcock, 8 April 1861, no. 5 of 'Correspondence Respecting Affairs in Japan, March and April, 1861', 1861(2829)LXVI, pp. 11-12, in British Parliamentary Papers, Japan 1, pp. 213-214. 
What I have to communicate is of such grave importance that on the result of our interview may depend the continuance of amicable relations between the two countries $\ldots$ on its result may ultimately depend a state of peace and war between the two countries. $^{33}$

Lord Russell received a copy of Alcock's letter a few months later, and was clearly worried by it. He wrote back explaining the position of Her Majesty's Government, and the problems engendered by Alcock's attitude:

Her Majesty's Government approve your general conduct; but it were to be wished that you had not threatened war. If the grievances are not redressed and war is not made, the character of the British Government is in some degree impaired; if war is made to enforce the observance of a Commercial Treaty, we run the risk of engaging in protracted hostilities, and of earning a reputation for quarrelling with every nation in the East.

... Our intercourse is but newly begun: it should not be inaugurated by war. ${ }^{34}$

By the standards of diplomatic language, this was a sharp rebuke. The episode was an example of the Minister having to take actions which would have been unforeseen when he was appointed, actions that could cause concern in the conservative bureaucracy of Whitehall. The most dramatic example of this was still to come, near the end of Alcock's final term as Minister to Japan. Indeed, Alcock's actions were responsible for ending his position in that country.

On 25 June 1863 an American trading vessel was fired upon by Japanese warships in the Shimonoseki Straits that divide Kyūshū from Honshū. ${ }^{35}$ The Straits were controlled by the powerful Chōshū clan, aligned with the anti-foreign clique within the bakufu, and for a year afterwards they were effectively closed to commerce. Alcock believed that if he was going to fulfil his duty of maintaining British trade, he would have to take action. So, on 1 September 1864, with the blessing of the bakufu, a multinational force of warships and marines organised by Alcock appeared in the Straits to destroy the Chōshū gun batteries. ${ }^{36}$ The Chōshū defences were shattered in exchange for light Western losses, and the Japanese surrendered on 8 September. ${ }^{37}$

33 Alcock to the Japanese Ministers for Foreign Affairs, 6 December 1859, inclosure 2 in no. 12 of 'Correspondence with Her Majesty's Envoy Extraordinary and Minister Plenipotentiary in Japan', 1860(2648)91, in British Parliamentary Papers, Japan 1, p. 147.

34 Russell to Alcock, 28 February 1860, no. 44 of 'Correspondence of Sir Rutherford Alcock, Minister Plenipotentiary to Japan', 1860(2648)LXIX, p. 98, in

British Parliamentary Papers, Japan 1, p. 154.

35 Fox, op. cit., p. 113.

36 Satow, A Diplomat in Japan, pp. 102-115.

37 Ibid., pp. 114-116. 
Despite the strategic success of this mission, it sparked a furore in London. Upon receiving word of Alcock's intentions in August, Lord Russell wrote a response recalling the Minister to London 'to explain the actual situation of affairs, and confer with Her Majesty's Government as to the measures to be taken. ${ }^{38}$ A few days later he again cautioned against military action. ${ }^{39}$

Quite unaware of Russell's dismay, Alcock launched the Shimonoseki assault and wrote back a cheery summary of the events, stating 'I would fain hope the course I have taken will have been approved even before the result could be known' and that 'the policy I am now directed to follow, as summed up in four heads by your Lordship, it has been my fortune to anticipate in a great degree, if not in every particular. ${ }^{40}$ Russell received the lengthy despatch on 27 November and understanding the affair more clearly responded in a much friendlier tone that 'Your despatch of the $28^{\text {th }}$ of September is a successful vindication of the policy you have pursued' and that given the circumstances Alcock had made the correct decision. ${ }^{41}$

At that stage, Alcock had only received Russell's first despatch and it was now his turn to be unhappy, as were his staff. ${ }^{42}$ As ordered, he arranged to voyage back to England, but before departing produced one final despatch eloquently defending his policy against what he saw as Russell's 'censure and condemnation'. ${ }^{43}$ He pointed out the impossibility of fulfilling his dual instructions of defending British interests and taking no potentially inflammatory action, especially against 'Asiatics' who 'respect[ed] only force. ${ }^{44}$ In his letter, Alcock summed up beautifully the tyranny of distance that shaped his predicament:

It could be no reproach to the members of the Cabinet at 14,000 miles distance, to be deceived as to the course most likely to conduce to the desired end; but it would have been a great disgrace to Her Majesty's Representative on the spot, if he had failed to discern the true bearing of events as they passed under his eye ... In doing this, I undoubtedly employed the means placed at my disposal for that end, in a way that my recent instructions seem to condemn. But this I attribute entirely to the difficulty of

38 Russell to Alcock, 8 August 1864, no. 45 of 'Correspondence Respecting Affairs in Japan', 1864(3303)LXVI, p. 54, in British Parliamentary Papers, Japan 2, p. 212.

39 Russell to Alcock, 25 August 1864, no. 50 of 'Correspondence Respecting Affairs in Japan', 1864(3303)LXVI, p. 57, in British Parliamentary Papers, Japan 2, p. 215.

40 Alcock to Russell, 28 September 1864, no. 67 of 'Correspondence Respecting Affairs in Japan', 1864(3303)LXVI, pp. 119-122, in British Parliamentary Papers, Japan 2, pp. 277-280.

41 Russell to Alcock, 2 December 1864, no. 71 of 'Correspondence Respecting Affairs in Japan', 1864(3303)LXVI, pp. 127-128, in British Parliamentary Papers, Japan 2, pp. 285-286.

42 In his memoirs, Satow wrote that Russell's despatch amounted to 'A censure upon his [Alcock's] conduct', both unfair and irrelevant, Satow, A Diplomat in Japan, p. 134.

43 Alcock to Russell, 19 November 1864, no. 88 of 'Correspondence Respecting Affairs in Japan', 1864(3303)LXVI, pp. 148-155, in British Parliamentary Papers, Japan 2, pp. 307-313.

44 Ibid., p. 312. 
measuring with accuracy, at such a distance, the real bearing of the action taken, and the progress of events which led to it ...

... I would rather, and I am satisfied so would your Lordship in a similar situation, incur temporary censure for a seeming departure from instructions dictated in ignorance of the actual circumstances, and at an interval of several months, by which the real object of Her Majesty's Government should be secured, than claim merit for a blind obedience, the result of which must be failure and disaster. ${ }^{45}$

Having missed Russell's apologetic despatch of 2 December, Alcock then endured an undoubtedly stressful voyage of many weeks, only to arrive back in London to be feted for his 'meritorious services' in Japan. Indeed, Russell rather unconvincingly denied that there had ever been any implication that Alcock was being censured or fired. ${ }^{46}$ Despite this, Alcock was never to return to Japan, instead being promoted to the position of Minister at Beijing. ${ }^{47}$

Thus, Alcock's tenure in Japan drew to a close in 1864, shortly before great upheavals were set to take place there. In hindsight, the correspondence between Alcock and Russell resembles a comedy of errors, but it is an indication of the serious problems Britain faced in administering her interests across the globe. While Russell and Alcock shared the same goals when it came to Japan, their situations gave them different outlooks as to the best means to achieve them. For Russell and the Foreign Office, Japan was but one minor interest in a globe-spanning Empire, easily overshadowed during a period of crisis in China. ${ }^{48}$ On the other hand, Alcock's career and reputation rested on his success with the Japanese. Given this, and the pressures of his circumstances, Alcock was perhaps prepared to go further than the Foreign Office had envisioned would be necessary. Had he access to a telegraph, Alcock's career might have proceeded quite differently - which brings us to his successor.

\section{Sir Harry Parkes: 1865-1883}

Sir Harry Parkes (1828-1885) arrived in Japan in April 1865, only thirty-eight years of age, and was to hold the position of Minister Plenipotentiary for an impressive eighteen years, until he was transferred to Beijing in 1883 . He had therefore already

$45 \quad$ Ibid., p. 311.

46 Russell to Alcock, 31 January 1865, no. 89 of 'Correspondence Respecting Affairs in Japan', 1864(3303)LXVI, pp. 155-156, in British Parliamentary Papers, Japan 2, pp. 313-314; again, Satow disagreed, pointing out in his account of the affair that 'an invitation to return home is equivalent to the removal of a diplomatic officer from his employment', in Satow, A Diplomat in Japan, p. 134.

47 Satow, A Diplomat in Japan, p. 141.

48 Japan was not even officially recognised in the Foreign Office organisation until 1865, and even then it was hidden away with China and Siam in the 'American Department', Steeds and Nish, China, Japan and Nineteenth Century Britain, pp. 12-13. 
been stationed in Japan for five years by the time that a direct telegraphic connection with Europe was installed. Parkes' career thus straddles the threshold between isolation and connectedness in international diplomacy. By studying Parkes, we can see the degree to which the business of a man on the spot was immediately changed by this new technology.

Parkes was eminently well-suited to the post of Minister in Japan by his experience, if not necessarily by his personality, having served previously as consul in China, including a period under Sir Rutherford Alcock in the 1840s. His work in China was eventful, as he played a leading role in the lorcha Arrow incident that provoked the Second Opium War, and was held captive by the Chinese in the final weeks of that conflict. ${ }^{49}$ His zealotry may have grated on Japanese sensibilities, but nobody could deny that Parkes was a man of action, not given to the doubts that had plagued Alcock.

When Parkes arrived in Japan, he was guided by a set of instructions from Lord Russell in the same mould as those sent to Alcock: to 'pursue a firm but conciliatory policy toward the Tycoon and his Ministers. ${ }^{50}$ Working from these guidelines Parkes continued business much as usual in Japan, but events were to overtake him. In November 1867, the shogun formally surrendered his powers to the Emperor, to the dismay of his vassal daimyo. By January 1868, simmering hostility between these supporters of the shogunate and those of the Emperor exploded into civil war. Parkes kept a low profile, and by mid-1869, the fighting was over and the progressive forces of the Emperor had triumphed..$^{51}$ Political change had come to Japan, and with it, technological change too. That year, the first telegraph line in Japan was raised between Tokyo, the recently renamed capital, and Yokohama; encouraged by the new Government which saw technology as the key to strengthening the country to match Europe. ${ }^{52}$ Japan was entering a new era of modernisation, and Parkes was an eager advocate of such a course. He wrote to the new Foreign Secretary, the Earl of Clarendon:

I have had frequent opportunities of discussing with the Mikado's Government the desirability of introducing Railways and Telegraphs into Japan. It is essential ... that improved means of communication should be provided. ${ }^{53}$

49 Hurd, The Arrow War.

50 Russell to Parkes, 8 April 1865, no. 8 of 'Correspondence Respecting Affairs in Japan, 1865-1866', 1866(3615)LXXVI, pp. 8-9, in British Parliamentary Papers, Japan 2, pp. 380-381.

51 Hane, Modern Japan, p. 81

52 See FO 46/125, Unknown (Japanese) author, no 72, insert no. 1, 'An Essay on the Introduction of Railways and Telegraphs', March 1870, enclosed in Parkes to Clarendon, no. 65, 21 April 1870.

53 FO 46/125, Parkes to Clarendon, no. 65, 21 April 1870. 
Back in England on leave in 1872, Parkes repeated his sentiments in a statement before a committee of the House of Commons, where he reported that 'a very considerable portion of my time and my duties' was taken up by encouraging the Japanese government in constructing railways and telegraphs. ${ }^{54}$ The questions the committee went on to ask Parkes about the Far East were of a very basic nature, and showed how ignorant most of the British government remained about the region. ${ }^{55}$ Even with a telegraphic connection in place, few in Britain had the interest or capacity to cable Parkes relevant instructions about his post.

Parkes' labours bore fruit in 1871 when a submarine cable was laid between Nagasaki and Shanghai by the Great Northern Telegraph Company. ${ }^{56}$ This allowed Parkes, in theory, to refer queries home and get a response within hours. There is little indication, however, that Parkes' role was substantially changed by this dramatic modernisation. The evidence of the Foreign Office files suggests that telegraphing was an expensive, bureaucratic nightmare. Each telegram received by the Foreign Office spawned a series of internal memos regarding compensation for the sender; and the

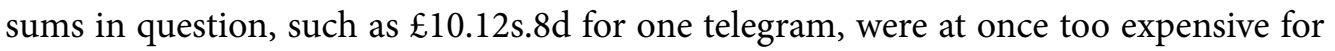
everyday business, and too minor to be worth the trouble they caused ${ }^{57}$ It is unsurprising that the Treasury discouraged frivolous telegraphing and reminded diplomats that telegrams required economy. ${ }^{58}$

Concision was a virtue, but telegrams could become so compressed as to make understanding difficult..$^{59}$ To protect against espionage, telegrams were usually encoded as well, and the resulting nonsense words were more liable to mistakes in transfer by telegraph operators, or erroneous decipherment. ${ }^{60}$

Given these myriad potential problems, it is unsurprising that a diplomat of the old Palmerstonian mould did not embrace the telegraph. The vast majority of Parkes' business was still conducted through handwritten despatches. Yet while the telegraph may not have revolutionised Parkes' day-to-day work, it did prove decisive in curtailing an inflammatory plan of his to annex an island off the south coast of Korea.

\footnotetext{
54 Daniels, Sir Harry Parkes, p. 127.

55 Ibid., pp. 125-130.

56 Great Northern, a Danish firm backed by Russian capital, was one of the two major telegraph companies then operating in the Far East. Eiichi Itoh, 'The Danish Monopoly on Telegraph in Japan', p. 89.

57 FO 46/101, Rogers to the Under-Secretary of State, 6 March 1868; FO 46/102, Rogers to Hammond, 2 May 1868; FO 46/103, Treasury Chambers to the Under-Secretary of State, 2 November 1868; FO 46/103, Draft, 21 November 1868; FO 46/103, Treasury Chambers to the Under-Secretary of State, 2 December 2 1868; FO 46/101, Rogers to the Under-Secretary of State, 6 March 1868.

58 British Parliamentary Papers, 1859 (Session 1) 14, 115; Circular, 25 September 1858, in Jones, op. cit., p. 123; Steeds and Nish, China, Japan and Nineteenth-Century Britain, p. 13.

59 Nickles, Under the Wire, p. 175.

60 For example, see FO 46/192, Parkes to Derby, telegram, 20 July 1875. The Foreign Office files contain three versions of the important telegraph, deciphered by different branches of government. While they are more or less the same, each version contains mistranslations and missing words, indicating the difficulties with telegram decipherment in this period.
} 
Parkes' scheme was devised in July 1875 at a time when the Meiji government was starting to eye a bigger role for Japan in regional politics, notably in Korea, which remained closed to foreign trade just as Japan had been a quarter of a century earlier. Meanwhile, the steady expansion of the Russian empire had taken it to the Korean border, and there were rumours of conflict in the near future. ${ }^{61}$ In what Gordon Daniels described as an 'overreaction', Parkes began to fear an impending partitioning of Korea between Russia and Japan, if not other Powers; a similar situation to that occurring in China. ${ }^{62}$ Concerned that this would strengthen Britain's rivals and destabilise the East, Parkes dashed off an enciphered telegram to the Foreign Office, warning:

[d]ifficulties are rising between Japan and Korea, and rupture of relations appears probable. An understanding between Russia and Japan as to attack on Corea is reported. Japanese vessels of war are already engaged in surveying East Coast of Corea. A large German corvette is also sweeping the West Coast with a view, as it is believed, to occupation. ${ }^{63}$

In light of the 'highly probable eventualities' (a conflict), Parkes urged that British naval forces stationed around Japan immediately occupy Port Hamilton (Geomun-Do to its inhabitants): a natural harbour in the Korea Strait, and thus Korean territory. ${ }^{64}$ Parkes also claimed to have the support of the local British admiral for this plan. ${ }^{65}$

Parkes' proposal, tantamount to declaring war on the commercially unimportant state of Korea, was not received warmly back in London. The notes scrawled by Lord Derby (Foreign Secretary 1866-1868) regarding the decrypted telegram show that he was not persuaded by Parkes' counsel, but the Foreign Office dutifully telegraphed Berlin and St Petersburg to see if the British ministers there had heard anything to support Parkes' allegations. ${ }^{66}$ The replies stated that there were no rumours of such an action, nor any hint of deteriorating relations with the Koreans. ${ }^{67}$

Unsurprisingly, Parkes was ordered to abandon his plan, and indeed no portioning of Korea eventuated. Did the telegraph thus avert an unnecessary conflict that could have sparked a scramble for Korea? The tone of Parkes' telegram of 20 July, which warned that Port Hamilton might have been already annexed by another Power

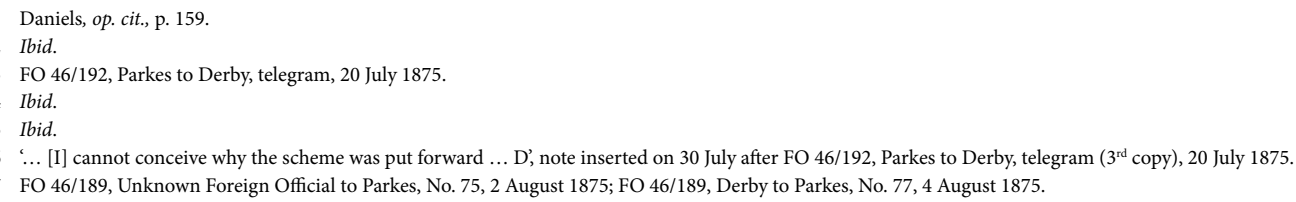


and advocated action within the week, made it clear that the Minister considered the operation to be immediately necessary. ${ }^{68}$ This raises the question of whether, had he lacked access to the telegraph, Parkes would have stuck to the letter of his instructions and not used force to further British policy; or whether he would have followed his own instincts, as Alcock had at Shimonoseki.

Given what we know of Parkes' character, it seems very likely that he would have taken matters into his own hands. It has been convincingly argued by J. Y. Wong that Parkes, then an acting Consul at Canton (Guangzhou), was the driving force behind Britain's aggressive escalation of the Arrow incident which caused the Second Opium War and made his reputation. ${ }^{69}$ Parkes urged his superiors to take a hard line, then he helped plan and took part in the resulting military actions - before London was even aware of what had occurred. ${ }^{70}$ The resulting furore in Britain sparked a snap election and bitter debate, evidence of the controversy that a distant diplomat's actions could cause. ${ }^{71}$

While Parkes may have been less hot-headed in his middle age, there was clearly a risk of a repeat of his warmongering behaviour. In 1864, the delay in communications had led Sir Rutherford Alcock to uphold British interests through force, to the initial horror of his superiors. In 1876, the only thing stopping Sir Harry Parkes from doing the same was the telegraph, which allowed the Foreign Office warning enough to countermand Parkes' plan.

Gordon Daniels believed that the telegraph, which was increasingly becoming the centrepiece of modern diplomacy, dashed Parkes' independence and left him yesterday's man. ${ }^{72}$ This is an exaggeration. As a conservative diplomat, Parkes quite likely did somewhat resent the cables linking him with home. But with the exception of his vetoed Korean venture, Parkes' loss of independence was more symbolic than real. In Parkes' time, Japan was still peripheral to British foreign policy, and telegrams sent at that distance were expensive and unreliable. The telegraph may have hindered Parkes' making a grand military gesture, but it did little to check him otherwise. He remained in his position until 1879, when he left Japan in declining health. He would die in Beijing six years later.

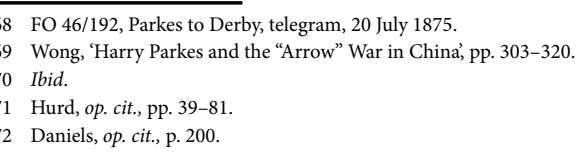




\section{Sir Ernest Satow: 1895-1900}

Sir Ernest Mason Satow (1843-1929), Britain's man in Tokyo from 1895 to 1900, was the most qualified British Minister to be stationed in Japan in the nineteenth century. Satow had served as an interpreter in the Japan legation under both Alcock and Parkes, and his tacit support for the Chōshū and Satsuma men during that period had paid dividends, as many of the friends he had made during the tumultuous Meiji Restoration were now the political elite of Japan. He spoke fluent Japanese, had a Japanese family and came to his post with a deeper understanding of the country than any predecessor. Upon Satow's arrival, Count Ōkuma Shigenobu, one of the most influential of Meiji statesmen, welcomed him as a 'man of weight', contrasting Satow with the efficient but undistinguished men who had held the post of Minister since Sir Harry Parkes. ${ }^{73}$

Satow returned to a country more confident than it had been in the Parkes era. The recent Japanese victory in the Sino-Japanese War (1894-1895) had validated the Meiji reforms of the previous quarter-century. During this conflict, the Japanese had displayed their understanding of the value of communications technology by laying their own telegraph lines across southern Korea. ${ }^{74}$ Meanwhile, British military dominance was slipping and Russian expansionism threatened British and Japanese interests equally. It would seem that the timing was fortuitous for active diplomacy: an increasing number of Japanese policymakers thought that it would make sense for Britain and Japan to conclude a military alliance and Satow was now easily contactable by his government via the telegraph. ${ }^{75}$ However, Whitehall largely left the Minister to his own devices and the Anglo-Japanese relationship stagnated from 1895 to 1900.

This is not to imply that the telegraph was being ignored by the Foreign Office. Even among the most conservative members of the Foreign Service, the telegraph had become an indispensable tool by the 1890s. In 1889 Lord Salisbury (1830-1903), a giant of British conservatism and then holding both the office of Prime Minister and Foreign Secretary, had declared of the Foreign Office that 'we positively exist by virtue of the telegraph. ${ }^{76} \mathrm{After}$ a period in opposition, Salisbury returned to power in 1895 and took up his twin positions once more, dominating British foreign policy until the close of the century.

73 Satow, The Diaries and Letters, p. 214. Satow's immediate predecessors as Minister Plenipotentiary to Japan were Sir Francis Plunkett (1884-1887), Hugh Fraser (1889-1894) and Power Henry le Poer Trench (1894-1895).

74 Daqing Yang, 'Colonial Korea in Japan's Imperial Telecommunications Network', p. 164.

75 Satow noted several conversations with Anglophile Japanese on this subject: PRO 30/33 14/9, Satow to Salisbury, 28 May 1896; PRO 30/33 14/9, Satow to Salisbury, 2 December 1896; PRO 30/33 14/9, Satow to Salisbury, 31 December 1896; PRO 30/33 14/10, Satow to Salisbury, 24 February 1898; PRO 30/33 14/10, Satow to Salisbury, 19 May 1898; PRO 30/33 14/11, Satow to Salisbury, 5 October 1899; all in Satow, The Semi-Official Letters, pp. 37, 61, 64, 98, 118, 176. 76 Salisbury, 'Speech to the Institution of Electrical Engineers', p. 13. 
Parkes had seen the beginnings of the telecommunications revolution in diplomacy; by 1895 Satow was in the middle of it. Satow was himself quick to draw the comparison in a speech he made to the foreign community at Yokohama on the day of his arrival, saying that he hoped to follow Parkes' example 'though the field of diplomatist has greatly diminished since Sir Harry's days."77 This was recognition of how much the telegraph had changed diplomacy. It was a familiar lament, one that could be heard by old-fashioned diplomats throughout the world in this period. But while the telegraph era may have spelled the end of the great diplomatic policymakers, it did not necessarily neuter consular and diplomatic staff completely.

Nonetheless, the telegraph was now the cornerstone of Satow's communications. In his Guide to Diplomatic Practice, Satow wrote that it was a diplomat's duty to utilise the telegraph:

In former times a wide discretion in the interpretation of his instructions was permitted to an envoy, in case it became necessary to take a sudden decision, but in these days, when telegraphic communication is universal, if he is of opinion that his instructions are not perfectly adapted to secure the object in view, he can easily ask for the modification he judges to be desirable. In doing this he will be well-advised to explain his reasons at full length. It is better to spend money on telegrams than to risk the failure of a negotiation. ${ }^{78}$

Of course, Satow's book, written twenty years after his service in Japan, did not necessarily reflect his methods in the 1890s. Still, Satow's official and semi-official correspondence from that period does bear out a picture of a man who made the telegraph part of his working life. The internal communications of the legation were full of telegrams, or references to them; and Satow commissioned a cottage retreat at Lake Chuzenji and induced the [Japanese] Gov. to put up a teleg. line, so that we are in touch with the outer world? ${ }^{79}$

The majority of these diplomatic telegrams were short messages being sent between the consulates within Japan. Sending an international telegram to London remained expensive, prohibitively so for some. ${ }^{80}$ However, as tends to occur when new technologies become mainstream, the price had dropped since the 1870s; by 1897 it cost 7.70 (comparatively inflated) francs per word, compared with 11 francs in $1875 .{ }^{81}$

\footnotetext{
Satow, quoted in The Japan Weekly Mail, 3 August 1985, from Satow, The Diaries and Letters, p. 201.

78 Satow, A Guide to Diplomatic Practice, p. 155

79 PRO 30/33 14/9, Satow to Salisbury, 9 July 1896, in Satow, The Semi-Official Letters, pp. 41-42.

80 One message in the Satow files begins 'Dear Mr. Lowther, the expense of telegraphing practically prevents me from communicating with the Foreign

Office': PRO 30/33 5/5, G.E.H. Barrett-Hamilton to Lowther, 24 September 1897, in Satow, The Correspondence, p. 190.

81 The price continued to drop until it reached 4.88 francs per word by 1913. Ahvenainen, op. cit., p. 205.
} 
Given this, it would seem logical that Satow would have a more harmonious and tightly controlled relationship with the Foreign Office than had his predecessors. Yet while it is true that Satow's daily affairs were dominated by the telegraph in a way unimaginable a few decades before, this had less effect on his position than might have been expected. Although the Foreign Office was capable of contacting him at any time, Satow in fact received little more guidance from Whitehall than had Alcock before him.

Soon after his arrival Satow wrote to Salisbury, 'Perhaps Y.L. [Your Lordship] may think it worthwhile to give me some directions as to the line I shld. take. ${ }^{82}$ Salisbury adhered to a policy that has often, if simplistically, been termed 'Splendid Isolation': Britain aloof from the alliances among the Great Powers, advancing her own interests peacefully while relying on her navy to protect her from aggression. ${ }^{83}$ As such, in response to his Minister's request for instructions, Salisbury encouraged Satow to 'give great attention to the commercial part of your duties', and dismissed Japan's worth as an ally, suggesting that 'in the end they will be convinced that it is in their interest to join with Russia and perhaps with France in cutting up China. ${ }^{84}$ Salisbury had thrown cold water on the idea of an Anglo-Japanese alliance for the moment, and Satow did not often raise the subject in his official despatches. Yet in his semi-official letters, of which he sent seventy-eight to Salisbury during his tenure as Minister, Satow was more garrulous and hinted at his own opinion. ${ }^{85}$ Alongside reporting conversations with Anglophilic Japanese, Satow warned:

If H.M.G were willing, Japan wld. throw herself into our arms. Most of the press advocates a close understanding c. Engld. If we do not take their side, they will be driven to make terms c. Russia. ${ }^{86}$

Salisbury remained silent on the issue, and Satow did not write as strongly on the topic again. Despite this, Satow's despatches home continued to concentrate on political issues and were disparaging about further commercial opportunity for Britain. ${ }^{87}$ This could be seen as contravening Salisbury's instructions, but Satow received little censure for this. Indeed, apart from occasional telegrams, and a message promoting him to the Chinese legation in 1900, Satow received few instructions of any kind from the Prime Minister. ${ }^{88}$ Salisbury's Private Secretary even wrote a sympathetic

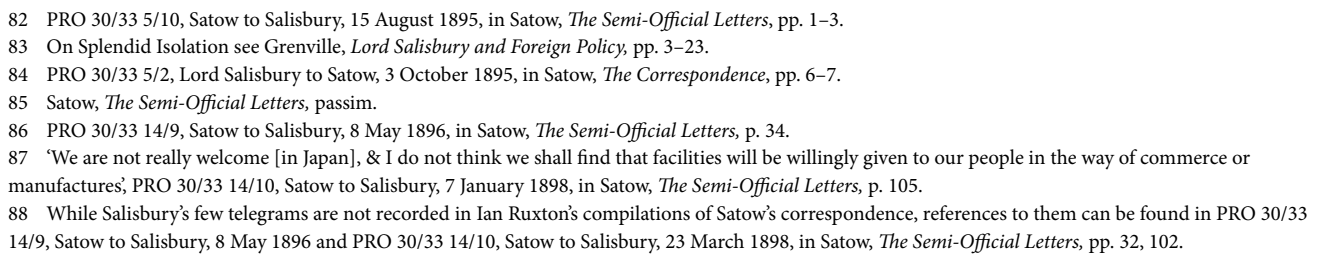


despatch to Satow assuring him that 'your letters are most interesting and you must not suppose they are not appreciated because you do not get answers from Lord Salisbury', and explaining that the Government was choosing to 'lie low as regards the Far Eastern Question'. ${ }^{89}$

Avoiding difficult decisions in Asia did not mean that the Foreign Office was as ignorant of Japan as it had been in the 1860s. A new generation of bureaucrats had come to power, to whom Japan was much more a known quantity than she had been thirty years before. After decades in which Japanese affairs were sidelined at the Foreign Office, a 'Far Eastern' department was finally formed in 1899, belatedly recognising Asia's importance in international diplomacy. ${ }^{90}$ Nonetheless, at a time when Britain faced a crumbling Turkish Empire, possible war with France over Africa and the beginnings of the Boer War, Japanese affairs were rather sidelined in Whitehall. ${ }^{11}$

Potentially, the telegraph could have revolutionised Anglo-Japanese diplomacy at the close of the nineteenth century, when Japan's growing rivalry with Russia gave the Foreign Office a golden opportunity to negotiate closer ties with Japan through the offices of Satow. In practice, while telegrams may have seemed to affect nearly every aspect of Satow's role, the core of his responsibilities was untouched.

\section{The Anglo-Japanese Alliance: 1900-1902}

The indifference from Whitehall during Satow's tenure quickly changed after his departure. In 1902 the Anglo-Japanese Alliance was signed, capping nearly half a century of diplomacy between Britain and Japan with an agreement of lasting significance. The Alliance signalled Britain's abandonment of strategic isolationism, and also symbolised that Japan had been accepted as a modern nation-state and regional power by Western decision-makers. The negotiations in 1900-1902 which preceded the Alliance also displayed the paradigm shift in diplomatic relations, to a world where the telegraph was paramount and the power of envoys and ambassadors diminished.

In 1900, Sir Ernest Satow exchanged postings with the British Minister to China, Sir Claude MacDonald (1852-1915), bringing Satow to Beijing and MacDonald to Tokyo. Within months of taking up his new post, MacDonald was recalled to London, ostensibly for leave but also to sound out his opinions on an alliance with Japan.

\footnotetext{
PRO 30/33 5/2, Eric Barrington to Satow, 29 September 1896, in Satow, The Correspondence, pp. 11-12.

90 Steeds and Nish, China, Japan and Nineteenth Century Britain, pp. 12-13.

91 For more detail on these events see Grenville, Lord Salisbury and Foreign Policy.
} 
MacDonald's return marked London as the focus for British discussion of a possible alliance, and showed the extent to which policy regarding Japan had been commandeered by the Cabinet. ${ }^{92}$ In the 1860 s British decisions on Japanese policy were for practical purposes being jointly taken by the Foreign Secretary and the Minister Plenipotentiary, but as Japan's importance on the world stage had increased so the decision-making process on Japanese matters had shifted away from the Minister on the spot and towards the Cabinet as a whole. MacDonald's opinion carried great weight and was personally sought by Salisbury, but his role in shaping policy seems to have been minimal. It was primarily Lord Lansdowne (Foreign Secretary 19001905) and Francis Bertie (head of the Asiatic Department at the Foreign Office) who constructed the Anglo-Japanese Alliance from the British side. After MacDonald returned to Tokyo, his role seems to have primarily been the delivery of drafts and counter-drafts from London to the Japanese government, although he continued to cable useful reports. ${ }^{93}$

To the last, Lord Salisbury remained uncertain of the wisdom of the Alliance. In the last major foreign policy memorandum of his career, the Prime Minister warned that it could see Britain dragged into an unwanted conflict over Korea. In his rebuttal to the argument that the alliance would allow for a quick reaction to a crisis, the old statesman finished with a familiar conviction on the flexibility offered by new technology:

The necessity for a decision so sudden that the telegraph will not be able to cope with the emergency is not a very probable contingency, and certainly does not furnish a justification for surrendering without reserve into the hands of another Power the right of deciding whether we shall or shall not stake the resources of the Empire on the issue of a mighty conflict. ${ }^{94}$

Salisbury saw that the very nature of state alliances had been undermined by the technology that had revolutionised nineteenth-century diplomacy. However, his misgivings were ignored. The Anglo-Japanese Alliance was signed on 30 January 1902, the first of several dramatic changes in the relationship between Britain and Japan in the new century. ${ }^{95}$ The nineteenth-century world of Alcock, Parkes and Satow had passed; and while the subsequent diplomats held the rank of Ambassador, their autonomy and consequence was never to reach the heights achieved by those three men. ${ }^{96}$ 


\section{Conclusion}

Historians such as Jones, Headrick and Nickles are right that the telegraph fundamentally altered the conduct of diplomacy. In the case of Japan and the United Kingdom, by 1900 the telegraph allowed the Foreign and Prime Ministers to play a much more handson role in negotiations than they could have a few decades before. While an AngloJapanese alliance would have been theoretically possible (if absurd) in the years before 1870 , it would have been exceedingly impractical to negotiate and implement without telegraphic communications.

Despite the degree to which the telegraph facilitated the alliance negotiations, this finding in itself does not completely bear out technologically determinist theories of the transformative power of technology. While the telegraph did end the unchecked gunboat diplomacy that had been a staple of British behaviour on the fringes of Empire in earlier decades, in most other fields the coming of the telegraph did not at first much modify a Minister's decision-making power. The Foreign Office was too busy, and lacked the necessary experience, to make regular judgements on the everyday problems that diplomats dealt with - especially since, for most of the nineteenth century, Japan was to them an exotic backwater. Its geographical position at the opposite side of the globe also made it particularly expensive to communicate with via cables. For these reasons, there was not enough incentive for the Foreign Office to micromanage the affairs of the man on the spot. The rise of Japan to foremost power in Asia, and the subsequent signing of the Anglo-Japanese Alliance in 1902, greatly increased the importance of Japan to the British, and marked the end of the independent envoy, ironically just before the position was officially upgraded to Ambassador.

There remains room for further research. Space limitations precluded an analysis here of the effect the telegraph had upon communication between Ministers stationed in neighbouring countries. Given the speed with which letters could be posted between Beijing and Japan, the telegraph would not have revolutionised the two consulates' relationship, but it might have allowed for closer cooperation on matters such as Korean policy. The time lag then, between potential centralised control, from 1870, and actual control, around 1901, shows that technological progress does not, in itself, drive history; it requires the will to utilise that technology by the people in power: a lesson that can be applied to a much wider canvas than Anglo-Japanese diplomacy. 


\section{References}

\section{PRIMARY SOURCES}

\section{Archive Sources}

British Foreign Office: Japan Correspondence, 1856-1905.

F.O. 46: 101, 102, 103, 125, 180, 189, 192, 200, 204.

\section{Printed Sources}

Bourne, K., and Watt, D. C., (general eds.), British Documents on Foreign Affairs: Reports and Papers from the Foreign Office Confidential Print. Part 1: From the Mid-Nineteenth Century to the First World War. Series E: Asia, 1860-1914. Vol. 1, Japan and North-East Asia, 1860-1878, Ian Nish (ed.) (Frederick, Maryland: University Publications of America, 1989).

British Parliamentary Papers, Japan 1: Reports, Returns and Correspondence Respecting Japan, 1856-64 (London: H.M.S.O., 1856-1864; reprint Shannon, Ireland: Irish University Press, 1971).

British Parliamentary Papers, Japan 2: Reports and Correspondence Respecting Japan, 1864-70 (London: Harrison and Sons, 1864-70; reprint Shannon, Ireland: Irish University Press, 1971).

British Parliamentary Papers, Japan 3: Reports, Correspondence, Returns and Dispatches Respecting Japan, 1871-99 (London: Harrison and Sons, 1871-1899; reprint Shannon, Ireland: Irish University Press, 1971).

Kajima, Morinosuke, The Diplomacy of Japan: Volume 2: Anglo-Japanese Alliance and Russo-Japanese War (Tokyo: Kajima Institute of International Peace, 1978).

Salisbury, Lord R. C., 'Speech to the Institution of Electrical Engineers', The Electrician, No. 599, Vol. 24 (8 November 1889), pp. 12-15.

Satow, E., in Ruxton, I. (ed.), The Correspondence of Sir Ernest Satow while he was British Minister in Japan, 1895-1900 (Kyūshū, Japan: Ian Ruxton, 2005).

Satow, E., in Ruxton, I. (ed.), The Diaries and Letters of Sir Ernest Mason Satow, 1843-1929, A Scholar-Diplomat in East Asia (Lewiston, New York: E. Mellen Press, 1998).

Satow, E., A Diplomat in Japan (London: Seeley \& Co., 1924; reprint, Tokyo, New York: Oxford University Press, 1968).

Satow, E., in Ruxton, I. (ed.), The Semi-Official Letters of British Envoy Sir Ernest Satow from Japan and China, 1895-1906 (Morrisville, North Carolina: Lulu Press, 2007).

\section{SECONDARY SOURCES}

Ahvenainen, J., The Far Eastern Telegraphs: The History of Telegraphic Communications Between the Far East, Europe, and America before the First World War (Helsinki: Suomalainen Tiedeakatemia, 1981).

Baark, E., Lightning Wires: The Telegraph and China's Technological Modernization, 1860-1890 (Westport, Connecticut: Greenwood Press, 1997).

Beasley, W. G., The Meiji Restoration (Stanford, California: Stanford University Press, 1972).

Checkland, O., Britain's Encounter with Meiji Japan, 1868-1912 (Basingstoke: Macmillan, 1989).

Cortazzi, H. (ed.), British Envoys in Japan, 1859-1972 (Folkestone, Kent: Global Oriental, 2004). 
New Voices Volume 3

Daniels, G., Sir Harry Parkes: British Representative in Japan, 1865-1883 (Richmond, Surrey: Japan Library, 1996).

Fox, G., Britain and Japan, 1858 - 1883 (Oxford: Clarendon Press, 1969).

Galbraith, J. S., 'The "Turbulent Frontier" as a Factor in British Expansion', Comparative Studies in Society and History, Vol. 2, No. 2, pp. 150-168 (Cambridge University Press, January 1960). Retrieved 18 August 2008, from http:// www.jstor.org/stable/177813.

Grenville, J. A. S., Lord Salisbury and Foreign Policy: The Close of the Nineteenth Century (London: University of London, Athlone Press, 1964).

Hane, M., Modern Japan: A Historical Survey (Boulder: Westview Press, 1986).

Headrick, D., The Invisible Weapon: Telecommunications and International Politics (New York: Oxford University Press, 1991).

Headrick, D., When Information Came of Age: Technologies of Knowledge in the Age of Reason and Revolution, 17001850 (Oxford: Oxford University Press, 2000).

Hurd, D., The Arrow War: An Anglo-Chinese Confusion (London: Collins, 1967).

Itoh, E., 'The Danish Monopoly on Telegraph in Japan', Keio Communication Review, No. 29 (2007), pp. 85-105.

Jansen, M., The Making of Modern Japan (Cambridge, Massachusetts: Harvard University Press, 2000).

Jones, R., The British Diplomatic Service: 1815-1914 (Gerrards Cross: Smythe, 1983).

Kajima, M., A Brief Diplomatic History of Modern Japan (Rutland, Vermont: Tuttle, 1965).

Nickles, D. P., Under the Wire: How the Telegraph Changed Diplomacy (Cambridge, Massachusetts: Harvard University Press, 2003).

Nish, I., The Anglo-Japanese Alliance: The Diplomacy of Two Island Empires, 1894-1907 (London: Athlone Press, 1966).

Nish, I. and Steeds, D., China, Japan and Nineteenth Century Britain (Dublin: Irish University Press, 1977).

Preston, A. and Major, J., Send a Gunboat! A Study of the Gunboat and its Role in British Policy, 1854-1904 (London: Longmans, 1967).

Satow, E., A Guide to Diplomatic Practice, 2 volumes, third edition (London: Longmans, 1922; reprinted Bristol: Ganesha Publishing; Tokyo: Edition Synapse, 1998).

Standage, T., The Victorian Internet: The Remarkable Story of the Telegraph and the Nineteenth Century's On-Line Pioneers (London: Weidenfeld \& Nicolson, 1998).

Williams, R., 'The Idea of “Technology” and Postmodern Pessimism', in Smith, M. R., and Marx, L., (general eds.), Does Technology Drive History: The Dilemma of Technological Determinism (Cambridge, Massachusetts: MIT Press, 1994), pp. 237-258.

Wong, J. Y., 'Harry Parkes and the "Arrow” War in China', in Modern Asian Studies, Vol. 9, No. 3 (1975), pp. $303-320$. Retrieved 10 May 2008, from http://www.jstor.org/stable/311739.

Yang, D., 'Colonial Korea in Japan's Imperial Communications Network', in Shin, G-W., and Robinson, M (eds.), Colonial Modernity in Korea (Cambridge, Massachusetts and London: Harvard University Asia Centre, 1999). 


\title{
Things That are Near Though Distant: Extramarital Affairs in Heian-Period Japan
}

Matthew Grubits

University of Tasmania

\begin{abstract}
According to historian William McCullough, a society cannot be understood without an appreciation of its marriage institutions, for marriage institutions are a dominant strand in the fabric of any society. In the Heian period, however, there was an even more dominant strand in the fabric of society than marriage that impinged on the relationships between aristocratic men and women. As historian Ivan Morris points out, the most prevalent relationships between men and women were extramarital affairs. If an appreciation of marriage institutions is necessary for us to understand Heian society, then an appreciation of affairs is likewise necessary.
\end{abstract}

Few historians have addressed the subject of affairs, though they are central to the most notable texts from the period. This article addresses this gap in scholarship by exploring why affairs were so prevalent during the Heian period. This exploration involves looking at the marriage institution, perceptions of sexuality, belief systems and, importantly, aestheticism. Heian society was intensely aesthetic - a great emphasis was placed on pathos, beauty and aesthetic acts such as composing poetry. This paper argues that affairs were themselves aesthetic acts; that is, they were occasions of aesthetic expression. Because aristocrats had a preoccupation with aestheticism, they embraced affairs.

\section{Keywords}

Aesthetics, aristocrats, gender relations, Genji, Heian

\section{Introduction}

One of the three things the Heian-period lady-in-waiting Sei Shōnagon includes in her list of 'Things That are Near Though Distant' is 'Relations between a man and a woman.' William McCullough, a scholar of Heian-period Japan, argues an understanding of

1 Shōnagon, The Pillow Book, p. 181. 
relations between men and women is vital for the historian to appreciate any given society. He places particular emphasis on marriage institutions, for 'Marriage institutions constitute one of the dominant strands in the fabric of every human society, shaping the family, determining relationships among individuals...'2 There was, however, an even more dominant strand in the fabric of Heian society than marriage institutions. Ivan Morris writes in his well-known book The World of the Shining Prince, the 'numerically most frequent type of relations between men and women in Heian-kyō were those of a casual and promiscuous nature.' If, as McCullough suggests, understanding marriage institutions is necessary to better understand Heian society, then so too is understanding casual and promiscuous relationships.

Few scholars of the Heian period have specifically studied extramarital relationships. Morris is perhaps the most explicit on the matter. It may seem his engagement with the subject was inevitable, given the strong links between Shining Prince and The Tale of Genji (Genji monogatari), to which extramarital relationships are central. Other scholars who have also engaged with Genji, however, have avoided the subject. While this could suggest historians are hesitant to place too much emphasis on extramarital relationships from prudery or a fear the Heian period will appear debauched, it is more likely historians have neglected the subject because the ubiquity of extramarital relationships has lessened their significance. Recently, historians have neared the topic by exploring gender roles, sexuality and morality. Noteworthy among these are Hitomi Tonomura and Janet Goodwin. ${ }^{4}$ It may be that discussions such as theirs were necessary before discussions on extramarital relationships could proceed.

This article addresses this gap in scholarship by exploring why extramarital relationships were so prevalent in the Heian period. It looks at marriage institutions, perceptions of sexuality, religion and, importantly, aestheticism. As shall be seen, all of these aspects of Heian life encouraged, facilitated and legitimised extramarital relationships. Hereafter, these relationships will be simply referred to as affairs, meaning extramarital, heterosexual, sexual relationships, not limited to adultery, but also including fornication and rape as they are commonly understood today. Like most discussions of the Heian period, this article only relates to aristocratic Heian society; to those people variously called the cultured people, the courtly people, the people of rank, and the good people. 
Much can be learnt about the aristocrats and their affairs from such wellknown works of Heian literature as the aforementioned Tale of Genji by Murasaki Shikibu, The Pillow Book (Makura no sōshi) by Sei Shōnagon, and The Gossamer Years (Kagerō nikki) by the Mother of Michitsuna. At the time these works were composed, affairs were a common part of everyday life. These works reveal an aristocratic man was generally free to enter an affair with any woman, heedless of her identity, age and marital status. While not impossible, it was less likely for a man to have a relationship with a woman above his own rank. Affairs involved people of all ages. When she is between thirty and forty years old, the Mother of Michitsuna discovers her father is still philandering when he announces the birth of another child. ${ }^{5}$ When only nineteen years old, Genji spends the night with the fifty-seven or fifty-eight year old Dame of Staff. ${ }^{6}$ Genji has numerous affairs; in addition to having sexual relations with his wife Aoi, Genji has sexual relations with his father's concubine Fujitsubo, a married woman Utsusemi, and, among others, a woman whose identity he does not even know, Oborozukiyo. A man could have as many lovers as he could manage, be they women he visited at their residence, or installed in his own residence. Affairs could last for a single night or many years.

\section{Marriage}

The nature of Heian marriage institutions has been extensively discussed, most notably by McCullough. Marriages were polygynous and matrilocal, and were arranged for economic, political and practical reasons. Both McCullough and Tonomura tell us marriage was merely a social process that was neither sanctioned nor confirmed by law, Buddhism or Shinto. ${ }^{7}$ Divorce was similarly a social, non legal process; it was effected by no formal procedure, but was simply a matter of ending relations. ${ }^{8}$

An aristocrat was usually first married at puberty to someone of a similar age; of the pair, the girl was usually older than the boy. ${ }^{9}$ If a man took subsequent wives, his first wife would remain the principal wife and have precedence over the subsequent wives. ${ }^{10}$ While a man's first wife was usually chosen for him by his parents, he was generally free to choose his subsequent wives. A man may have taken a second wife out of love or if his first wife failed to have children. ${ }^{11}$

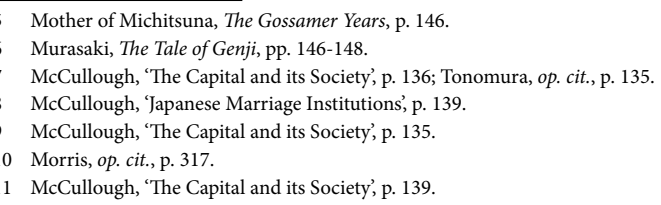


Upon marriage, a boy would usually move in with his wife and her parents. By moving into their house, a boy became reliant on his parents-in-law for economic support. Indeed, only upon their death might he be required to provide for himself and his wife. ${ }^{12} \mathrm{~A}$ boy relied on his father-in-law, rather than his own father, for political success. ${ }^{13} \mathrm{~A}$ man who had many daughters, then, was in a better position than a man who had many sons, for while sons would eventually leave him and rely on other men for support, he could carefully select husbands for his daughters whom he could influence and use to gain a political advantage for himself. While it was impossible for an aristocrat's son to ever become an emperor, there was always the possibility that his daughter could become an imperial consort and even the mother of an emperor. ${ }^{14}$

Matrilocal habitation may have been common because many marriages occurred between children who were incapable of running their own household. ${ }^{15}$ Older couples may have practised neolocal marriage, depending on their circumstances and the availability of space in the bride's family home. ${ }^{16}$ Neolocal arrangements in which the man provided the house were often associated with romantic love, for only love could attract a man to a woman who could not provide him with a house or any political or economic advantage. ${ }^{17}$ In some circumstances a couple had neither a matrilocal nor neolocal marriage; instead, they lived separately with the husband visiting the wife.

Even when husband and wife did live in the same house, they might not have cohabited in the same pavilion. This meant that husbands and wives, whether they lived together or apart, were not necessarily in close contact with one another. Although a husband could meet with his wife face-to-face without any obstructing screens, faceto-face meetings were unnecessary for communication. If not more convenient, it was certainly more aesthetic for a husband and wife to communicate via notes and poems. But even when in communication, there was every opportunity for both parties to live in relative independence. A husband could easily avoid the eyes of his wife while visiting and receiving whomever he pleased. While, then, it may not have been the case in the majority of households, there was the very real possibility that a husband and wife could be little more than acquaintances. Because of this physical distance and the ease with which couples could avoid one another, I would argue Heian marriage institutions did not foster loving relationships and thereby encouraged affairs.

\footnotetext{
Hurst, 'Kugyō and Zuryō', p. 72.

3 McCullough, 'Japanese Marriage Institutions', pp. 126-127.

4 Morris, op. cit., p. 207. Fujiwara no Michinaga, the son of Fujiwara no Kaneie by a wife other than the Mother of Michitsuna, certainly proved the value

of daughters. Michinaga was able to gain authority through marrying his daughters to important men; see Sanae and Watanabe, 'From Female Sovereign', pp.

30-32, and Hurst, op. cit., pp. 70-71.

15 McCullough, 'Japanese Marriage Institutions', p. 117.

16 Ibid.

17 Ibid., pp. 114-115; McCullough, 'The Capital and its Society', p. 138.
} 
Something of this can be seen in the marriage of Genji and Aoi. Genji is twelve years old and Aoi sixteen at the time of their marriage. Aoi, though she, like everyone, finds Genji extremely attractive, is embarrassed to be linked to someone so young. Genji, meanwhile, dreams only of Fujitsubo, his father's concubine, who reminds him of his dead mother. Because he is required to serve there, Genji more frequently resides at the palace than he does with his new wife. ${ }^{18}$ This physical distance, combined with Genji's preoccupation with Fujitsubo, creates an instant divide between the newlyweds that never truly closes. Although they have sexual relations, Genji is more interested in other women, and this annoys Aoi. Following her death at the age of twenty-six, Genji 'wondered in vain regret why she had taken such offence at each of his casual diversions, undertaken while he complacently assumed that she would eventually change her mind about him, and why she had persisted to the end in disliking him so.' ${ }^{39}$

As Haruo Shirane suggests, only outside marriage does Genji find true love. ${ }^{20}$ While his marriage to Aoi is unfulfilling, and even confusing, Genji finds satisfaction in extramarital affairs. Affairs, rather than marriage, cater to his aesthetic interests in romance, beauty and poetry. ${ }^{21}$ Shirane also points out that, unlike in Genji's extramarital relationships, not a single poem passes between Genji and Aoi, illustrating the absence of love and aestheticism in marriage. ${ }^{22}$ Marriage, this suggests, contributed to the prevalence of affairs by failing to be aesthetic and romantic outlets for aristocrats.

\section{Shōnagon includes in her list of 'Depressing Things'}

With much bustle and excitement a young man has moved into the house of a certain family as the daughter's husband. One day he fails to come home, and it turns out that some high-ranking Court lady has taken him as her lover. How depressing! "Will he eventually tire of the woman and come back to us?" his wife's family wonder ruefully. ${ }^{23}$

Like Genji, this young man feels no particular loyalty to his wife and, therefore, has no apparent qualms about becoming the lover of the high-ranking court lady. As the court was the centre of cultural expression, a court lady would hold far more appeal to the aesthete than would a woman who was somewhat removed from the court. A court lady could also potentially offer more political advantage. It is noteworthy that Shōnagon does not write of the young man's actions 'how inappropriate' or 'how

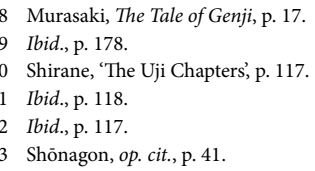


infuriating' but rather 'how depressing. His actions can hardly be condemned, for he has the freedom to come and go from his matrimonial home as he pleases and become romantically involved with women other than his wife. This further illustrates that marriage promoted affairs by not fostering love and not precluding either partner from seeking love elsewhere.

Marriage institutions may also have encouraged affairs in other ways. The newlywed boy and girl may have felt uncomfortable initiating sexual relations, either upon marriage or upon sexual maturation. It may have been more comfortable for a young man to enter a sexual relationship with someone other than the bride with whom he had grown up, and beyond the prying eyes of his parents-in-law. It is also possible love did not develop between many newlyweds, causing one party, or both, to look outside marriage for a fulfilling relationship.

\section{Sexuality}

Perceptions of sexuality allowed men and women to engage in extramarital affairs. Tonomura tells us sexual gratification, for both men and women in Heian Japan, was understood to be dependent on the presence of a male body; that is, a woman could only obtain sexual gratification through intercourse with a male, whereas a male, possessing a male body, could legitimately obtain gratification in a number of ways, from pederasty to masturbation. ${ }^{24}$ Men, due to the very nature of their physical composition, were afforded a greater range of sexual experiences than women, while women were made reliant upon men.

Male desire was considered innate and uncontrollable. ${ }^{25}$ This, Goodwin suggests, meant men could not be blamed for sexual misdemeanours, for they were driven by a natural force over which they had no power. ${ }^{26}$ Because they were perceived to be incapable of resisting desire, men could not be criticised for sexual acts we would not hesitate to call deviant today, such as rape; the uncontrollable nature of desire gave men permission to satisfy their lusts even in an unwilling female. ${ }^{27}$ Any violation that occurred was the result of passion, and if anyone was to blame, it was the female for letting her guard down. ${ }^{28}$ Women were further responsible for unsolicited propositions because, while they may not have actively encouraged any propositions,

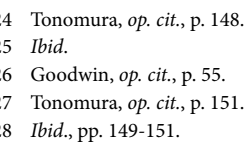


women were, by their very nature, enticing objects to men. ${ }^{29}$ Women were, by nature, irresistible, while men were, by nature, unable to resist.

While it was the responsibility of women to resist violation, a woman was also expected to be a passive recipient of sexual advances and any ensuing sexual activity. Assertive sexual behaviour on the part of a woman was considered unnatural and dangerous to both men and to herself. ${ }^{30}$ A woman who was not submissive could be accused of being a fox, or a teng $u$ in female form, for, through not submitting, she did not conform to what was perceived to be normal. ${ }^{31}$

To further complicate the matter, a sexually inactive woman could also be considered to be abnormal. Morris writes, 'virgins were unusual in well-born families ... it was firmly believed that any girl who remained virgin for long had been possessed by an evil spirit. ${ }^{32}$ While people believed in possession, transforming foxes and tengu, it is unclear how often people were accused of being unhuman due to sexual apathy. If frequently, then people everywhere would surely have made certain they were seen to have a lover from fear of condemnation. The primary literature, however, does not suggest this was so. Indeed, in The Tale of Genji, rather than condemning the sisters at Uji for their chastity, friends Kaoru and Niou take a great interest in them. ${ }^{33}$ While, then, women may not have engaged in affairs merely from fear of being considered unhuman, superstition did encourage the view that the average woman participated in affairs.

The Heian woman, then, was not to be actively seductive, yet she was expected to be sexually active; she was supposed to prevent unwanted sexual encounters, yet she was also supposed to be submissive to men. While this, in theory, seems contradictory, Murasaki depicts women as having a less complex, less prescriptive approach to sexuality. Men, it would seem, did not begrudge women who were either reticent or outgoing:

Her Majesty frowns on the slightest hint of seductive behaviour as being the height of frivolity, so anyone who wants to be thought well of takes care never to seem too forward. Of course that is not to say we do not have women among us of quite a different persuasion, women who care nothing for being thought flirtatious and light-hearted and getting a bad name for themselves. The men strike up relationships with this kind of woman because they are such easy game. ${ }^{34}$ 


\section{Religion}

Buddhism and Shinto both contributed to Heian views of sexuality and morality, and both, in different ways, supported extramarital affairs. The Heian aristocrat, however, seems to have had little real interest in religious doctrine. Edward Seidensticker writes of the aristocrat:

Good taste was his religion, and he was not given to speculative thought. This is not to say that he had no use for revealed religion; rather that he was not much worried about putting the universe in order, that religious notions and ceremonies but served to intensify the sweet sad beauty of the moment... ${ }^{35}$

The aristocrat was no religious zealot or fundamentalist; rather, in the Japanese tradition, aristocrats appropriated those parts of Buddhism and Shinto that supported their aesthetic lifestyle and world view. The Heian aristocrat was more interested in sentimentality and taste than spiritual speculation. ${ }^{36}$

In opposition to this view, one might argue that the frequently aired wish of the Heian aristocrat to retreat into monasticism demonstrates real spiritual fervour. It was, however, conventional for aristocrats to express a desire to retreat into monasticism; they were surely all too aware of the realities of monasticism and, therefore, thankful for any obstacles that prevented them retiring from the cultured life of the capital. ${ }^{37}$ The Mother of Michitsuna expresses as much when she writes, 'The priest ... was at the bank to say good-by, a sad expression on his face. It occurred to me that it would hardly be pleasant to stay on year after year in this temple, familiar to the point of boredom. ${ }^{38}$ People spoke of renouncing the world because it was fashionable and appropriate to do so. Ultimately, if the many people who expressed a wish to retreat into monasticism were genuine, they would have rejected those transitory things that prevented a retreat and acted upon their wishes immediately.

In The Gossamer Years, there is an incident in which the children of a banished Minister of the Left are forced to become priests. ${ }^{39}$ The Minister himself becomes a priest, but his position is not recognised and he is made Governor-General of Kyushu instead, an apparently shameful position. ${ }^{40}$ This would suggest becoming a priest was both a way of escaping society and akin to punishment. By becoming a priest one was

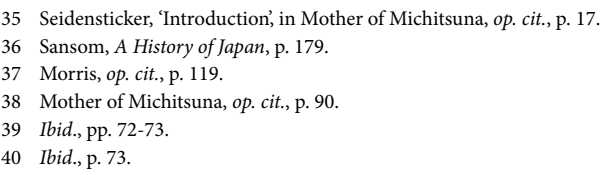


physically removed from Heian-kyō and the esteemed lifestyle it alone could offer. Anybody away from the city, be they in a distant province or in a monastery, was not interacting with elegant aesthetes and, therefore, in danger of becoming uncultured. If such was used as punishment for aristocratic transgressors, retreating into monasticism, though frequently spoken of, was surely not something most aristocrats truly wanted.

Heedless of whether or not the aristocrats were devout, Buddhism and Shinto still legitimised their affairs. Interestingly, though, the greatest difference between Buddhism and Shinto lay in their attitudes towards sexuality. ${ }^{41}$ Whereas Buddhism saw sex as a cause for continual rebirth into the terrestrial world, Shinto saw sex as something creative and productive. ${ }^{42}$ Shinto, then, by its very nature, saw affairs as positive acts. Of Shinto and Buddhism, though, Buddhism was more important to the aristocrats. ${ }^{43}$

Under Buddhism there was no concept of sin as under Christianity. Not wholly dissimilar to the Christian understanding of sin, though, was the Buddhist understanding of desires, which were illusions and obstructions to Buddhahood. ${ }^{44}$ With no concept of sin, there was no absolute right and wrong, merely behaviour that was beneficial and behaviour that was detrimental. Violation of a woman, then, was not inherently wicked, but a potential obstruction to a man obtaining Buddhahood. Violation, though, was no more a potential obstruction than any act born of desire. Matrimonial intercourse, equally a product of desire, was likewise an obstruction to Buddhahood. If even matrimonial intercourse could be disadvantageous, then rape, fornication and adultery were no less terrible deeds. All sexual activity, because it was caused by desire, was equal in its detriment and cause for suffering and rebirth.

Buddhism, though, for all its emphasis on shunning desire, could hardly condemn sexual activity outright, or else its followers would die out and with them the possibility of rebirth into a human form. Buddhism, then, conceded the inevitability of sexuality, and did not discourage sexual intercourse, only the desire for it. ${ }^{45}$ If all sexual activity was equal, and one form of sexual activity was allowed, then all forms of sexual activity were legitimised. Buddhism, then, can also be seen to support affairs, even while it viewed affairs as causes for suffering because of their links to desire. Buddhism may also have encouraged Heian-period aristocrats to view affairs in a similar way to the Kamakura-period Retired Emperor GoFukakusa: 'After thinking about the subject at great length, I have concluded that there is nothing sinful in the

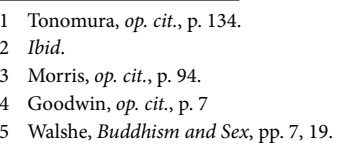


relationships between men and woman inasmuch as they are usually caused by bonds from former lives and thus defy our resistance. ${ }^{36}$

\section{Aestheticism}

In his introduction to The Gossamer Years, Seidensticker writes, 'Perhaps the most striking feature of aristocratic Heian life, however, is its emphasis on good taste. Inaction, a word which seems to describe the tone of Heian life better than "effeminacy," gave rise to a vast and minute cultivation of taste and form. ${ }^{47}$ This 'cultivation of taste and form', which Morris calls the 'cult of beauty' and which I will simply call Heian aestheticism, bordered on the obsessive. The aristocrat strived to express beauty at every available opportunity. This preoccupation with beauty greatly contributed to the self consciousness of Heian society. Aristocrats were always on their guard lest they should appear ugly, graceless, apathetic or artless. Those who did exhibit these unfortunate characteristics became the subjects of mockery and gossip, and suffered severe embarrassment and humiliation.

The most obvious forms of aesthetic expression in Heian narratives are clothing and poetry. Liza Dalby points out that both clothing and poetry were means by which the aristocrat could demonstrate his or her sensibility and sensitivity. ${ }^{48}$ The aristocrat did so through complimenting the colours of their clothing with the season, by making appropriate, imaginative and novel allusions in poetry, and by always exhibiting personal flair within the narrow parameters of propriety.

In her diary (Murasaki Shikibu nikki), Murasaki writes:

I observed the ladies as they passed ... Those to whom the colours were forbidden, especially the older ones among them, had been careful to avoid anything out of the ordinary and had dressed simply in beautiful robes of three or four layers ... Now, as they looked at each other, they suddenly realised how, although each one of them had tried to show some originality, those of a common age are bound to have common tastes. There was a strong atmosphere of rivalry. ${ }^{49}$

There was a precise art to matching one's robes in both an appropriate and attractive way. Everyone, however, was not equal in skill, as Murasaki reveals:

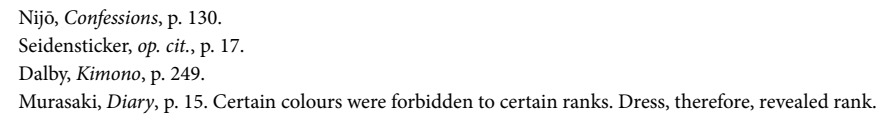


... all the women had done their utmost to dress well, but, as luck would have it, two of them showed a want of taste when it came to the colour combinations at their sleeves, and as they served the food they came into full view of the nobles and senior courtiers. Later, it seemed that Lady Saishō and the others had been mortified; but it was not such a terrible mistake - it was just that the combinations were rather uninspiring ... The slightest mistake in a formal setting should indeed be the subject of censure... ${ }^{50}$

While men took no less care than women in matters of dress, dress was particularly important to women because, generally, their clothing was all men saw of them. When in the company of men, women were usually hidden behind screens. A woman could display a part of her sleeve or the hem of her costume beneath her screens to reveal her presence and the colour combinations of her robes. When travelling, a woman could display the combinations of her robes by wearing her sleeve outside her carriage. ${ }^{51}$ The colours of a woman's outfit revealed her nature and level of taste. Because women's faces were hidden, men assessed women by their costume, and even fell in love with women by glimpsing a sleeve or hem.

Like clothing, handwriting also revealed a woman's character and, like her clothing, could inspire love. Handwriting, more than speech, revealed a woman's character and breeding. ${ }^{52}$ A woman's reply to a poem, then, was one way a gallant could confirm the nature of a woman whose sleeve he had glimpsed. Poems and letters were ubiquitous in Heian Japan; they pervaded every aspect of Heian life. Every aristocrat was a poet to some degree. Poetry competitions were held, poetry anthologies were created, everyday conversation held allusions to poetry.

At the foundation of Heian aestheticism was a melancholy outlook. In Heian narratives, men and women frequently refer to wet sleeves, indicative of tears they have shed and wiped away. Weeping was accepted and even considered admirable, because it demonstrated emotional sensitivity. The ability to be moved by appropriate things, frequently transient things such as meetings, blossoms, autumn leaves and snow, was central to courtly refinement. ${ }^{53}$ This melancholic, emotional outlook was encouraged by the nature of Buddhism, but Buddhism cannot be considered the sole progenitor of every aspect of Heian aestheticism, for there was also a brighter, more cheerful side to it. Processions, even dress, reveal a love for pomp and ostentatious display, and the Heian aristocrat was equally as capable of witty conversation as he or she was of lapsing into a depression.

\footnotetext{
50 Ibid., p. 65

51 For a discussion on this practice, see Dalby, op. cit., pp. 247-248.

52 Sansom, op. cit., p. 186.

53 Varley, Japanese Culture, pp. 60-61.
} 
George Sansom suggests aestheticism roused stronger emotions in aristocrats than did their affairs. ${ }^{54}$ I would suggest aestheticism and affairs can not be separated from one another, and that affairs were actually a form of aesthetic expression. The aristocrat's occupation with aestheticism was not distinct from an interest in affairs, but incorporated an interest in affairs. This link, I would suggest, helps us understand why the aristocrats embraced affairs; affairs, being aesthetic acts, appealed to aristocrats as much as did the writing of poetry or the connoisseurship of robes.

\section{The Aesthetic Affair}

Morris argues that the rule of taste prevented affairs from 'degenerating into something crass and sordid. ${ }^{55}$ An affair, he writes, was, 'from beginning to end conducted according to an elegant ritual, with a strong aesthetic sense of how things should be done. ${ }^{56}$ Paul Varley agrees: 'the typical love affair was conducted according to exacting dictates of taste. ${ }^{57}$ This ritualisation and association with aestheticism, I would suggest, makes affairs aesthetic acts in themselves, as much so as the writing of poetry, and, therefore, appealing to the aesthetically-minded aristocrat.

Poems and letters played a particularly important role in the conduct of an affair. The Gossamer Years provides two examples of men using correspondence to proposition a woman. Michitsuna, perhaps after admiring her sleeve hanging from her carriage, enters correspondence with the mysterious 'lady from Yamato. ${ }^{58}$ The lady refuses to be wooed. Michitsuna's uncle, the Kami, begins a much more formal correspondence with the author regarding her adopted daughter. ${ }^{59}$ The Kami, most likely with thoughts of marriage, first asks the Mother of Michitsuna if he might begin seeing her adopted daughter. This shows the ritual that preceded relationships, the use of aesthetic expression in courting, and also the limited power aestheticism afforded women. Providing a man adhered to the aesthetic convention of approaching a woman through poetry and letters, a woman had the power to either discourage or encourage the advances of her suitor. Given Heian perceptions of sexuality, however, her power could be easily overridden.

Shōnagon writes of letters playing a role in the course of an affair. On at least two occasions she mentions the next-morning letter, which it was customary for a

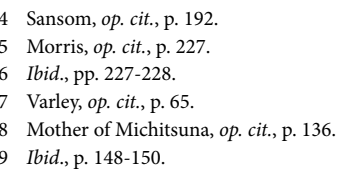


man to send his lover upon leaving her after a night of passion. In 'A Young Bachelor' Shōnagon paints a romantic picture of a young man returning home and taking great care in the composition and delivery of his next-morning letter. ${ }^{60}$ A reply returns while the young man is reciting the sixth scroll of the Lotus Sutra and, such is his affection for his lady, he immediately returns his attention to her. In 'On One Occasion a Man' Shōnagon describes a far less romantic experience in which a man, 'who invariably sent me a letter after we had spent the night together, declared that he saw no point in our relationship and that he had nothing more to say to me.' ${ }^{61}$ The relationship between the Mother of Michitsuna and Fujiwara no Kaneie is ended with an exchange of poems. ${ }^{62}$

Interestingly, poetry, like affairs themselves, could be seen as contradictory to Buddhist principles. ${ }^{63}$ Poems, because of their content, could be regarded as frivolous and untrue and, therefore, detrimental to one's spiritual wellbeing. ${ }^{64}$ Poems, however, as has been mentioned already, were not only accepted by Heian society, but were as pervasive as were affairs. I would suggest there is a similarity in the way Heian society embraced poetry and the way it embraced affairs. I would also suggest poems and affairs fed off one another. Poems initiated affairs, and affairs initiated poems; poems and affairs were inseparable. This association with poetry strengthens the view that affairs were aesthetic acts. Poems, clearly aesthetic products, imbued affairs with a positive, aesthetic nature.

It has also been mentioned already that the Heian aristocrat frequently expressed the act of weeping by reference to damp sleeves. This is an example of clothing being used, without reference to colour combinations, to express aestheticism, specifically sensitivity. Liza Dalby writes, 'Romantic relations between men and women could not help but be influenced by the voluminous envelopes of clothing worn by the beau monde. Romance was expressed through poetic convention in images of tear-damp sleeves and spread-out robes.' 65 This, I suggest, is another example of affairs being linked to a conventional form of aesthetic expression, namely dress.

Aestheticism was not only present in affairs materially, it was also present ideologically. Aestheticism determined how affairs were conducted through propriety. Shōnagon suggests on a number of occasions that there was a right and a wrong way to conduct a relationship. She writes, for example:

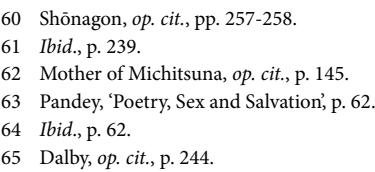


A lover who is leaving at dawn announces that he has to find his fan and his paper ... Finally he discovers the objects. He thrusts the paper into the breast of his robe with a great rustling sound; then he snaps open his fan and busily fans away with it. Only now is he ready to take his leave. What charmless behaviour! "Hateful" is an understatement ... A good lover will behave as elegantly at dawn as at any other time. He drags himself out of bed with a look of dismay on his face ... he comes close to the lady and whispers whatever was left unsaid during the night ... Presently he raises the lattice, and the two lovers stand together by the side door while he tells her how he dreads the coming day, which will keep them apart; then he slips away. The lady watches him go, and this moment of parting will remain among her most charming memories. ${ }^{66}$

Shōnagon concludes, 'one's attachment to a man depends largely on the elegance of his leave taking. ${ }^{67}$ By using words such as 'charmless', 'elegantly' and 'charming', Shōnagon not only describes the affair as an aesthetic act, but she makes the description of the affair an aesthetic product in itself, demonstrating the mutuality between affairs and other aesthetic acts. Because the properly conducted affair, as described by Shōnagon, is a thing of beauty, it is, by nature, aesthetic.

Morris suggests, 'the cult of beauty prevented things from lapsing into mere crassness. ${ }^{68}$ It did not do so, however, by preventing crass behaviour, but by turning crass behaviour into beautiful behaviour. I would argue that, being aesthetic acts, affairs were not only an inseparable part of the cult of beauty, but were contributors to and continuers of the cult of beauty. Affairs were simultaneously products and producers of aestheticism. The aristocracy was preoccupied with aestheticism, affairs were aesthetic acts, therefore the aristocracy accepted affairs.

\section{The Unaesthetic Affair}

When void of aesthetic associations, affairs were in danger of becoming repugnant. The relationship between Kashiwagi and Onna San no Miya in The Tale of Genji is an example of an unaesthetic affair, that is, an affair that has few, if any, aesthetic associations and does not conform to aesthetic conventions.

Kashiwagi falls desperately in love with Onna San no Miya, a princess in Genji's care, and cannot resist making her his own:

66 Shōnagon, op. cit., p. 49.

68 Morris, op. cit., p. 234. 
Her Highness had innocently retired to sleep when she detected a man nearby and assumed that it was Genji, but then the man lifted her deferentially down from the bed, and she felt oppressed as though by a bad dream. At last she peered up at him and saw that he was someone else ... she seemed to him very sweet and dear. ${ }^{69}$

Though Onna San no Miya calls out, no one hears her. Kashiwagi tries to persuade her to submit to him, saying, it is not as though this sort of thing has never happened before, and if it is your wish to be so astonishingly cruel, then I shall be very deeply hurt, and blind passion may master me after all. ${ }^{70}$ During the night, Kashiwagi rapes Onna San no Miya. By morning, his railing and her reticence cause both to resent the other. Kashiwagi, disappointed though his desire is assuaged, comes to regret his behaviour and recognises it as abominable, even as a crime, though not in any legal sense of the word. He neglects his wife (who is Onna San no Miya's sister) and lapses into a depression; this causes his wife to also lapse into a depression. Eventually he goes off his food and dies of starvation. Onna San no Miya, meanwhile, is plagued with shame and eventually gives birth to Kashiwagi's child, the aforementioned Kaoru.

Kashiwagi, not bound to be loyal to his wife, has the liberty to love, and lust after, other women. Because rape as we know it was sanctioned, his violating of Onna San no Miya is not a criminal act. Onna San no Miya feels guilt because she is enticing by nature and, while she is required to submit to those men who cannot, like Kashiwagi, refuse her, she is also accountable for her own violation. Ultimately, Onna San no Miya should never have allowed herself to be seen, for, in revealing herself, she ran the risk of rousing the natural passions of men.

I would suggest that, while not criminal in the Heian period, affairs of the sort just described were rendered improper due to a lack of accompanying aestheticism. In this example, Kashiwagi fails to approach Onna San no Miya in the appropriate way before entering a relationship with her and he does not behave appropriately afterwards according to prevailing aesthetic standards. What occurs, as a result, is regretful, depressing and chaotic.

Half of Shōnagon's list of 'Shameful Things' is devoted to problems stemming from the inappropriately conducted affair. She writes it is shameful for a man to mislead a woman, to be insincere, to be heartless and to abandon a woman he has impregnated. ${ }^{71}$ That such behaviour should be called 'shameful' is significant, for shame was the very

69 Murasaki, The Tale of Genji, pp. 650-651.

70 Ibid., p. 651.

71 Shōnagon, op. cit., pp. 144-145. 
thing every aristocrat avoided. Nobody wanted to be judged negatively, considered inadequate, or excluded for a perceived shortcoming.

I observe, then, three things about aestheticism. First, aestheticism created parameters for behaviour; that is, it determined how people did and did not act. While aestheticism did not explicitly prohibit behaviour such as Kashiwagi's, it did cause such behaviour to be viewed negatively. By causing certain behaviour to be viewed negatively, aestheticism implicitly promoted certain modes of behaviour. Second, aestheticism threatened penalties to those who did not act within aesthetic parameters. The penalties were not corporeal or capital punishment, but shame, embarrassment, mockery and gossip. Aestheticism caused people to be extremely self-conscious and, if not competitive, then at least comparative, as can be seen in the extracts from Murasaki's diary regarding clothing. People who did not conform or adhere to the prevailing aesthetic, who did not exhibit taste and pathos, opened themselves to criticism or ridicule by their peers. Third, by imposing consequences for unaesthetic behaviour, aestheticism ensured the Heian aristocracy was homogenous, that is, that members of the Heian aristocracy all spoke, behaved and interacted in a particular manner. By homogenising aristocratic society, aestheticism also closed and defined aristocratic society. Aestheticism identified aristocrats and separated them from commoners; it ensured there was no confusing the two communities. The affair, then, that adhered to aesthetic convention was legitimate, and while the affair that did not was not criminal in the legal sense, it was, like Kashiwagi's dealings with Onna San no Miya, distasteful, shameful and potentially disgraceful. Acceptance, even prestige, came through avoiding such behaviour.

\section{The Unaesthetic Aesthetic Affair}

Even when conducted within aesthetic parameters, affairs were not always the things of beauty they ideally should have been. Like marriage, affairs had the potential to bring great dissatisfaction to the parties involved. In 'When a Court Lady is on Leave', Shōnagon describes how uncomfortable it is for a woman to receive a man when on leave from court. ${ }^{72}$ If her lover arrives, a woman feels obliged to let him in, but they can have no peace, for the owner of the house and his servants make the situation uncomfortable. Even when at the palace and in familiar surroundings with familiar company, receiving a lover could be difficult. In her list of 'Hateful Things', Shōnagon includes: 'An admirer has come on a clandestine visit, but a dog catches sight of him and starts barking. One feels like killing the beast. One has been foolish enough to invite a man to spend the

72 Ibid., pp. 182-184. 
night in an unsuitable place - and then he starts snoring. ${ }^{73}$ In both of these cases, the 'hateful thing' is the risk of discovery. Fear of exposure surely decreased the enjoyment of affairs for some.

Waiting for a lover could be just as uncomfortable as receiving a lover, especially when the waiting proved in vain. Shōnagon, in her list of 'Depressing Things', includes:

It is quite late at night and a woman has been expecting a visitor. Hearing finally the stealthy tapping, she sends her maid to open the gate and lies waiting excitedly. But the name announced by the maid is that of someone with whom she has absolutely no connection. Of all the depressing things this is by far the worst. ${ }^{74}$

The Mother of Michitsuna similarly waits, night after night, for Kaneie but, night after night, he fails to show. She, better than anybody, describes just how 'depressing' such an experience was. The Mother of Michitsuna, however, may have expected too much from Kaneie, given her rank in relation to his. Though she is recorded as one of the three great beauties of her day, the Mother of Michitsuna was not of sufficient rank to deserve Kaneie's constant attention. ${ }^{75}$ A man, like Kaneie, with many lovers, necessarily had to neglect some in order to please others. ${ }^{76}$ The mark of a good lover, then, was his ability to treat all his women as they deserved, with regard to their rank and their birth, and without partiality or discrimination. ${ }^{77}$

The matter of depression (a term not to be interpreted pathologically) is a curious one, for Heian aestheticism encouraged depression or, more accurately, a delicate pathos and appreciation of the transience of life and the world. The world, to the Heian aristocrat, was viewed as a place of suffering; it was not a place of happiness. Because affairs and aestheticism were inseparable, it follows that if aestheticism was characterised by a melancholic nature, then so too were affairs. Affairs, as a form of aesthetic expression, exhibited the nature of Heian aestheticism:

Expressing depression was also an aesthetic convention, for it was a way of demonstrating sensitivity. Upon parting, for example, lovers frequently expressed their grief at the prospect of separation or solitude. Also, an exchange of poems between the Mother of Michitsuna and Kaneie's sister, Lady Jōganden, reads like a competition over who is suffering the most from their relationship. ${ }^{78}$

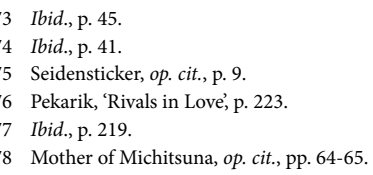


Seidensticker, in his introduction to The Gossamer Years, attributes the intensity of female suffering to Heian marriage institutions and the constitution of the Heian lady: 'the uncertainty of a badly articulated system of polygamy must have been intense. The insanity of Higekuro's wife in the Tale of Genji and the hysterical jealousy of Michitsuna's mother were perhaps common manifestations of the strain on the mind of the delicate Heian lady. ${ }^{79}$ Jealousy, epitomised in the Mother of Michitsuna, is mentioned by several Heian scholars. Tonomura, for example, suggests that jealousy in the Konjaku collection, 'is strictly a feminine attribute; the term is never used in respect to men, and there are no tales that explicitly discuss male jealousy, although male jealousy is illustrated at work. ${ }^{80}$ Men were freed from jealousy for they could have whomever they pleased; women, though, were prone to jealousy for they were not afforded the power over sexual relations that men were. Jealousy and anxiety, then, are inseparable, for if ever one woman was jealous of another, she was certainly also anxious that her lover would not permanently replace her with a rival. Morris describes the Heian woman as occupying a precarious position, uncertain of her lover's affection, uncertain of her own future and fearful of rumours and abandonment. ${ }^{81}$ According to Morris, dependence on men and a desire for security produced tension in the Heian woman and made it difficult for her to deal with complications resulting from the polygamous system. ${ }^{82}$

Morris's approach to the psychology of the Heian noblewoman resembles the Annalistes approach to emotions. Annalistes see emotional trauma as resulting from mental and physical insecurity. ${ }^{83}$ More recently, it has been suggested the historian must look to a society's rules of conduct to better understand expressions of emotion within that society. Societies determine what are and are not appropriate forms of emotional expression, thus determining how people within that society react. ${ }^{84}$ Barbara Rosenwein, who has reviewed the approaches to emotions in history, suggests the historian must uncover, among other things, how a community expects emotions to be displayed and how a community evaluates the emotions of other communities. ${ }^{85}$ She further suggests that people move between communities and adjust their emotional responses accordingly. ${ }^{86}$

By adopting Rosenwein's approach, the jealousy and hysteria expressed by Heian women changes from a reaction to insecurity, as Morris and Annalistes might suggest, to a socially sanctioned act. The extent, then, to which Heian women reacted to their

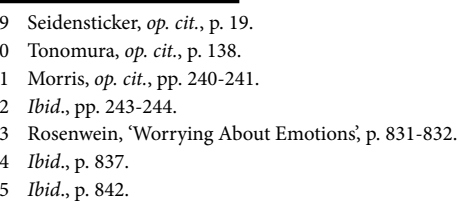


position may not reflect the extent of their insecurity and inner turmoil, but the liberality of their community when it came to expressing emotion. The Mother of Michitsuna, then, expresses her jealousy and disappointment so effusively not because her situation is drastically worse than that of any other woman in Heian Japan, but because her community perceives such effusiveness to be an appropriate mode of emotional expression.

\section{Conclusion}

In Heian-period Japan, relationships between men and women, which Shōnagon ambiguously describes as near but distant, most frequently took the form of extramarital affairs. The unquestioned existence and sheer prevalence of affairs in the Heian period was supported by the nature of the marriage institutions, by perceptions of sexuality, by Shinto and Buddhism, and by aestheticism. The marriage institutions, and the living arrangements involved, facilitated a physical and emotional distance between husbands and wives. Matrimony did not foster loving relationships, therefore people sought love outside marriage. Marriage was also less of an aesthetic outlet than affairs.

Affairs were facilitated by men's sexual freedom. Men were perceived to have natural desires they could not resist, while women were perceived to be naturally desirable and irresistible. Both men and women were expected to engage in affairs; the sexually inactive person could be accused of being unhuman. Such an outlook not only encouraged affairs but, importantly, justified them, even when their nature was akin to rape. Heian religion further encouraged and justified affairs. Shinto saw sex as a positive act, while Buddhism, in viewing all sexual acts as products of desire and hindrances to Buddhahood, rendered affairs as valid as matrimonial relations.

Aristocrats embraced and perpetuated affairs because affairs were aesthetic acts and the aristocracy had a penchant for aestheticism. Affairs were at once products and continuers of aestheticism. While, then, aestheticism informs our understanding of affairs, affairs also inform our understanding of aestheticism. I observe aestheticism acting in three ways in the Heian period. Aestheticism set parameters for behaviour; affairs that fell outside these parameters had a negative character. Bad behaviour led to gossip and mockery, therefore aestheticism set penalties for transgressors. By setting parameters and imposing penalties, aestheticism also homogenised the Heian aristocracy. Even the affair that existed within aesthetic parameters, however, was not always a source of enjoyment. Affairs, being aesthetic acts, bore the general nature of Heian aestheticism, which was largely melancholic. The expression of depression, though, while potentially genuine, was also a way of demonstrating pathos and an accepted emotional outlet in Heian-period Japan. 
New Voices Volume 3

\section{References}

Dalby, L., Kimono: Fashioning Culture (London: Vintage, 2001).

Goodwin, J. R., Selling Songs and Smiles: the Sex Trade in Heian and Kamakura Japan (Honolulu: University of Hawaii Press, 2007).

Hurst, G. C., III. 'Kugyō and Zuryō: Center and Periphery in the Era of Fujiwara no Michinaga', in Adolphson, M., Kamens, E. and Matsumoto S. (eds.), Heian Japan, Centers and Peripheries (Honolulu: University of Hawaii Press, 2007), pp. 66-101.

McCullough, W. H., 'Japanese Marriage Institutions in the Heian Period', Harvard Journal of Asiatic Studies, vol. 27 (1967), pp. 103-167.

McCullough, W. H., 'The Capital and its Society', in Shively, D. H. and McCullough, W. H. (eds.), The Cambridge History of Japan, Volume 2, Heian Japan (Cambridge: Cambridge University Press, 1999), pp. 97-182.

Morris, I., The World of the Shining Prince: Court Life in Ancient Japan (New York: Kodansha America, 1994).

Mother of Michitsuna, The Gossamer Years: The Diary of a Noblewoman of Heian Japan, Seidensticker, E. (trans.) (Tokyo: Tuttle Publishing, 1964).

Murasaki Shikibu, The Diary of Lady Murasaki, Bowring, R. (trans.) (London: Penguin Books, 2005).

Murasaki Shikibu, The Tale of Genji, Tyler, R. (trans.) (New York: Penguin Books, 2003).

Nijō, Lady, The Confessions of Lady Nijō, Brazell, K. (trans.) (Stanford: Stanford University Press, 1973).

Pandey, R., 'Poetry, Sex and Salvation: The "Courtesan" and the Noblewoman in Medieval Japanese Narratives', Japanese Studies, vol. 24, no. 1 (2004), pp. 61-79.

Pekarik, A., 'Rivals in Love', in Pekarik, A. (ed.), Ukifune: Love in The Tale of Genji (New York: Columbia University Press, 1982), pp. 217-230.

Rosenwein, B. H., 'Worrying About Emotions in History', The American Historical Review, vol. 107, no. 3 (2002), pp. 821-845.

Sanae, F. and Watanabe, T., 'From Female Sovereign to Mother of the Nation: Women and Government in the Heian Period', in Adolphson, M., Kamens, E., and Matsumoto, S. (eds.), Heian Japan, Centers and Peripheries (Honolulu: University of Hawaii Press, 2007), pp. 15-34.

Sansom, G., A History of Japan to 1334 (Stanford: Stanford University Press, 1967).

Sei Shōnagon, The Pillow Book of Sei Shōnagon, Morris, I. (trans.) (London: Penguin Books, 1971).

Shirane, H., 'The Uji Chapters and the Denial of the Romance', in Pekarik, A. (ed.), Ukifune: Love in The Tale of Genji (New York: Columbia University Press, 1982), pp. 113-138.

Tonomura, H., 'Black Hair and Red Trousers: Gendering the Flesh in Medieval Japan', The American Historical Review, vol. 99, no. 1 (1994), pp. 129-154.

Varley, P., Japanese Culture, $4^{\text {th }}$ ed. (Honolulu: University of Hawaii Press, 2000).

Walshe, M. O'C., Buddhism and Sex (Kandy: Buddhist Publication Society, 1975). 


\title{
Learners' Participation in Informal Japanese-English Internet Chat
}

\author{
Sarah Pasfield-Neofitou
}

Monash University

\begin{abstract}
It has been widely claimed that computer mediated communication offers unique opportunities for language learners, including the ability to take on the roles of 'writer' and 'reader', 'teacher' and 'learner'. Hence, it is important for teachers and learners to be aware of not only the linguistic and interactional characteristics of especially bilingual chat, but also how participants in an intercultural setting may switch between roles. Learning about one's second language from a peer, and in turn, teaching that peer about one's native language may allow both participants opportunities to develop as language experts. This article utilises naturalistic bilingual chat data and follow-up interviews to examine the implications of these findings for learners, teachers and researchers.
\end{abstract}

\section{Keywords}

CMC, SLA, bilingual, chat

\section{Introduction}

The spread of the Internet has led to an increase in its use for educational purposes both inside and outside the classroom. Throughout the developed world, language students are now able to communicate with their peers in a target-language speaking country from almost anywhere, at any time. Accordingly, it has been widely claimed that computer mediated communication (CMC) including synchronous or 'real time' electronic chat programs such as 'MSN Messenger', where users compose text-based messages to one another, offer unique opportunities for language learners. ${ }^{1}$ These opportunities include the ability to communicate relatively cost-effectively with native speakers, despite geographic separation, both from inside the classroom and from home. This is of particular importance to students of Japanese as a Foreign Language (JFL) who may find opportunities to meet native-speaking peers difficult or impossible otherwise, yet there is a real lack of research on students' out-of-classroom communication using

1 MSN Messenger is a chat program distributed for free by the Microsoft Corporation. It has now been re-branded 'Windows Live Messenger'. Downloads are available in a number of languages from http://get.live.com/messenger/overview. 
CMC. Furthermore, few studies to date have employed introspective methodology like the follow up interview to attain greater ecological validity by providing insight into 'offscreen' activity and thought processes.

One of the main themes reiterated throughout particularly the early literature on synchronous CMC is the 'egalitarian' nature of chat. This often-cited benefit of 'equal participation' is based on the fact that synchronous CMC has what are perceived as 'fairer' rules that govern turn-taking than face-to-face communication, as the turns of all participants are treated as equal by the regulating software. ${ }^{2}$ Yet the simple fact that a learner's message is received and displayed on the screen by the computer does not mean that it is read and valued by their interlocutor. Furthermore, while the regulating software may treat each utterance the same, participation is highly influenced by the participant's computer literacy (including typing speed), Internet connection speed, and many personal factors, such as their relationship with their chat partner, the way in which the interlocutors frame the activity of chatting, and the individual roles they adopt in the course of communication.

It is argued by many researchers that the 'egalitarian' nature of chat is the cause of increased language usage, particularly among shyer participants. For example, Kelm found that computer-aided class discussion increased the language use of learners of Portuguese. ${ }^{3}$ This finding was supported by Kern, who discovered that chat offered more frequent opportunities for student expression than face-to-face interaction. ${ }^{4}$ Kern also found that students' language output was of a more sophisticated level in chat than in face-to-face discussion on the same topic, in terms of morphosyntactic features and the variety of discourse functions.

Warschauer also tested the claim that CMC can result in more equal participation among learners than face-to-face discussion, by studying the interaction of advanced ESL students in a Hawaiian university. ${ }^{5}$ The four quietest members of the class in the face-to-face discussions, all Japanese, increased their production almost ten-fold, going from $1.8 \%$ of all utterances to $17.3 \%$. This result appears very encouraging for learners who experience shyness in face-to-face situations.

While early work concentrated on statistics, in terms of the number of utterances or features produced, researchers have become increasingly interested in

\footnotetext{
2 Kelm, 'The Use of Synchronous Computer Networks in Second Language Instruction: A Preliminary Report', pp. 441 - 545; Kern, 'Restructuring Classroom Interaction with Networked Computers: Effects on Quantity and Characteristics of Language Production', pp. 457 - 76; Warschauer, 'Comparing Face-to-Face and Electronic Communication in the Second Language Classroom', pp. 7 - 26.

3 Kelm, op. cit.

4 Kern, op. cit.

5 Warschauer, op. cit.
} 
identity and participant roles, especially within sociocultural approaches. Among others, Herring has investigated power issues and turn taking in CMC, particularly in regards to gender stereotypes. ${ }^{6}$ Abrams compared the participant roles of students of intermediate German in classroom-based writing and CMC discussion, and found that learners adopted a wider variety of roles in the CMC discussions. ${ }^{7}$ Attacker, challenger, joker and supporter were all roles found in the class-based CMC discussions, but not in the group journals students jointly composed.

The body of work carried out on tandem learning via CMC is also relevant to the examination of teacher/learner roles in chat. Drawing on Sociocultual Theory, Chung, Graves, Wesche and Barfurth undertook a longitudinal case study of the Korean- and English-speaking peers studying each others' languages who were paired up for the purpose of language learning. ${ }^{8}$ It was found that participants took turns in the roles of 'expert' and 'novice', engaging in reciprocal teaching, supporting one another's language learning. Kötter also examined online tandems, observing a mandatory language exchange between classes at a German and North American university. ${ }^{9}$ In order to ensure successful tandem learning, Kötter argues that it is important for each partner to be prepared to adopt the role of 'expert' for their linguistic and cultural community.

Despite recognition of the importance of participant roles in CMC tandem learning and the multitude of opportunities CMC provides for authentic communication with native speakers outside the classroom, it is unclear how effectively learners adopt these roles outside the institutional sphere. It appears that little research has been conducted to examine the different roles adopted by students 'in the wild', away from teachers and the classroom, and the ways that their framing of the activity influences conversational outcomes when conversing with native speakers. Furthermore, despite the multitude of claims that one of the Internet's main benefits is increased support for autonomous study and language acquisition outside the classroom, there is a lack of empirical evidence to support this claim. Very little research has been conducted of naturalistic settings, outside the classroom, where learners are free to interact with whomever they choose, in the language of their choice, rather than being paired with a fellow learner or subject. In fact, Tudini found that some students engaged in learner-only chat in the classroom complained that they wanted "someone they could learn from". ${ }^{10}$ Accordingly, the aim of this

\footnotetext{
6 Herring, 'Gender and Democracy in Computer-Mediated Communication'; Herring (ed.), Computer-Mediated Communication: Linguistic, Social and Cross-Cultural Perspectives. Pragmatics and Beyond; Herring, 'Interactional Coherence in CMC'; Danet and Herring, 'Introduction'.

Abrams, 'Computer-Mediated Communication and Group Journals: Expanding the Repertoire of Participant Roles', pp. 489-503.

Chung et al., 'Computer-Mediated Communication in Korean-English Chat Rooms: Tandem Learning in an International Languages Program', pp. 49 - 86.

Kötter, 'Negotiation of Meaning and Codeswitching in Online Tandems', pp. 145 - 72.

10 Tudini, 'Using Native Speakers in Chat', pp. 141 - 63.
} 
paper is to investigate the in situ out-of-classroom patterns of chat participation of Japanese and English second-language learners in naturalistic settings, in the form of two research questions:

1. What role shifts between, for example, teacher and learner, do learners' patterns of CMC use indicate?

2. What factors influence who dominates the conversation?

In order to obtain a naturalistic picture of students' out-of-class bilingual online communication, no restrictions were placed upon the participants in this study. They were free to use chat at home, on campus, indeed, from any location, and to converse with a native-speaking peer of their choice (former host sister, classmate, language exchange partner), whenever and about whatever they like, and in whatever language they like.

\section{Research Methodology}

\section{Participants}

Five advanced students of Japanese (four female one male), enrolled in the top two (out of six) levels of Japanese language at an Australian university volunteered to participate in this study. Each had in-country experience in Japan, and had used chat in the past. All five Australian students are native speakers of English. In turn, they were each asked to invite the participation of a Japanese native speaker with whom they regularly used chat. All of the Japanese participants (four female one male) were native speakers of Japanese, advanced users of English (with eight to 14 years prior study), and had visited Australia. All five also had prior chat experience. It is important to note that, unlike many previous studies, the Japanese participants in this study were not fellow students that the Australians had been paired with by the researcher, but were friends and acquaintances of the Australian participants, with whom they had established relationships prior to the commencement of this study.

A total of ten participants participated in this study. Each pair had an established relationship prior to the commencement of data collection. Kaylene and Ruriko were language exchange partners at the same university, Phia and Soichiro were former classmates and kept in contact via chat after Soichiro returned to Japan, Jacob and Miku were social chatters who met through a mutual friend online, Evelyn and Azusa were former host sisters after Evelyn participated in a high-school exchange, 
and Nadia and Tomi were education students at the same university who met through Tomi’s flatmate. All names given are pseudonyms.

\section{Data collection}

At the time of data collection, MSN Messenger was the most popular instant messaging (chat) program in both Japan and Australia. Australian participants were asked to set the program to automatically record their chat conversations over the course of a month. The files created by this recording are called chat logs, and record the date, time, sender and recipient, as well as the content, of each message (see Figure 1).

\begin{tabular}{|c|c|c|c|c|}
\hline Date & Time & From & To & Message \\
\hline $5 / 02 / 2006$ & $11: 00: 04 \mathrm{PM}$ & Everyday Seraph & $\begin{array}{c}\text { Soichiro@ } \\
\text { Tsukuba }\end{array}$ & $\begin{array}{c}\text { こんばんは! } \\
((\text { Good evening!) })\end{array}$ \\
\hline $5 / 02 / 2006$ & $11: 00: 46 \mathrm{PM}$ & $\begin{array}{c}\text { Soichiro@ } \\
\text { Tsukuba }\end{array}$ & Everyday Seraph & $\begin{array}{c}\text { こんばんわ! 元 } \\
\text { 気にてます } \\
\text { か? } \\
\left(\begin{array}{c}\text { (Good evening! } \\
\text { Are you well? }))\end{array}\right.\end{array}$ \\
\hline
\end{tabular}

Figure 1. Sample excerpt from chat log from MSN Messenger between Phia (Everyday Seraph) and Soichiro, with English translation.

The process required to save chat conversations is relatively unobtrusive, taking only a matter of seconds. Furthermore, most participants were already using this feature, and several pairs including Kaylene and Ruriko, Evelyn and Azusa, and Phia and Soichiro were able to provide the researcher with chat logs dating back to before the commencement of the research project. Such archived records are particularly important, as they can aid in uncovering to what extent any 'observer effect' may have occurred once participants were conscious that their conversations would be analysed. No major differences in terms of language use, participant roles, and so on were found between the chat logs recorded prior to the recruitment process, and those recorded during the data collection period. It is important to note that while participants were unaware at the time of these earlier chat conversations that their communication would later be analysed, all data was provided voluntarily, and the participants were fully aware of the aims and procedures of the research project before any data was collected from them.

The earliest data obtained was from Phia and Soichiro, giving a total data collection period of almost five months for this pair. A total of 10 chat conversations were 
recorded by participants and provided to the researcher (three from each of Kaylene and Ruriko and Evelyn and Azusa, two from Phia and Soichiro, and one conversation from the other two pairs).

At the end of the one-month period, the Australian participants emailed the chat logs produced from their conversations with their Japanese partners to the researcher for discussion and analysis. Of the chat logs collected, one consisted of an attempted conversation, in which Evelyn tried, and failed, to get Azusa to participate. Follow-up interviews were conducted with both the Japanese and Australian participants in order to gain insight into participants' off-screen behaviour during the chat conversation. A follow-up interview with each Japanese participant was conducted via chat within minutes of their most recent interaction with their Australian chat partner. The chat log from this conversation was then kept for analysis also. As soon as possible after the follow-up interview with the Japanese participant, sometimes immediately after, sometimes the next morning in the case of a late night chat, a face-to-face follow-up interview was conducted with the Australian participant. Interviews were digitally recorded in wav format, and a back up was recorded simultaneously. Interviews were then transcribed using simplified Conversation Analysis conventions.

According to Nunan, introspection is the process of observing and reflecting upon one's mental state. ${ }^{11}$ A follow-up interview, as defined by Neustupný, is an interview ideally conducted immediately after the recording session, in which each participant is interviewed separately, and asked a set of questions to help establish their awareness of various processes, and as such, can only reveal processes of which the participants are aware. ${ }^{12}$ A further set of questions concerning the particulars of language use by the participant or their interlocutor was also asked. Accordingly, the follow-up chat interview conducted with the Japanese participants consisted of two sections, general questions on the participant's chat usage and English study, and specific questions on the most recent chat interaction. Stimulated recall, an introspective method where the participant can refer to a record of their interaction while describing their thought processes at the time of the activity was used in the second section of the chat interview. ${ }^{13}$ Segments of the chat log were produced, by cutting and pasting from the original chat log, and questions adapted from the guidelines of Neustupný and Miyazaki were asked. ${ }^{14}$ Questions in this section of the interview were of a very general nature, ranging from 「どう感じましたか」(“How did you feel?”) to 「どう思いまし たか?」 ("What did you think?”). The face-to-face follow-up interview with the

1 Nunan, Research Methods in Language Learning.

12 Neustupný, 'The Follow-up Interview', pp. 31 - 33.

13 Gass and Mackey, Stimulated Recall Methodology in Second Language Research.

14 Neustupný and Miyazaki, Gengo Kenkyū No Hōhō (Techniques for Language Research). 
Australian participants consisted of the same general questions about the participants' chat usage and Japanese study, then the interviewee was shown a printed copy of their most recent chat log, about which questions again based on Neustupný, and Neustupný and Miyazaki were asked.

\section{Analysis Method}

The methodology employed draws upon the framework of Thorne's examination of French language CMC use. ${ }^{15}$ As discussed above, the primary sources of data for this study consist of transcribed spoken texts (the follow-up interviews) and written texts (the chat logs from both the dyadic chat interactions and the chat follow-up interviews). The first, historical section of the follow-up interviews was analysed using Sociocultural Theory as the overall interpretative framework. The term sociocultural refers to a marriage of social and cultural factors, but Sociocultural Theory (SCT) invokes a specific association with the cultural-historical work of Lev Vygotsky, the influential Russian psychologist who put forward the key concepts of the Zone of Proximal Development, scaffolding, psychological tools and mediation, and internalisation. ${ }^{16}$ The goal of sociocultural research is to understand the relationship between human mental functioning and cultural, historical and institutional setting. A vital feature of Vygotsky's view of learning is that it is embedded in social and interactional events within the environment, such as the chat conversations examined in the present study.

Sociocultural Theory, and in particular the branch Activity Theory, emphasises that learning is the product of social interaction, and that higher, culturally constructed forms of thinking are reliant upon mediation. Vygotsky first advanced a model of mediated action which included the subject, their object of activity, and the artefact, or mediating tool. Later, Engeström proposed a more complex model to capture societal as well as cultural dimensions, such as communities, the rules that structure them, and the division of labour. ${ }^{17}$ The division of labour refers to both the horizontal actions and interactions among the members of the community and the vertical divisions of power and status, for example between teachers and students. Division of labour and power will be referred to in this sense in the present study.

Engeström's model is reproduced below (see Figure 2) ${ }^{18}$, infixed with the specifics of the present study. At the base of this model, the social framework of human activity

15 Thorne, 'An Activity Theoretical Analysis of Foreign Language Electronic Discourse'.

16 Vygotsky, Thought and Language; Vygotsky, Mind in Society; Vygotsky, 'The Development of Higher Forms of Attention in Childhood.

17 Engeström, 'Activity Theory and Transformation'.

18 Ibid., p. 31. 
is depicted, while the upper part represents Vygotsky's original conceptualisation of mediated goal directed activity. In Engeström's structure of a human activity system, the uppermost level of activity is driven by an object related motive, the middle level, action, by a conscious goal, and the bottom level consists of automatic operations driven by the conditions and tools of the action at hand.

Mediating artefacts Computers

Internet

English and Japanese languages
Subject Australian \& Japanese chat participants

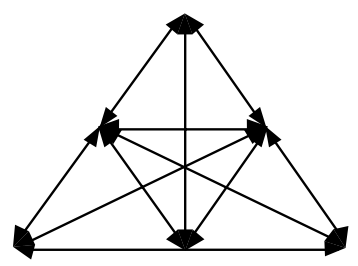

Community Pairs Other communities
Rules Rules of chat Individual rules established by pairs

\section{Object \\ Communication \\ Language learning \\ Division of}

Labour

Pair positions

Other positions

FIGURE 2. Engeström's Activity System, infixed with the specifics of the present study.

Sociocultural Theory is useful in interpreting the interviews in terms of participants' individual histories and social backgrounds as they relate to their communicative practices. Meanwhile, the participants' communicative activity (as recorded in the chat logs and informed by the second section of the interview) was analysed using a modified version of Sacks, Schegloff and Jefferson's Conversation Analysis, as advanced by Thorne. ${ }^{19}$

The unit of analysis utilised for the micro analysis of the chat logs was the 'e-turn', coined by Thorne. 'E-turns' are derivative of a turn unit, as defined by Sacks, Schegloff and Jefferson ${ }^{20}$. While a turn may be defined as ending each time the floor is transferred from one participant to another, in the context of MSN Messenger, or similar instant messengers, an 'e-turn' is a distinct block of text that is tagged with the sender's name (see Figure 3). 


\begin{tabular}{|c|c|c|c|}
\hline $28 / 04 / 2006$ & 11:13:33 PM & Nadia & $\begin{array}{l}\text { ああ そうですか。 何をべんきょうし } \\
\text { ていますか。 } \\
\text { ((Ah really? What are you studying?)) } \\
\end{array}$ \\
\hline $28 / 04 / 2006$ & 11:15:53 PM & Stomi $\delta$ & $\begin{array}{l}\text { 今は、bridging courseで勉強をしていて、 } \\
7 \text { 月から、TESOLのDIPLOMAを勉強する } \\
\text { 予定です。 } \\
\text { ((Now, I'm studying a bridging course, and from } \\
\text { July I plan to study for a TESOL diploma.)) }\end{array}$ \\
\hline $28 / 04 / 2006$ & 11:16:45 PM & $\delta$ tomi $\delta$ & $\begin{array}{l}\text { bridging courseは、大学院に入るための } \\
\text { fundamental courseです } \\
\text { ((The bridging course is a fundamental course in } \\
\text { order to enter graduate school. }))\end{array}$ \\
\hline $28 / 04 / 2006$ & 11:17:45 PM & Nadia & $\begin{array}{l}\text { ああ 分かります。私も モナッシュで } \\
\text { 勉強しています。日本語とESLの先生にな } \\
\text { りたいです。今Diploma of Education を勉 } \\
\text { 強してます。 } \\
\text { ((Ah I see. I am also studying at Monash. I want } \\
\text { to become a teacher of Japanese and ESL. Now, } \\
\text { I'm studying a Diploma of Education.)) }\end{array}$ \\
\hline
\end{tabular}

FIgURE 3. Example of a turn and an e-turn in a conversation between Nadia and Tomi.

In this way, a single turn may consist of more than one e-turn. Often, chat users may break a lengthy turn into a series of brief e-turns in order to maintain the interest of their interlocutor. An e-turn is completed by hitting either the 'send' button or the 'enter' key after typing an utterance.

\section{Analysis}

\section{Turn-taking and Conversational Strands Management}

Turn management is one of the fundamental rules of chat conversation. The supposed lack of turn-taking competition in chat has been claimed as evidence of its egalitarianism. Researchers such as Kitade, ${ }^{21}$ Toyoda and Harrison, ${ }^{22}$ Fujiike, ${ }^{23}$ and Fitze,${ }^{24}$ have claimed that turn-taking competition in chat does not occur because overlaps and interruptions are impossible. However, in MSN Messenger, like other chat programs, the order of turns is influenced by the respective typing speed of the participants, the connection speed of their computers, and the way in which the program receives and orders input.

\footnotetext{
1 Kitade, 'L2 Learners' Discourse and SLA Theories in CMC: Collaborative Interaction in Internet Chat', pp. 143 - 66.

2 Toyoda and Harrison, 'Categorization of Text Chat Communication between Learners and Native Speakers of Japanese', pp. 82 - 99.

3 Fujiike, 'Collaborative Interaction in EFL Web-Based Debates: How Do Learners Develop Socially Constructed Knowledge?'.

24 Fitze, 'Discourse and Participation in ESL Face-to-Face and Written Electronic Conferences', pp. 67 - 87.
} 
Furthermore, participants' sociocultural backgrounds, as revealed in the follow-up interview, also influence turn-taking and conversational dominance. Thus, the order of turns can sometimes become jumbled, where adjacency pairs, even if typed in that order, do not necessarily appear adjacent on the screen. For this reason, it appears important that chat participants utilize strategies for managing e-turns.

In the example below, the participants manage three different strands or threads of conversation simultaneously. The lines labelled ' 1 ' and joined by the grey solid line according to Kaylene, are "talking about the camera", in which Kaylene organised with her Japanese language exchange partner Ruriko via chat to use the Internet to contact friends and family in Japan using a webcam at Kaylene's house. The second topic, labelled ' 2 ' and joined by the black solid line, is about it being "so cool how they can email phones in Japan", and the final topic, labelled ' 3 ' and joined by the grey dotted line, is organising a day and time to use the webcam. While all of the topics are related, the turn adjacency is interrupted, with answers to questions, responses to comments and queries about statements delayed, occurring one to two turns later (see Figure 4).

\begin{tabular}{|c|c|c|}
\hline Time & From & Message \\
\hline $18: 23: 03 \mathrm{PM}$ & kay miró & Is that enough time to let people in Japan know you'll be online? \\
\hline $28: 23: 19 \mathrm{PM}$ & kay miró & oh, I forgot... you can email their phone, right? \\
\hline $38: 23: 25 \mathrm{PM}$ & 瑠璃子 & あ、母の日だけど仕事ある？？ \\
\hline & $(($ Ruriko $))$ & ((Ah, it's Mother's Day but do you have work??)) \\
\hline $28: 23: 41 \mathrm{PM}$ & kay miró & かつこいいね \\
\hline & & $(($ It's cool $))$ \\
\hline $18: 24: 03 \mathrm{PM}$ & 瑠璃子 & yes!! maybe it is ok!! \\
\hline $28: 24: 14 \mathrm{PM}$ & 瑠璃子 & What is cool?? \\
\hline 3 8:24:17 PM & kay miró & いいえ、バイトはあしたと土曜日だけ:) \\
\hline & & $(($ No, my part time job is only on tomorrow and Saturday :) )) \\
\hline $28: 24: 32 \mathrm{PM}$ & kay miró & being able to email people’s phones is cool $\wedge \wedge$; \\
\hline 3 8:24:57 PM & 瑠璃子 & Oh, nice!! So what time are you free?? \\
\hline $28: 25: 01 \mathrm{PM}$ & 瑠璃子 & Ah, I got it!! \\
\hline 3 8:25:34 PM & kay miró & anytime you like. I'll probably just being doing homework that day. \\
\hline
\end{tabular}

FIGURE 4. Turn management in language exchange partners Kaylene and Ruriko's chat. 
Kaylene described her management of turns, commenting, "I'm just so used to doing that in chat, because in English, I do that all the time as well, and sometimes we have three conversations going at the same time". She explained that "it's because typing takes a long time, and generally, while the other person's reading, you're saying something else anyway, and so, you end up replying to a comment, then typing one out, then replying to one". She also commented on the short-lived nature of these multiple and concurrent conversational strands, stating that "they don't usually last long anyway".

\section{Avoidance of Multiple Conversational Strands and Conversational Dominance}

The management of multiple and concurrent conversational strands did not occur in all conversations. Jacob described how he avoids multiple "streams of conversation" in chat, by monitoring the space at the bottom of the chat window, which would display "Miku is typing a message" when his partner was composing a turn. "I'd go to write something in, but it would say underneath, Miku is typing, and so I'd go, oh, okay, and delete what I was going to say, because I'd wait for her response". "Because often when... you're both... starting off a question, it'll get really confusing. So I thought, it's probably easier, just to have one stream of conversation going".

In the example below, Jacob began composing another e-turn to complete his turn, directly after his "your english is great" message, but noticed that Miku was typing, deleted his response, and waited almost two whole minutes to read what she had written, in an effort to avoid multiple streams or strands of conversation occurring.

\begin{tabular}{|l|l|l|}
\hline Time & From & Message \\
\hline 10:08:00 PM & Mr Enclosed & your english is great \\
\hline 10:09:59 PM & Miku & $\begin{array}{l}\text { my english has been gettin worse every year!! i did plitical } \\
\text { philosophy last semester n i bought lots of books related to } \\
\text { the subject, but i didnt understand at all even in japanese!! }\end{array}$ \\
\hline 10:09:59 PM & Miku & $\begin{array}{l}\text { 日本語難 しい } \\
\text { ((Japanese is difficult)) }\end{array}$ \\
\hline
\end{tabular}

FIGURE 5. Avoidance of multiple strands in social chatters Jacob (Mr. Enclosed) and Miku’s chat.

It is clear that while it may be impossible to interrupt a chat partner mid e-turn, it is certainly possible to interrupt the flow of conversation mid-turn, between two e-turns. Furthermore, not only is overlap possible in that both participants may compose a message at the same time, when the chat program displays the announcement, "Miku is typing a message" or similar, it is possible for participants 
to not only notice that overlap is occurring, but to make use of overlap avoidance strategies. Participants' use of these strategies are only apparent through use of the follow-up interview.

When one partner, like Miku, is prepared to manage multiple strands, and the other partner, like Jacob, is actively avoiding multiple strands by monitoring this announcement area on the screen, an imbalance in participation can occur. For this reason, consideration of the nature of a pair's relationship is crucial in analysis. Social chatters Jacob and Miku displayed the biggest discrepancy in terms of e-turns produced, as Jacob reported that he would wait for Miku to finish typing, but Miku would not wait for him. Thus, in their chat conversation Jacob composed and sent only 74 turns (an average of 0.75 turns per minute), in comparison with Miku's 124 (or 1.25 turns per minute), as shown in the table below. Pairs in which both partners reported avoiding multiple and concurrent strands, such as education students, Nadia and Tomi, and former classmates, Phia and Soichiro, were much more balanced in terms of turn-taking. In their conversation, Nadia took 24 turns, an average of 0.4 per minute, and Tomi 19 turns, or 0.32 per min. Phia and Soichiro each took seven lengthy turns in their first conversation, while in their second conversation, Phia took 27 turns, an average of 0.55 per minute, while Soichiro took 35 , an average of 0.71 per minute. They exhibited the slowest pace, producing the lowest number of turns per minute, but on average their turns were much longer (an average of 56.62 characters per turn in their two conversations, compared to the overall average of 26.73 characters per turn). Pairs in which both partners actively managed multiple and concurrent strands, such as language exchange partners Kaylene and Ruriko, and former host sisters Evelyn and Azusa, were also more fair in number of turns taken. Evelyn and Azusa also exhibited a much higher number of turns per minute, which suggests that the style of turn management is directly related to amount of turns participants produce.

\begin{tabular}{|l|l|l|l|l|l|l|l|l|l|l|l|}
\hline & \multicolumn{3}{|l|}{$\begin{array}{l}\text { Education } \\
\text { Students }\end{array}$} & \multicolumn{3}{l}{ Language Exchange } \\
Partners
\end{tabular}




\begin{tabular}{|l|l|l|l|l|l|l|l|l|l|l|}
\hline $\begin{array}{l}\text { MEAN TURNS } \\
\text { PER MINUTE }\end{array}$ & $\mathbf{0 . 7 2}$ & $\mathbf{1 . 1 9}$ & $\mathbf{2 . 0 6}$ & $\mathbf{2 . 1 8}$ & $\mathbf{2 . 0 6}$ & $\mathbf{5 . 4 5}$ & $\mathbf{1 . 0 3}$ & $\mathbf{1 . 9 9}$ & $\mathbf{0 . 3 9}$ & $\mathbf{1 . 2 5}$ \\
\hline English NS & 0.40 & 0.54 & 0.92 & 0.97 & 1.07 & 5.45 & 0.65 & 0.75 & 0.20 & 0.55 \\
\hline Japanese NS & 0.32 & 0.64 & 1.14 & 1.21 & 0.99 & 0.00 & 0.37 & 1.25 & 0.20 & 0.71 \\
\hline $\begin{array}{l}\text { MEAN } \\
\text { CHARACTERS } \\
\text { PER TURN }\end{array}$ & $\mathbf{2 1 . 7 9}$ & $\mathbf{2 7 . 9 9}$ & $\mathbf{2 7 . 4 3}$ & $\mathbf{3 0 . 4 8}$ & $\mathbf{7 . 1 6}$ & $\mathbf{3 . 6 7}$ & $\mathbf{1 3 . 4 1}$ & $\mathbf{2 2 . 2 5}$ & $\mathbf{6 0 . 7 9}$ & $\mathbf{5 2 . 4 5}$ \\
\hline English NS & 21.50 & 33.72 & 34.33 & 34.90 & 7.92 & & 3.67 & 12.06 & 50.57 & 49.30 \\
\hline Japanese NS & 22.16 & 23.15 & 21.91 & 26.91 & 6.33 & & 0.00 & 15.78 & 71.00 & 54.89 \\
\hline
\end{tabular}

FIGURE 6. Number of turns, length of chat in hours and number of characters.

\section{Participant Roles and the Division of Labour}

In intercultural Internet chat conversations, turn-taking may be viewed in terms of the sociocultural concept of a division of labour, as participants complete the actions of both writing and reading messages. In addition, many participants took up the role of the 'teacher', and engaged in reciprocal teaching. In one example, Ruriko asked Kaylene, "What is lol??". Kaylene provided her with the explanation that "lol is an acronym, it means Laugh Out Loud", then continued with an explanation of its usage, "Like the smiley face :) only laughing". The roles of expert and novice are reversed when Kaylene asks Ruriko about the origin of 「なるへそ」(naruheso, I see), which Kaylene believes to be a regional dialect form of 「なるほじ」(naruhodo, I see). Ruriko confirms Kaylene's understanding of the meaning, but explains that it is a littleused "slang" term rather than dialect. She goes on to say in English "It is not formal expression, but it has humor!!".

As the imbalances in turn taking discussed above suggests, there was also sometimes an imbalance in the division of labour. In the language exchange partners pair, where the nature of Kaylene and Ruriko's tandem-like relationship was one based upon the mutual goal of teaching and learning of a second language, the division of labour was fairly even. Both partners produced a similar number of turns, thus the burden of composing and responding to messages was reasonably equal. Furthermore, both Kaylene and Ruriko experienced role shifts from teacher to learner, asking one another questions about language. Instead of only asking about new words directly related to the communication at hand, Kaylene and Ruriko, as language exchange partners, took turns to ask explicit questions on language. Ruriko stated in the chat interview that she and Kaylene knew each other primarily as language exchange partners. In the face-toface interview, Kaylene added that Ruriko often asks her about English phrases "that she wants to try and use, and isn't sure about how to use them". 
One pair in which the division of labour was certainly not even was the former host sisters, Evelyn and Azusa. Evelyn stayed as an exchange student at Azusa's home in Japan in 2002 on a one-year student exchange. In her interview, Evelyn described having difficulty in gaining Azusa's attention in chat, and revealed that a large portion of her e-turns were specifically aimed at spiking Azusa's interest. Evelyn went to great efforts to maintain Azusa's interest in the conversation, typing her messages in English, even though she wanted to practice her Japanese, because she knew that Azusa enjoyed speaking English, and attempted to use this tactic to lure her into a conversation. Whenever she felt Azusa's attention waning, Evelyn would code-switch back to English, stating in her interview "I didn't want to lose her". One of the chat logs Evelyn submitted for the study was a failed example of her attempting to entice Azusa into chat conversation, where Azusa appeared online, but did not respond to any of Evelyn's utterances. In the chat log reproduced below, Evelyn's use of English to gain Azusa's attention is evident (see Figure 7). Although she begins in Japanese, Evelyn's last-ditch effort, over a minute later, having had no response, to get Azusa to chat with her, is in English. As participants were not interviewed on this early chat, it is impossible to tell whether Azusa was knowingly logged in to MSN Messenger and ignored Evelyn, or did not realise Evelyn was trying to attract her attention. However, Evelyn did refer to this failed attempt in the interview, and stated that it was her reason for utilising the strategy of starting the next conversation in English. Evelyn and Azusa also did not engage in the teacher-learner role swapping and reciprocal learning that language exchange partners Kaylene and Ruriko did. Evelyn described in her interview how she felt that her Japanese was inadequate compared with Azusa's level of English, and revealed that she would type new words into her dictionary "rather than asking her, what does that mean, because it's just easier”. For the majority of her interaction with Azusa, Evelyn's primary goal was to maintain Azusa's cooperation in a social conversation, an inequality in interaction reflecting their unequal relationship.

\begin{tabular}{|l|l|l|l|l|}
\hline Date & Time & From & To & Message \\
\hline $9 / 05 / 2006$ & $12: 30: 54$ & Wallaby & 梓 & $\begin{array}{l}\text { 梓 } ! \\
((\text { Azusa! }))\end{array}$ \\
\hline $9 / 05 / 2006$ & $12: 30: 54$ & Wallaby & 梓 & $\begin{array}{l}\text { 元気? } \\
((\text { How are you? }))\end{array}$ \\
\hline $9 / 05 / 2006$ & $12: 31: 27$ & Wallaby & 梓 & hello? \\
\hline
\end{tabular}

Figure 7. Evelyn's (Wallaby) attempted conversation with Azusa.

Where one partner produced considerably more e-turns, or lengthier e-turns, than the other, a vertical power relationship was formed, whereby one partner took on the role of the reader, and the other, of the writer. The majority of the chats contained 
slightly more Japanese than English, and accordingly, the Japanese native speakers composed and sent the majority of the e-turns. The vertical relationship produced when one speaker took on or was given the identity of the 'native speaker' is evident in Jacob's waiting for Miku to finish, Evelyn's attempts to maintain Azusa's interest, and Phia's casting of herself as the 'listener', as she reported in the interview. It is important to note that it is not always the partner who produces the highest volume of text that holds the most power. Azusa wielded power in her contact with Evelyn by being non-responsive. Furthermore, Phia commented in her interview that in chats with her former classmate, Soichiro, she made efforts to "indulge him" in topics that seemed to interest him, and stated, "I was just listening to the story". Education student Nadia reported waiting ten minutes for her chat partner, Tomi, to say goodbye to her, and stated an hour later in the interview "I felt a bit sad", and "I thought it was rude" that she did not respond. Nadia later reported that she and Tomi never contacted each other again.

\section{Multitasking and Ignoring}

In addition to the personal relationships between the interlocutors, a number of other technological and sociocultural factors influenced participant's levels of participation. While using online chat in this study, all except one of the participants were multitasking - completing between two and four activities simultaneously. On the computer, these activities included writing, chatting with others in separate chat windows, writing emails to other friends, consulting an online dictionary for assistance in the conversation at hand, surfing the web (for assistance in the conversation or for leisure), playing games, listening to music, and even using PowerPoint for work, or Word for study. Real world concerns also interrupted participant's online activity. Participants left conversations to go to the bathroom, and one participant, Jacob, carried out a face-to-face conversation in English with his father on the same topic as his online conversation with Miku in Japanese at the same time.

Participants engaged in multiple activities simultaneously were often more distracted, and hence less attentive, than the participants who were concentrating solely on the conversation at hand. In the case of the education students, Tomi explained that she was writing an email to a friend, as well as chatting to someone besides Nadia in a separate window. When Nadia said goodbye, Tomi simply concentrated on her second chat window, while Nadia waited for ten minutes, staring at the screen, for Tomi to say a formal goodbye. Chatting with multiple interlocutors also influenced language choice, as many users had difficulty switching between the Japanese and English orthography input methods, using either the keyboard or mouse. Phia described great frustration about not knowing the keyboard shortcuts to switch between Japanese and English, 
and commented that if she started in one language, she tried to use that language for as long as possible, so that the conversation would not be interrupted by her cumbersome orthographic switching method. So although she was highly motivated to practice her Japanese, and was one of only two participants who identified language learning as a goal, Phia used primarily English in her conversations with Soichiro if she was simultaneously chatting with an English speaker in another window. In turn, this then meant that Phia was the 'native speaker' in their primarily English conversation, and Soichiro shouldered the bulk of the labour in terms of decoding Phia's turns.

Other learners found that engaging in multiple activities at once was actually beneficial to their conversation and their language learning. More than half of the ten participants reported using either online or electronic dictionaries while chatting to assist their conversation and language acquisition, and one Australian student even completed her homework while chatting with her Japanese chat partner. Those students who did not use dictionaries often had extenuating circumstances (such as Miku, the social chatter who had lent her dictionary to a friend). The two main types of reference sources used were electronic dictionaries (5/10 participants) and online dictionaries (3/10 participants). Electronic dictionaries are small hand-held computers, similar in size to a calculator, which contain integrated reference materials, often including a Japanese monolingual, Japanese-English, English-Japanese, and an in-depth kanji dictionary. Online dictionaries are usually free to use, searchable dictionaries accessible via the Internet. Two of the participants, Nadia and Kaylene, used multiple sources, a combination of electronic and online dictionaries.

Online dictionaries were found to have several advantages over electronic dictionaries, firstly, in confirming the readings of kanji. Nadia revealed in her interview that she used the dictionary web site Rikai after her failed attempt to use her friend's electronic dictionary, to look up the readings of kanji sent by her chat partner and fellow education student, Tomi. Nadia looked up 遠い (far) and spent two minutes looking up 職業 (occupation) simply to confirm that her own readings of the pronunciation were correct, which they were. While checking the pronunciation was not directly relevant to the conversation, it was relevant to Nadia's primary goal of language learning. However, Nadia did not check her understanding of the meaning of 遠い, which was incorrect, at least at the time of interview. Nadia believed the meaning was 'close', rather than 'far'. While this appears to be a missed opportunity for learning, it did not impair her ability to answer the question「そこは遠いんですか？？」 (Is that far??) as she answered in terms of type of transportation required and time needed, rather than a binary yes / no answer, which may have resulted in miscommunication. Kaylene, on the other 
hand, only used the online Jim Breen's dictionary ${ }^{25}$ to discover the readings of kanji she did not know, such as 憧れ (yearned for) and 鶴 (crane). Jacob, too, kept Jim Breen's dictionary open throughout his chat with Miku, "just in case" but decided not to use it for time reasons, commenting that as his chat partner seemed keen he "didn't want to cause a lull in the conversation".

It appears that activities such as consulting a dictionary or surfing the web may contribute to the flow of the conversation and provide opportunities for language learning, while disruptive activities like chatting with someone else or concentrating on an email may interrupt the flow of conversation, and cause one's interlocutor to feel neglected. However, as Jacob noted, even consulting a dictionary can cause a lull in the conversation, while one partner waits for the other to look up a word. In these cases, pairs such as the language exchange partners Kaylene and Ruriko often found it beneficial to ask their partner the meaning of a word rather than using a dictionary, while Jacob preferred changing the topic altogether. Jacob often avoided topics that showed signs of developing communication difficulty. When Jacob confused the name of his chat partner Miku's home town, rather than repair, he commented in the interview that he decided to "get out of there" by changing the topic to the weather. In another situation, Jacob said that he was not sure whether Miku thought that he had quit the band or that the band had stopped, after he sent 「バンド止めました」 (stopped band). Although Jacob was unaware as to the source of the misunderstanding he perceived, he stated in the interview "my reaction, again, was get out of there! Something's not going right in the conversation, change topic". Jacob stated he was afraid that "if we'd kept talking about it, that it would have popped up again", and this formed his reason for avoiding the topic altogether, and instead complimenting Miku on her display picture.

In many cases, interviews revealed that participants were unsatisfied with the help provided by their electronic dictionaries for two main reasons. Firstly, the usage of electronic dictionaries varies considerably from model to model. Nadia, the education student, used a friend's electronic dictionary, which was unfamiliar to her, and she reported that it "didn't work", instead, opting to use an online dictionary for the remainder of her conversation with Tomi. Secondly, electronic dictionaries often contain formal language, with little or no explanation of use. This can cause two kinds of problems, firstly, when looking up slang terms. Ruriko also tried using an electronic dictionary, to look up 'hardcore', however, the meaning that the electronic dictionary gave,がんこな (stubborn) did not fit with her language exchange partner Kaylene’s slang usage of the term (dedicated). Instead, Ruriko relied upon Kaylene's explanation. Secondly, electronic dictionaries can often suggest overly formal language that does

25 http://www.csse.monash.edu.au/ jwb/cgi-bin/wwwjdic.cgi?1C. 
not fit with the sociocultural context of an informal chat. Soichiro, while chatting with his former classmate, Phia, used his electronic dictionary to look up 鎖骨(clavicle), yet after Soichiro's repeated use of the word 'clavicle', Phia said it amused her because "that's a word I probably wouldn't know, until I broke it!". She noted that "Where he uses clavicle, instead, we would use collarbone, that's, I guess, something that you wouldn't find in a dictionary, clavicle you would". This is not to say that electronic dictionaries do not have their advantages also. Kaylene stated that she used her electronic dictionary a lot, and that while chatting, she used it to look up the spelling of Japanese words, such as 一緒に (together), when she forgot whether it contains a double consonant sound (isshoni) or not (ishoni). Evelyn relied upon her electronic dictionary rather than asking her chat partner and former host sister Azusa, because it was "easier".

Overall, completing more than one task simultaneously was common among the participants, and only Nadia, the least experienced chatter, did not engage in multitasking. While participants showed high levels of skill in managing multiple conversations, and even multiple streams of conversation within several of their dyadic conversation windows at once, sometimes their partners reported feeling ignored or unheard. In a fast-paced chat, messages may scroll off-screen quite rapidly, and there is a danger that some messages may disappear unread. Furthermore, a student who stops to consult their dictionary may find that they have missed a large portion of the conversation by the time they discover the word they were originally searching for. In most cases, participants may have benefited from asking their chat partner the meaning of a word rather than looking it up in the dictionary, both to save time, and because the informal nature of chat means that many of the words that are unfamiliar to students are not included in the dictionary, or are included in a more formal sense. However, in order for participants to feel comfortable asking one another questions, they need to have first established a good relationship. Evelyn, who had a lengthy but troubled relationship with her partner Azusa, and Jacob, who had only recently met Miku online, reported that they did not feel comfortable in asking their partners questions. In particular, Evelyn not only felt that her Japanese was inferior to Azusa's English, but that she was indebted to her former host sister, and hence did not want to bother Azusa with too many questions about Japanese.

\section{Conclusions}

The research described in this paper provides insight into learners' participation in CMC with native speakers outside the classroom or computer laboratory. It was found that although participants may in theory have the same opportunities to participate, their actual participation is highly dependent upon numerous social and technical factors, 
including their language level, relationship with their interlocutor, computer dexterity, typing speed, and the demand of other tasks they may be completing concurrently, among others. This suggests that outside the classroom, the benefits of chat such as increased participation and egalitarianism, which may be present in teacher or researcher-led classroom experiments, is dependent upon the way in which the participants perceive the activity of chat, their goals, and the ways in which they choose to organise their interaction, and should not be viewed as a naturally occurring feature. It also suggests that the style of turn management is directly related to the amount of turns participants produce, with those who manage multiple strands producing a higher number of turns.

Furthermore, the simple production of an utterance does not guarantee that the receiver reads or even notices the message sent. It is highly possible for participants to accidentally skip over a turn in a fast-paced chat conversation, or to consciously ignore what is being said. It was found that several pairs had unbalanced interaction, often rooted in a social problem or chat style, and in these pairs, one participant often felt unvalued and unheard, or even inferior. While it is impossible to speculate as to whether participants' online communication was more equal than their face-to-face interaction in my own study, as face-to-face data was not collected, the point made is that even if $\mathrm{CMC}$ is branded as more equal, it would be dangerous to assume that it is 'egalitarian'. So although there appears to be a general consensus in much of the literature that chat and instant messaging can provide increased opportunities to participate in interaction, more research is required to discover what factors influence some participants to take up these opportunities.

While it is evident that roles adopted and levels of participation in chat vary and are related to the goals, relationships, and perceived relative linguistic competence of participants, chat may provide valuable opportunities for second language socialisation and language learning. As language exchange partners Kaylene and Ruriko demonstrate, relatively equal levels of participation and language use, teamed with a goal of reciprocal teaching and learning can afford both participants opportunities to take on the role of reader or writer, learner or teacher. Furthermore, this kind of role swapping allows both participants opportunities to develop as language experts, both in their native language, and in their second language. Future study would be needed to evaluate the extent to which the roles adopted or distribution of turns in chat used for language practice would affect second language acquisition. 
New Voices Volume 3

\section{References}

Abrams, Z. I., 'Computer-mediated communication and group journals: expanding the repertoire of participant roles', System, 29 (2001), pp. 489-503.

Chung, Y. G., Graves, B., Wesche, M. and Barfurth, M., 'Computer-Mediated Communication in Korean-English Chat Rooms: Tandem learning in an international languages program', The Canadian Modern Language Review/La Revue canadienne des langues vivantes, 62/1 (2006), pp. 49 - 86.

Danet, B. and Herring, S. C., 'Introduction', The Multilingual Internet: Language, Culture, and Communication Online (Oxford: Oxford University Press, 2007), pp. 1 - 39.

Engeström, 'Activity Theory and Transformation', in Engeström, Y., Miettinen, R., and Punamäki, R. L. (eds.), Perspectives on Activity Theory (Cambridge: Cambridge University Press, 1999), pp. 19 - 38.

Fitze, M., 'Discourse and Participation in ESL Face-to-Face and Written Electronic Conferences', Language Learning \& Technology, 10/1 (2006), pp. 67 - 87.

Fujiike, T., 'Collaborative Interaction in EFL Web-Based Debates: How do learners develop socially constructed knowledge?', CALL-EJ Online 5:2 (2004).

Gass, S. M. and Mackey, A., Stimulated Recall Methodology in Second Language Research (Mahwah: Lawrence Erlbaum Associates, 2000).

Herring, S. C., 'Gender and Democracy in Computer-Mediated Communication' The Electronic Journal of Communication / La Revue Electronique de Communication 3:2 (1993). Retrieved 7 October 2006, from http:// www.cios.org/EJCPUBLIC/003/2/00328.HTML.

Herring, S. C. (ed.), Computer-Mediated Communication: Linguistic, Social and Cross-Cultural Perspectives. Pragmatics and Beyond (Philadelphia: Benjamins, 1996).

Herring, S. C., 'Interactional Coherence in CMC', Proceedings of the 32nd Hawai'i International Conference on System Sciences (HICSS-32) (Hawai'i: IEEE Computer Society Press, 1999), pp. 1 - 13.

Kelm, O., 'The Use of Synchronous Computer Networks in Second Language Instruction: A Preliminary Report', Foreign Language Annals, 25/5 (1992), pp. 441 - 545.

Kern, R. G., 'Restructuring Classroom Interaction with Networked Computers: Effects on Quantity and Characteristics of Language Production', The Modern Language Journal, 79/iv (1995), pp. 457 - 76.

Kitade, K., 'L2 Learners' Discourse and SLA Theories in CMC: Collaborative interaction in Internet chat', Computer Assisted Language Learning, 13/2 (2000), pp. 143 - 66.

Kötter, M., 'Negotiation of Meaning and Codeswitching in Online Tandems', Language Learning \& Technology, 7/2 (2003), pp. $145-72$.

Neustupný, J. V., 'The Follow-Up Interview', Japanese Studies Association of Australia, 10/2 (1990), pp. 31 - 33.

Neustupný, J. V. and Miyazaki, S., Gengo kenkyū no hōhō (Techniques for Language Research) (Tōkyō: Kuroshio Shuppan, 2002).

Nunan, D., Research Methods in Language Learning (Cambridge: Cambridge University Press, 1992). 
Sacks, H., Schegloff, E. A., and Jefferson, G., 'A Simplest Systematics for the Organization of Turn-Taking for Conversation', Language, 50/4, Part 1 (1974), pp. 696 - 735.

Thorne, S. L., 'An Activity Theoretical Analysis of Foreign Language Electronic Discourse', PhD Thesis (University of California, 1999).

Toyoda, E. and Harrison, R., 'Categorization of Text Chat Communication Between Learners and Native Speakers of Japanese', Language Learning \& Technology, 6/1 (2002), pp. 82 - 99.

Tudini, V., 'Using Native Speakers in Chat', Language, Learning and Technology, 7/3 (2003), pp. 141 - 63.

Vygotsky, L. S., Thought and Language (Cambridge: M.I.T. Press, 1962).

Vygotsky, L. S., Mind in Society (Cambridge: Harvard University Press, 1978).

Vygotsky, L. S., 'The Development of Higher Forms of Attention in Childhood', in Wertsch, J. V. (ed.), The Concept of Activity in Soviet Psychology (Armonk: M.E. Sharp, 1981).

Warschauer, M., 'Comparing Face-to-Face and Electronic Communication in the Second Language Classroom', CALICO Journal, 13/2 (1996), pp. 7 - 26. 


\title{
Japanese wives in Japanese-Australian intermarriages
}

\author{
Jared Denman \\ The University of Queensland
}

\begin{abstract}
The diasporic experiences of Japanese partners married to Australians and living in Australia are largely unexamined. This article is based on a study, conducted for an honours thesis, which invited four Japanese wives living in South East Queensland to describe, together with their Australian husbands, their family's interactions with Japan, its language and culture, and the local Japanese community. It was recognised that the extensive social networks these wives had established and maintained with local Japanese women from other Japanese-Australian intermarriage families were an important part of their migrant experience.
\end{abstract}

This article will firstly review the literature on contemporary JapaneseAustralian intermarriage in Australia and Japanese lifestyle migration to Australia. It will then describe and examine the involvement and motivations of the four wives in their social networks. Entry into motherhood was found to be the impetus for developing and participating in informal, autonomous networks. Additionally, regular visits to Japan were focused on engagement with existing family and friendship networks. The contemporary experience of intermarriage for these women is decidedly transnational and fundamentally different from that of the war brides, or sensō hanayome.

\section{Keywords}

Japanese women; intermarriage families; lifestyle migration; diasporic experiences; Australia

\section{Introduction}

Research into Japanese residents, migrants and families in Australia, as well as their local ethnic communities, has slowly accumulated over the last 20 years. The lives, histories, and contributions of Japanese have been examined by historical works and celebrated in various commemorative publications which have explored the relationship between 
Australia and Japan. ${ }^{1}$ These studies have also been generated as part of celebrations of Queensland's multiculturalism and diverse ethnic communities. ${ }^{2}$

An early investigation of the Japanese community in Brisbane focused on the integration of Japanese residents into Australian society. ${ }^{3}$ Fieldwork that is more recent has thrown light on the emergence of deterritorialised urban ethnic communities developing around autonomous and non-organisational social networks. ${ }^{4}$ Similar observations have been made by other studies conducted in Sydney and Melbourne. ${ }^{5}$ While sojourning corporate families have been a feature of Japanese communities in Australia from the 1960s through to the mid-1990s, their proportion has dropped considerably due to an increase in other migrant types. ${ }^{6}$ Satō refers to them as 'lifestyle migrants, 7 and Nagatomo draws upon this concept to understand Japanese migration to Australia as a form of transnational leisure. ${ }^{8}$ The diasporic experiences and identity negotiations of Japanese residents is another aspect which has been researched, albeit to a limited degree. ${ }^{9}$

There remain few gendered perspectives on the migration of Japanese to Australia. One example is Nagata's re-examination of prostitutes in the prewar Japanese diaspora ${ }^{10}$. However, while postwar migrants have been predominantly female there has been an absence of rigorous discussion about gender and its role in their migration experiences. The scope of the original study upon which this article is based was not ambitious enough to correct this. However, the work has attempted to provide a starting point for a more thorough examination of gender in Japanese migration to Australia by identifying, in particular, the role of motherhood in the development of and participation in informal, autonomous networks with other Japanese mothers of similar migrant backgrounds.

This article will firstly review the literature on contemporary JapaneseAustralian intermarriage in Australia and Japanese lifestyle migration to Australia. Next, the methodology of my original study will be outlined. Finally, the involvement and motivation of Japanese wives who have established and maintained extensive social

\footnotetext{
1 Historical works include: Ackland \& Oliver, 'Unexpected Encounters'; Jones \& Mackie, 'Relationships'; Meaney, 'Towards a New Vision'; Nagata, 'Unwanted Aliens'; Nagata, 'The Japanese in Torres Strait'; Sissons, 'Towards a New Vision'. Commemorative works include: Kinenshi Henshū Iinkai, 'Ōsutoraria no Nihonjin'; Nagatomo, 'Japan Club of Queensland Nijūshünen Kinenshi'. A combination of the two includes Nagata \& Nagatomo, 'Japanese Queenslanders'. Brändle, 'Multicultural Queensland 2001'.

Mizukami, 'The Integration of Japanese Residents into Australian Society'.

Nagatomo, 'Datsu-ryōdoka sareta Komyuniti'.

Mizukami, 'The Sojourner Community'; Shiobara, 'The Beginnings of the Multiculturalization of Japanese Immigrants to Australia'; Shiobara, 'Middle-

class Asian Immigrants and Welfare Multiculturalism'

Mizukami, 'The Sojourner Community'.

Satō, 'Farewell to Nippon'.

Nagatomo, 'Datsu-ryōdoka sareta Komyuniti'; Nagatomo, 'Globalisation, Tourism Development, and Japanese Lifestyle Migration to Australia'.

Nagata, 'Lost in Space'; Suzuki, 'Japanese supplementary schooling and identity'; Tamura, 'Michi's Memories'.

Nagata, 'Gendering Australia-Japan Relations'.
} 
networks with local Japanese from other Japanese-Australian intermarriage families in South East Queensland will be described and examined.

\section{Contemporary Japanese-Australian Intermarriage in Australia}

Researchers have used a variety of terms to refer to the marriage of people from different backgrounds, including cross-cultural marriage and interracial marriage. ${ }^{11}$ The translated form of the Japanese term kokusai kekkon, or 'international marriage', is also used. ${ }^{12}$ Each of these foregrounds one particular aspect of difference: culture, race, and nationality respectively. Penny and Khoo use intermarriage, explaining that its definition 'depends on the perceptions about what is different within the society in which the marriage takes place ${ }^{13}$ and may involve religion, birthplace, and socioeconomic status, in addition to the previous three. While considering such differences where they occur, their Australian study of migration and integration focuses on the intermarriage of individuals born and raised in Australia and their partners who were born and raised in other countries. My study followed this usage.

A typology of Japanese residents in Australia separates intermarriage couples into two generational groups. ${ }^{14}$ The first are the war brides of the 1950s who married Australian servicemen stationed in Japan during the Allied occupation after the Pacific War. The second are the contemporary marriages of mainly younger women in their 30s and 40s. This work is concerned with the second generational group and will not undertake a thorough comparative analysis. However, it is important to note briefly at this point that interviews with war brides have revealed that many experienced loneliness and alienation, with little opportunity to associate with other Japanese, speak Japanese or obtain Japanese foodstuffs. With many coming to regard Australia as their home and choosing to become citizens, yet still proudly maintaining their ethnic origins, Nagata describes them as having a hyphenated cultural identity: Japanese-Australians. ${ }^{15}$

It is difficult to obtain a clear picture of contemporary Japanese-Australian intermarriage through official statistics. The Australian Bureau of Statistics estimates the population of Japan-born residents for 2007 at 45,613, ${ }^{16}$ however no detailed data which may indicate how many are married to Australian citizens appears to have

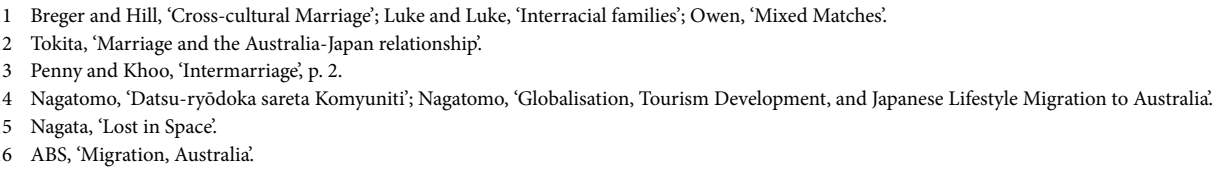


been kept. The report of the then Department of Immigration and Multicultural and Indigenous Affairs entitled 'The People of Australia', contains the most useful and recent data available. ${ }^{17}$ Using figures from the 2001 Census, it shows that 6,232 people born in Australia responded that Japan was the birthplace of one or both of their parents. Of those, 620 had an Australian mother and Japanese father, and 1,955 had a Japanese mother with an Australian father. However, these figures do not account for couples who have no children, whose children were born overseas, or how many are still dependants of their parents.

Reflected in these figures is the gender imbalance of Japanese migrants to Australia. Both Australian and Japanese government figures agree that approximately $63 \%$ of Japanese migrants are women. ${ }^{18}$ This is attributed to the migration of Japanese women who have married Australian men. ${ }^{19}$ In Mizukami's Melbourne study, ${ }^{20}$ the greatest proportion of female settlers (36.8\%) responded that their main reason for migration was 'to marry someone in Australia', with almost half of all female settlers married to an Australian. In contrast, no male respondents gave marriage as their main reason for migration. In Nagatomo's Brisbane fieldwork, ${ }^{21}$ eight of the 26 permanent residents were married to Australian citizens. Though he provides no breakdown of their gender, half of these eight couples married after the Japanese partner had embarked on a working holiday to Australia. Based on his explanation of factors that account for the high number of young Japanese women engaging in overseas tourism and working holidays to Australia, it is likely that the intermarriage couples in his work also reflect the contemporary gender imbalance.

Statistical analysis of Japanese residents in Australia may reveal their diverse demographic and socioeconomic characteristics but is limited in its capacity to portray this diversity. ${ }^{22}$ In the case of Japanese-Australian intermarriage, the lack of statistical data provides no conclusive insights, though it would appear there is a tendency for the wife to be the Japanese partner. It is here that qualitative studies can make a significant contribution.

Satō's interview-based ethnographic work examines the everyday lives and value orientations of Japanese migrants to Australia. ${ }^{23}$ Based on interviews with over 200 long-term residents, she identifies their overseas residency as motivated by

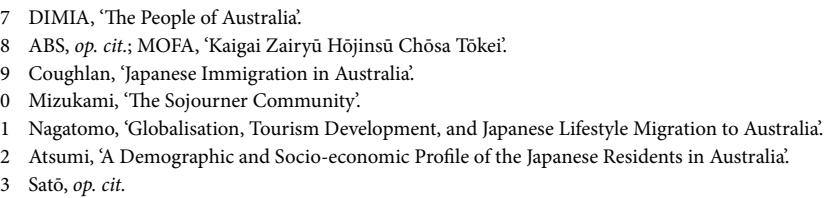


the pursuit of a better quality of life rather than a desire to escape from economic hardship. She refers to them as lifestyle migrants, a phenomenon which is discussed in the following section. In her chapter on 'the bright side and dark side of crosscultural marriage, she refers to the gender imbalance and claims that the marriages of Japanese women and Australian men are 'statistically...more likely to endure' than those of Japanese men to Australian women. ${ }^{24}$ However, her book is unreferenced and the source of this information is not given. She believes that these patterns in JapaneseAustralian intermarriage are suggestive of cultural attitudes to gender and gender roles which categorise Japanese wives in two ways: those eager to escape gender restrictions from a still largely patriarchal Japanese society, or traditional women who come for other reasons and find themselves attractive because of their old-fashioned attitudes. In her presentation of the varied experiences and reflections of her Japanese informants, including war brides, those of Japanese wives dominate. Aside from reflections on unhappy and failed relationships, other matters they spoke of included difficulties with English, longings for Japanese food and the hassle of travel to Japan. Some Japanese partners also spoke of ensuring their children grew up with a fundamental knowledge of Japanese and a positive image of Japan.

Owen's study of interracial marriage in Australia includes anecdotes from Japanese-Australian couples. ${ }^{25}$ Two couples are featured in a chapter on interracial marriage in the 1950s, and another four are studied as a part of modern marriages of the 1990s. The stories of the two war brides are generally positive accounts of being welcomed by in-laws and accepted into Australian society, unlike those of alienation and hardship which appear in more comprehensive examinations of these women's experiences. ${ }^{26}$ The contemporary group also includes couples in which the wife is Japanese. Matters of language, child bilingualism, and visits to Japan are mentioned among others, however only a small amount of space is dedicated to each couple and they are introduced with little background information.

Other works which investigate intermarriage in Australia make very few references to Japanese-Australian couples. In a paper by Luke and Luke on their threeyear study of interracial Australian families, the language maintenance activities of a Japanese mother are briefly mentioned. ${ }^{27}$ These activities include using Japanese with her son at home, having him attend supplementary schooling on Saturdays, and sending him to Japan to study for six months. Penny and Khoo's comprehensive study of intermarriage in Australia combines a statistical overview with case studies

\footnotetext{
24 Ibid., p. 127.

25 Owen, op. cit.

26 Nagata, 'Lost in Space'; Tamura, op. cit.

27 Luke and Luke, 'The Difference Language Makes'
} 
that describe the context and experiences of Australians and their partners from the United States, the Netherlands, Italy, Lebanon, Indonesia, China and Singapore. ${ }^{28}$ Japanese-Australian intermarriage is not discussed in the overview and data related to Japan-born spouses are included in only a portion of the supporting tables and graphs.

The omission of contemporary Japanese-Australian couples in discussions of intermarriage in Australia reflects the larger absence of Japan and the Japanese in works which examine Asians in Australia. ${ }^{29}$ This may be attributable to the comparatively small Japanese presence in Australia, and that the Japanese ethnic community has never established itself to the extent of other communities. ${ }^{30}$ Statistical data is unable to provide a basic characterisation of Japanese-Australian couples, though it appears certain that the wife in these unions tends to be Japanese. From the limited qualitative work that exists, matters of language, both of the Japanese partner's English ability and the transmission of Japanese to their children, and travel to Japan were touched upon by informants.

\section{Japanese Lifestyle Migration to Australia}

Understanding the phenomenon of Japanese lifestyle migration to Australia can provide insight into contemporary Japanese-Australian intermarriage. Satō uses the term lifestyle migrant in her description of long-term Japanese residents who have come to Australia since the 1970s. ${ }^{31}$ The fundamental characteristic of this migrant type is the primary importance of lifestyle factors in their decision to migrate, as opposed to the pursuit of improved economic conditions and employment opportunities. Japanese lifestyle migrants often belong to one of three broad categories: senior citizens, women, or individuals with special skills. Satō differentiates these from corporate sojourners and their families who live in comfortable circumstances with the financial backing of their company. However, like corporate sojourners who leave Japan knowing they will return once their posting is finished, lifestyle migrants also appear to have the same intention. She observes that they hesitate to commit to settlement in Australia and 'are essentially long-term sojourners who happen to be in Australia and want to enjoy the amenities and comfort that this affords for a considerable period of their life. ${ }^{32}$

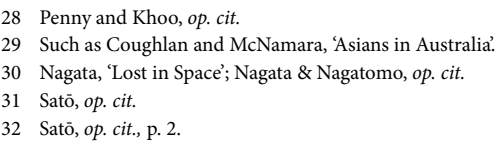


The importance of lifestyle factors for Japanese migration to Australia have been similarly referred to by other researchers, and the phenomenon of Japanese lifestyle migration has also informed recent work on Australia's Japanese communities. $^{33}$ Nagatomo further develops Satō's characterisation of lifestyle migrants, identifying three key factors: (a) They are less motivated by economic concerns than other Asian migrants; (b) many do not migrate permanently, except for those with Australian partners; and (c) they often retain Japanese citizenship, return regularly to visit Japan and maintain ties with their home community in Japan. While the first factor remains common with Satō, slight differences are apparent in the second and third factors.

In his second factor, Nagatomo allows for the likelihood that Japanese married to Australians will remain permanently. On the other hand, Sato categorises women who are married to Australian men as circumstantial migrants. Circumstantial migrants 'have come by force of circumstance' and include children born in Japan but raised and educated in Australia following their parents' migration, as well as middleaged women who accompany adult children who have migrated. ${ }^{34}$ It is difficult to reconcile circumstantial migrants within the lifestyle migration phenomena. In the case of intermarriage, marriage is understood to account for their migration and is unrelated to dissatisfaction with their quality of life in Japan. In other words, they are here because they married an Australian. However, while this may have resulted in the long-term settlement of many Japanese women in Australia, their motivations and decisions prior to this must also be considered. Previously, such women were often tourists, students, or working holidaymakers with akogare for foreign, particularly Western, experiences and lifestyles. ${ }^{35}$ Marriage may be the discrete event which draws attention, but is one part of a dynamic and ongoing migration process. Accordingly, Japanese who marry Australians and settle in Australia hold an ambiguous place within the lifestyle migration phenomenon.

In regards to the third factor, it is estimated that only one in five Japan-born residents are naturalised citizens, while the overall rate of Australian citizenship among overseas born residents is approximately 75\%. ${ }^{36}$ This tendency to retain Japanese citizenship has been discussed by a number of researchers. ${ }^{37}$ Their explanations draw upon a variety of factors including mental and psychological attachment to Japan, minimal differences between citizenship rights and permanent residency, no dual

\footnotetext{
33 The importance of lifestyle factors are acknowledged by Mizukami and Shiobara, while lifestyle migration informs the work of Nagata and Nagatomo, and Nagatomo.

34 Satō, op. cit., p. 22.

35 For a discussion of akogare see Kelsky, 'Women on the Verge'.

36 DIC, 'Community Information Summary'.

37 Atsumi, op. cit.; Mizukami, 'The Sojourner Community'; Satō, op. cit.
} 
citizenship arrangements, and practical reasons for retaining the privileges of Japanese citizenship. Satō does not mention regular return visits or the maintenance of social networks in Japan, though the former are often raised in discussions of the language and cultural maintenance activities of Japanese families in Australia. ${ }^{38}$

Japanese lifestyle migration remains undertheorised and has yet to pay explicit attention to the role of gender in migration. Nevertheless, the characteristics of Japanese lifestyle migrants to Australia outlined above provide useful starting points for this investigation of the diasporic experiences of Japanese wives in Japanese-Australian intermarriage families. It is anticipated that similar tendencies in social networks and return visits to Japan will exist.

\section{Methodology}

This study employs a qualitative research methodology, suitable for undertaking flexible research which can account for subjective realities. ${ }^{39}$ Ethical clearance to conduct the project was applied for and granted in accordance with the guidelines of the ethical review process of the University of Queensland.

Four participant couples who satisfied the following criteria were recruited for this study: (a) Married couples comprised of a Japanese wife and Australian husband who were both born and raised as citizens in their respective countries of origin; (b) parents with at least one child currently undertaking compulsory education; (c) current residents of South East Queensland. These criteria reflect the dominant pattern of gender imbalance, assumed tendency for parents of school-aged children to have made a long-term commitment to settlement in their current location, and the need to conduct face-to-face interviews with participants in a timely and cost-effective manner. Fortunately, South East Queensland is a common destination for both Japanese tourists and migrants, and the gender imbalance of this region's Japanese residents is an accurate reflection of national figures. ${ }^{40}$

Personal and professional acquaintances were approached for assistance in locating suitable couples, in a form of snowball sampling. ${ }^{41}$ Unsurprisingly, this sampling method resulted in the involvement of participant couples who knew each other through their local Japanese social networks. However, the important role

38 Suzuki, op. cit.; Yoshimitsu, 'Language maintenance of Japanese children in Morwell'.

39 Denzin and Lincoln, 'Introduction'; Flick, 'An Introduction to Qualitative Research'; Robson, 'Real world research'; Silverman, 'Interpreting Qualitative Data'.

40 ABS, op. cit.; MOFA, op. cit.

41 Robson, op. cit. 
of these networks in the wives' diasporic experiences only became apparent while conducting the interviews.

Each couple were provided an information sheet and short questionnaire in both English and Japanese. The questionnaires, based on those developed by other researchers ${ }^{42}$, solicited demographic and background information on the family. In-depth interviews ${ }^{43}$ of approximately one hour in duration were conducted with each couple in their own home and audio recorded. As I am fluent in both English and Japanese, participants were assured that they could freely express themselves in either language, though English was the main, common language used by all participants.

Wives and husbands were interviewed together to increase the number of data sources for each family. The wives' observations and opinions of themselves and their family were enriched, clarified, and sometimes challenged by their husbands. It was understood that this arrangement could limit the wives' participation, however the instances of disagreement and tension during the interviews suggest both partners felt sufficiently comfortable to express themselves and raise differences of opinion.

The technical and interpretational issues of transcription were taken into consideration. ${ }^{44}$ My transcriptions of the interviews were in full and largely verbatim, leaving grammatical mistakes such as confused word order and incorrect use of tense unedited. Analysis was conducted using an eclectic, bricolage approach commonly employed to interview data. ${ }^{45}$ Patterns and themes emerging from the data which resonated with the characterisations of Japanese-Australian intermarriage and Japanese lifestyle migration were identified and explored further.

Due to space constraints, a detailed profile of each participant couple is not included here. Instead, a summary of basic demographic information is provided in the table below. Participants' names are replaced with pseudonyms.

\footnotetext{
2 In particular Suzuki, op. cit. and Yamamoto, 'Language use in interlingual families'.

43 As outlined by Taylor and Bogdan, 'Introduction to qualitative research methods'.

44 Kvale, 'Doing Interviews'.

45 Ibid.
} 
Table 1: Participant wives and their families

\begin{tabular}{|c|c|c|c|c|}
\hline & Family A & Family K & Family S & Family T \\
\hline Wife & $\mathrm{Ai}(36)$ & Kasumi (45) & Sayuri (46) & Tomomi (47) \\
\hline Year of Marriage & 2002 & 2000 & 1992 & 1999 \\
\hline Occupation & $\begin{array}{l}\text { Part-time Call } \\
\text { Centre Operator }\end{array}$ & Homemaker & $\begin{array}{c}\text { Secretary of } \\
\text { Family's Business }\end{array}$ & Homemaker \\
\hline Visa & $\begin{array}{l}\text { Permanent } \\
\text { Resident }\end{array}$ & $\begin{array}{l}\text { Permanent } \\
\text { Resident }\end{array}$ & $\begin{array}{c}\text { Permanent } \\
\text { Resident }\end{array}$ & $\begin{array}{c}\text { Permanent } \\
\text { Resident }\end{array}$ \\
\hline Citizenship & Japanese & Japanese & Japanese & Japanese \\
\hline JCB Membership & No & No & Yes & Yes \\
\hline Japanese Groups & Mamas group & $\begin{array}{c}\text { Playgroup and } \\
\text { private kindy }\end{array}$ & $\begin{array}{l}\text { Playgroup and } \\
\text { JLSSQ }\end{array}$ & $\begin{array}{l}\text { Playgroup, } \\
\text { private kindy, } \\
\text { and JLSSQ }\end{array}$ \\
\hline Visits to Japan & $\begin{array}{c}4 \text { weeks every } \\
\text { year }\end{array}$ & $\begin{array}{c}2 \text { weeks every } \\
2-3 \text { years }\end{array}$ & $\begin{array}{c}4 \text { weeks every } \\
\text { year }\end{array}$ & $\begin{array}{c}2 \text { weeks every } \\
2-3 \text { years }\end{array}$ \\
\hline Husband & Andrew (38) & Kevin (61) & Sam (49) & $\operatorname{Tim}(47)$ \\
\hline \multirow[t]{2}{*}{ Children } & Aaron (5) & Kacie (7) & Sarah (10) & Todd (8) \\
\hline & & & Scott (7) & Teresa (5) \\
\hline
\end{tabular}

\section{Local Relationships: Networks with the Japanese Community}

The Japanese lifestyle migrant community in Australia involves social networks that are deterritorialised, autonomous, and non-organisational. ${ }^{46}$ The extensive networks and regular interactions between the four wives and local Japanese reflect this. In general, the birth and raising of children prompted them to search for and develop supportive social networks. These networks were based around informal mothers groups and semi-formal playgroups whose participants were almost exclusively other Japanese women married to Australian men with children of similar age. Although the wives

46 Nagatomo, 'Datsu-ryōdoka sareta Komyuniti'. 
explained that the purpose of attending these groups was to provide their children with an opportunity to play together and speak Japanese, their husbands pointed out that the groups also served as support groups for mothers. Here, a combination of instrumental and personal motivations is evident.

Three couples spoke of attending activities held by official Japanese organisations for local intermarriage couples in the early stages of their married life. However, they discontinued their involvement before forming any close friendships. The reasons given for this were the small size of the groups and disinterest in the type of activities. Another possible explanation may be the somewhat contrived nature of these gatherings, the common thread being participants' intermarriage instead of a shared interest or activity. This interpretation is supported by the circumstances under which the wives, as mothers, came to form close relationships with other local Japanese.

Motherhood was the catalyst for the establishment of important and lasting social networks. Kasumi's recollection on her first year in Brisbane before moving to the Brisbane Valley illustrates this point:

Kasumi: $\quad$ First ... year, I haven't seen any Japanese even if I live in [inner city Brisbane] .... I haven't seen any Japanese from October to July. And I don't know anyone, any Japanese during that time. Then I met one in Cannon Hill ... she has similar age group daughter. Then we start talking about maybe we're going to find playgroup. Then we start to search playgroup together .... Then I start meeting all the Japanese after that, after went to playgroup.

The period following her arrival appears similar to many war brides who rarely encountered other Japanese. Yet she did not express any feelings of alienation or loneliness which are characteristic of war bride experiences. ${ }^{47}$ It is interesting that a chance meeting with another Japanese mother and her child coincided with a common goal to search for a playgroup. Arguably, had they not been mothers with children of similar age then the encounter may not have continued beyond a friendly greeting. This reflects the observation that lifestyle migrants in Brisbane's local Japanese community participate deliberately and selectively in networks which fulfil particular needs at particular times, as opposed to engaging regularly and formally with established Japanese organisations ${ }^{48}$. 
Kasumi, Sayuri, and Tomomi attended the same Japanese playgroup, based at a church on Brisbane's southside, from the time their children were two. The use of such facilities reflects the deterritorialised nature of the Japanese ethnic community and the autonomous networks of local Japanese, particularly lifestyle migrants. ${ }^{49}$ In this case, a place with no enduring connection to the Japanese community is appropriated by the playgroup and transformed into an exclusive Japanese space for a couple of hours each week. Sayuri's husband provided an interesting overview of the playgroup and its role in their family:

Sam: $\quad$ All the mums with the bubs ... getting together on a Friday. I used to call it the 'Playgroup Mafia' or the 'Playgroup Yakuza', and that's probably Sayuri's biggest support network. And that's probably where all our Japanese friends stem from .... So all the other mums in our social network all had kids around the same age and they would all meet on a Friday, and they'd all drink tea and complain about husbands. The kids all play and they would get together to go to a dinner and all the dads would get together and we've just been good friends ever since. The families go away together. We go camping together. All the kids went to the same Japanese primary school .... It's the Japanese crew; you can see them in the photo [over there]. Sarah and Scott have had those friends since from when they can remember: the Japanese Crew. And we see them twice a week. The world will come to an end if we can't have McDonald's after Japanese school with the Crew. And all the mums get together and sit and drink coffee hours on end. I don't know who likes it better: all the mums getting together or all the kids getting together.

The reasons for being involved in such playgroups are directly related to the benefits its participants derive from it. For the mothers, it is a time and place where they can comfortably associate with other Japanese women, of similar migrant and intermarriage experiences, in their first language. It is also an environment that supports the acquisition and maintenance of their children's Japanese through interaction with other similar children. Here, social networks that gather and concentrate the wives' cultural capital at an arranged time and place support the intergenerational transmission and reproduction of capital within the family ${ }^{50}$.

As the children outgrew playgroup and started kindergarten or school, some continued on to the Japanese Language Supplementary School of Queensland (JLSSQ). Those who did brought with them their existing social networks, which now appear to 
have blended with those of other students and their families who come from other parts of Brisbane. Kasumi's daughter is one who has not continued on, choosing to pursue weekend dance and drama lessons instead of studying Japanese on Saturday mornings. She no longer meets regularly with any of her 'Japanese' friends, and her separation from this social network is likely to have contributed to her sudden loss of Japanese halfway through the first grade. Unfortunately, maintaining children's language skills is a losing battle for most intermarriage families in Australia. ${ }^{51}$ Interestingly, Kasumi herself still maintains her friendships with other mothers from the playgroup and occasionally attends JLSSQ activities, such as its fundraising bazaar. This shows the important and continuing role these social networks play as personal bonds, even once initial motivations for doing so are no longer a priority.

Ai belongs to a separate group of about eight Japanese mothers who have married Australian men and bought properties in the local housing estate. Some are friends she has known from her time as a single working holidaymaker on the north side of Brisbane. These wives do 'mama nights, let the kids play together and barbecues' and their husbands are also 'forming links.' While this sounds quite similar to Sam's overview of the playgroup above, Ai's husband was not so positive. Instead, he was critical that 'there is absolutely not a single Aussie girl who is involved':

Andrew: I think it causes division, without that being the purpose for what you're getting together for. Other groups outside will look at that and go, 'Why?' And it happens with most enclave type or clique type arrangements where people look at it and go, 'Why do you feel threatened by having an Australian woman in the group?' ... I know that it's to make you feel at home, but I think it's important for Aaron's development and all your children's development to have that integration, that display of an ability to cross bridges.

To Ai, the reason why Australian women were not a part of her Japanese social group was obvious: 'We talk in Japanese all the time.' She defended herself further, explaining that she chatted with the 'Australian mums' of her son's friends at school. In response to Andrew's suggestion that she could include those mothers in their mamas' group, she made it clear that the exclusivity offered by this group, beginning with its 'members' and their native language, is especially important to her:

Ai: $\quad$ Because they probably don't want to. Because it's very Japanese. Because between my friends I've never spoken English, so that's really awkward

51 Luke and Luke, 'The Difference Language Makes' 
for me to have both languages in the group. It feels uncomfortable. If so, I'd probably go into an Australian group by myself, no bringing one Aussie into Japanese group.

Being a member of official organisations, such as the Japanese Club of Brisbane (JCB), and participating in the activities these offer has not played a significant role in any of the families social networks. Families $\mathrm{S}$ and $\mathrm{T}$ are members for the sole reason that it is a condition of their children's entry into the JLSSQ. Any involvement in club activities was directly connected to the school, such as fund-raising bazaars, picnics, and culture days. This again reflects existing observations of network participation that fulfils particular needs at particular times ${ }^{52}$. When asked whether they would be members if it were not a condition of enrolment in the JLSSQ, both families were unsure. Sayuri continued:

Sayuri: If they came like a new people, maybe I might join. But I lived in Australia for a long time, so I know quite a few Japanese people, so it's not so necessary to keep in contact. And maybe if I work in Japanese company perhaps I will join.

Interestingly, though the wives in this study have established and maintained small support groups for the personal and instrumental motivations discussed above, they are keen to limit their involvement with official organisations which operate to provide similar support networks and resources. This is an example of the autonomous operation of grassroots level networks within the Japanese ethnic community. ${ }^{53}$ Kasumi, who has never been a member, explained why she avoids organisational involvement:

Kasumi: $\quad$ I think it's too much complicated, the Japanese society in Brisbane. If [it's] friends it's alright, like playgroup friends. But it becomes like society; there are lots of very Japanese way to running all the club. Like lots of groups ... even the Japanese school. They have like group and [you] have to be joined to one group, otherwise ... [your] by 'self. Then in group have boss and [deciding] who is the boss. This sort of many Japanese things.

Interviewer: And you don't like that?

Kasumi: $\quad$ No. When I was in Japan I do ... freelance work all the time. Then I don't like company style in Japan. I want to do what I want to.

52 Nagatomo, 'Datsu-ryōdoka sareta Komyuniti'. 
Dissatisfaction with facets of life in Japan and Japanese society is one reason attributed to the increase in Japanese lifestyle migrants to Australia, as well as young Japanese women embarking on working holidays. ${ }^{54}$ Yet the existence of grassroots level networks, and especially the playgroups and mamas' groups of these four wives, indicate a strong interest in remaining connected with the Japanese community. Kasumi's comments suggest that selective involvement with official organisations and a preference for autonomous networks may be attributable to a dislike of the hierarchical nature, formalities, and obligations of interpersonal relationships in Japanese society.

\section{Remote Relationships: Trips to Japan}

A characteristic of Japanese lifestyle migrants to Australia is their regular return trips to Japan. ${ }^{55}$ Such visits were common to the four families. Wives returned with their children for a period of two to four weeks over the Christmas and New Year holiday, either yearly or once every two to three years. Husbands did accompany them on such visits, though usually only half as often and for a shorter length of time. Work commitments were cited as keeping them from going and staying longer, though economic considerations appeared to play a factor as well.

The main reason for the wives' regular trips to Japan was to see family and friends. Grandparents, in particular, were keen to see their young grandchildren, and in one case have been contributing financially to ensure they visit. Ai recalled that after the birth of her son she felt the need to be closer to her parents and has returned with Aaron every year. The ailing health of elderly parents among other wives provoked a sense of urgency; Tomomi spoke of wanting to see her mother 'as much as I can because I don't want to regret it later.' This is an example of 'the burden of guilt and regret of separation' commonly experienced by intermarriage couples. ${ }^{56}$

Other common reasons for their visits were based upon what they did not have access to and missed as a part of everyday life in Australia. The affordability and convenience of modern air travel allows for return visits to bond with the homeland, as well as stock up on tangible, consumable aspects of home. This is quite different to the experiences of war brides, many of who only returned to Japan several decades after migrating and relied on local contacts and sailors for limited access to items from home. ${ }^{57}$

\footnotetext{
54 Mizukami, 'The Sojourner Community'; Nagatomo, 'Globalisation, Tourism Development, and Japanese Lifestyle Migration to Australia'.

55 Nagatomo, 'Datsu-ryōdoka sareta Komyuniti'.

56 Penny and Khoo, op. cit., p. 208.

57 Nagata, 'Lost in Space.'
} 
Tomomi enjoys reading and buys up on second hand books when she returns. In addition to forms of entertainment, 'real' Japanese food was another thing spoken of fondly. Intangibles were also important. For Ai, not knowing 'what they think about, currently talk about' was what she missed when away from Japan. Sayuri also spoke of loss:

Sayuri: $\quad$ You ... miss so many things in Australia. You miss food and you miss smell. People never understand when they don't go overseas, they don't know what this feeling is. It's like something lost or something empty or something.

Accordingly, for the wives in this study a return visit is not considered a holiday. This was raised at the end of one interview, and clearly illustrates the ongoing presence of the homeland in their diasporic experiences:

Sam: I say we go overseas every year for a holiday, and Sayuri says 'It is not a holiday; we are going home to see my family. A holiday is going to France or Italy or the north and south coast. This is home.'

Two families divided their time in Japan between seeing family and friends, and travelling within the country. Travel involved activities they would not normally do in Brisbane, such as skiing. Travel was a way to introduce husbands and children to Japan and its culture. Kasumi explained her family would plan new trips each time to show Kevin and Kacie different parts of the country. Kasumi's mother would also join them and introduce aspects of traditional Japanese culture in her beloved Kyoto.

Families $A$ and $S$ spoke of how beneficial the yearly trips were to the maintenance and development of their children's Japanese. Living in the wives' parental homes and meeting with extended family provided a near exclusive Japanese language environment, particularly when fathers were absent. Just as their social networks do in Australia, these visits assist in the intergenerational transmission and reproduction of the wives' cultural capital. Sayuri's children attend the local elementary school for three weeks leading up to the New Years break. This provided the children with 'a different experience', particularly beneficial to language learning:

Sam: $\quad$ They've got little friends, a little circle of friends there they just click back into every year. And just to get the songs, the language, to learn the culture and play Pokémon. Scott is a Pokémon master with all the boys at lunchtime. But talking in Japanese about Japanese Pokémon; that's the best way to learn. 
For intermarriage couples with a migrant partner whose parents are still overseas, the maintenance of ties often requires a large commitment of the couple's assets. ${ }^{58}$ Many of the families in this study were concerned about the cost of their trips to Japan. Returning had become increasingly expensive as children were born and grew older. The economic burden increased even more for wives whose hometown is outside of Japan's major cities. For Tomomi and Tim, taking the train from Tokyo to the Tohoku region means an additional $\$ 1000$ in overall transport costs. For Ai and Andrew in particular, the cost of trips was a clear source of tension. She considered it reasonably affordable, however her husband abruptly disagreed:

Interviewer: So is it affordable?

Ai: $\quad$ These days [a discount airline] is really cheap.

Andrew: $\quad$ No.

Ai: $\quad$ But, I saved.

Andrew: Ai's parents will pay most of the time. It's very important for them to have their time with him, so they are quite prepared to pay. 'Cause I jumped up and down at one stage saying we can't afford to pay thousands of dollars once a year with what we're coming into with the mortgage and so forth. So after that I think they started to pay.

Ai: $\quad$ I could use my own credit card here, but I also have Japanese card linked to Japanese bank which has savings. When I go back to Japan, my parents probably give me some pocket money and I will just save it. They are not particularly paying it for us; I'm just spending those savings on my Japanese credit card.

This is an interesting twist on the sending of remittances and financing of grandparents' fares and extended stays in Australia by intermarriage families with an Asian partner, particularly ethnic Chinese. ${ }^{59}$ Ai plays down the economic aspects of the visits and even 'launders' the money her parents provide for these through her personal savings. Nevertheless, her husband is uncomfortable with her parents paying:

Ai: $\quad$ Oh, I don't really spend much, 'cause we stay with parents' house. 
Andrew: $\quad$ Yes I know, but ... I don't want to have your parents paying for us. I don't think that that's appropriate. And we're adults, we're earning money, we should be able to pay and plan for our own holidays.

Ai: $\quad$ Yeah, we do, we do though.

To Ai who misses home, these visits are a necessity. On the other hand, to Andrew such 'holidays' are a luxury. Nevertheless, not all the wives feel this way. Kasumi's feelings towards Japan are different to those expressed above by Sayuri and Ai:

Kasumi: I don't mind going there, but maybe two weeks is enough for me. One week for catching up all the friends .... Then second week, maybe we just go somewhere in the country. So we'll be travelling. But just two weeks is enough I think for me. I want to go home. I'm missing here.

Similarly, not all families referred to the trips as a way of providing their children with an opportunity to develop their Japanese language skills. Tomomi and Tim spoke of their misgivings about the competitive Japanese education system. Tim was also hesitant to place his children in the local schools during trips like Family $\mathrm{S}$ did, believing that 'trying to fit into a new class' was a 'disruption' that 'must depend a lot on personalities.' His wife also alluded to other Japanese-Australian intermarriage families whose children had disliked the experience and refused to go.

\section{Conclusion}

The entry of these four Japanese wives into motherhood was found to be their impetus for forming important social networks with other local Japanese. These networks were based around informal and semi-formal playgroups whose participants were predominantly other Japanese women with children of similar age and married to Australian men. For the mothers, these groups provided a time and place to bond in their native language with other Japanese women of similar experiences. It also facilitated the transmission and reproduction of cultural capital, in particular the Japanese language, to their children. As children grew older and moved on to supplementary schooling or chose to engage in other activities, these networks continued to play an important role in the wives' social lives. While enrolment in the JLSSQ required JCB membership, their associations with local Japanese were still based primarily upon friendships and participation in autonomous networks rather than official organisations. 
Regular visits to Japan were common to all four wives and were focused on engagement with existing family and friendship networks. Though regarded as holidays by their husbands, for the wives these trips were important opportunities to return home and gain access to experiences and items they missed from everyday life in Australia. Two of the wives divided their time between social engagements and travel, one purpose of which was to introduce husbands and children to Japan and its culture. An important benefit of staying with Japanese relatives and attending local schools for those couples actively fostering their children's bilingualism was the exposure of their children to an almost exclusively Japanese language environment. The economic burden of yearly travel was a noticeable source of tension in one interview and shows how travel to the migrant partner's country may be perceived differently within an intermarried couple. In this case, a wife's necessity to return 'home' is in conflict with her husband's feeling that such 'holidays' are a luxury.

This study did not attempt a comparative analysis of different intermarriage cohorts, however it is clear that the diasporic experiences of the contemporary generation of Japanese women are fundamentally different from those of the war brides. Unlike the latter who often concealed their Japaneseness in an attempt to assimilate into a post-war White Australia, the former now retain and maintain their Japanese identity, utilising it to develop supportive networks, in a multicultural Australia. As a result of increasing globalisation and advances in technology, they have not faced the isolation and alienation from country, language, family, friends, news, food, and entertainment that those who came during the 1950s endured. The contemporary experience of intermarriage for these women and their families is decidedly transnational.

The small scale of this study and its limited focus present a variety of opportunities for further inquiries into the diasporic experiences of Japanese women in JapaneseAustralian intermarriage families. In particular, the socioeconomic circumstances and employment of participants could be considered to determine how social networks may be affected by mothers' need to work and reduced capacity to socialise. Comparative work with intermarriage families settled in Japan or Japanese families in Australia may reveal different patterns in social networks or engagement with educational institutions. Additionally, research into Japanese women who have separated from their Australian partners would add further dimensions to the understanding of migration as a dynamic and ongoing process. 


\section{References}

ABS, Migration, Australia (No.3412.0) (Canberra: Australian Bureau of Statistics, 2008). Retrieved 10 September 2008, from http://www.abs.gov.au/AUSSTATS/abs@.nsf/DetailsPage/3412.02006-07?OpenDocument.

Ackland, M., and Oliver, P. (eds.), Unexpected Encounters: Neglected Histories behind the Australia-Japan Relationship (Clayton: Monash Asia Institute, 2007).

Atsumi, R., 'A Demographic and Socio-economic Profile of the Japanese Residents in Australia', in Coughlan, J. E. (ed.), The Diverse Asians: A Profile of Six Asian Communities in Australia (Brisbane: Griffith University, 1992), pp. $11-31$.

Bourdieu, P., 'On the Family as a Realised Category', Theory, Culture \& Society, vol. 13, no. 3 (1996), pp. 19-26.

Brändle, M. (ed.), Multicultural Queensland 2001: 100 Years, 100 Communities, a Century of Contributions (Brisbane: Multicultural Affairs Queensland, 2001).

Breger, R., and Hill, R. (eds.), Cross-cultural Marriage: Identity and Choice (Oxford: Berg, 1998).

Coughlan, J. E., Japanese Immigration in Australia: A Socio-demographic Profile of the Japan-born Communities from the 1996 Census. Paper presented in December 1999 at the Japanese Studies Association of Australia Conference.

Coughlan, J. E., and McNamara, D. J., Asians in Australia: Patterns of Migration and Settlement (South Melbourne: Macmillan Education Australia, 1997).

Denzin, N. K., and Lincoln, Y. S., 'Introduction: The Discipline and Practice of Qualitative Research', in Denzin, N. K., and Lincoln, Y. S. (eds.), The SAGE Handbook of Qualitative Research (Thousand Oaks: Sage, 2005), pp. 1-32.

DIAC, Community Information Summary: Japan-born (Canberra: Department of Immigration and Citizenship). Retrieved 10 September 2008, from http://www.immi.gov.au/media/publications /statistics/comm-summ/ index.htm.

DIMIA, The People of Australia (Canberra: Department of Immigration and Multicultural and Indigenous Affairs, 2003).

Flick, U., An Introduction to Qualitative Research (London: Sage, 2006).

Jones, P., and Mackie, V. (eds.), Relationships: Japan and Australia 1870s-1950s (Melbourne: University of Melbourne, 2001).

Kelsky, K., Women on the Verge: Japanese Women, Western Dreams (Durham: Duke University Press, 2001).

Kinenshi Henshū Iinkai, Ōsutoraria no Nihonjin: Isseiki wo koeru Nihonjin no Ashiato (Asquith: Zengō Nihon Kurabu, 1998).

Kvale, S., 'Doing Interviews', in Flick, U. (ed.), The SAGE Qualitative Research Kit (London: Sage, 2007), vol. 2.

Luke, A., and Luke, C., 'The Difference Language Makes: The Discourses on Language of Inter-ethnic Asian/Australian Families', in Ang, I. (ed.), Alter/Asians: Asian-Australian Identities in Art, Media and Popular Culture (Annandale: Pluto Press, 2000), pp. 42-67.

Luke, C., and Luke, A., 'Interracial Families: Difference within Difference', Ethnic and Racial Studies, vol. 21, no. 4 (1998), pp. 728-754. 
New Voices Volume 3

Meaney, N. K., Towards a New Vision: Australia and Japan through 100 Years (East Roseville: Kangaroo Press, 1999).

Mizukami, T., The Integration of Japanese Residents into Australian Society: Immigrants and Sojourners in Brisbane (Clayton: Monash University, 1993).

Mizukami, T., The Sojourner Community: Japanese Migration and Residency in Australia (Leiden: Brill, 2007).

MOFA, Kaigai Zairyū Hōjinsū Chōsa Tōkei (Tokyo: Ministry of Foreign Affairs of Japan, 2006).

Nagata, Y., Unwanted Aliens: Japanese Internment in Australia (St Lucia: University of Queensland Press, 1996).

Nagata, Y., 'Lost in Space: Ethnicity and Identity of Japanese-Australians 1945-1960s', in Jones, P. and Oliver, P. (eds.), Changing histories: Australia and Japan (Clayton: Monash Asia Institute, 2001), pp. 85-99.

Nagata, Y., 'Gendering Australia-Japan Relations: Prostitutes and the Japanese Diaspora in Australia', Ritsumeikan Journal of Asia Pacific Studies, vol. 11 (2003), pp. 57-70.

Nagata, Y., 'The Japanese in Torres Strait', in Shnukal, A., Ramsay, G., and Nagata, Y. (eds.), Navigating Boundaries: The Asian Diaspora in Torres Strait (Canberra: Pandanus Books, 2004), pp. 138-159.

Nagata, Y., and Nagatomo, J., Japanese Queenslanders: A History. (Brisbane: Bookpal, 2007).

Nagatomo, J. (ed.), Japan Club of Queensland Nijūshūnen Kinenshi: Ijū no Katari (Brisbane: Japan Club of Queensland, 2007).

Nagatomo, J., 'Datsu-ryōdoka sareta Komyuniti', in Ōtani, H. (ed.), Bunka no Gurōkarizēshon wo yomitoku (Fukuoka: Genshobō, 2008), pp. 185-204.

Nagatomo, J., 'Globalisation, Tourism Development, and Japanese Lifestyle Migration to Australia', in Nault, D. M. (ed.), Development in Asia: Interdisciplinary, Post-neoliberal, and Transnational Perspectives, (Parkland: Brown Walker Press, 2008), pp. 215-236.

Owen, J. D., Mixed Matches: Interracial Marriage in Australia (Sydney: University of New South Wales, 2002).

Penny, J., and Khoo, S., Intermarriage: A Study of Migration and Integration. (Canberra: Bureau of Immigration, Multicultural and Population Research, 1996).

Robson, C., Real world research: A resource for social scientists and practitioner-researchers (Oxford: Blackwell, 2002).

Satō, M., Farewell to Nippon: Japanese Lifestyle Migrants in Australia (Melbourne: Trans Pacific Press, 2001).

Shiobara, Y., 'The Beginnings of the Multiculturalization of Japanese Immigrants to Australia: Japanese Community Organisations and the Policy Interface', Japanese Studies, vol. 24, no. 2 (2004), pp. 247-261.

Shiobara, Y., 'Middle-class Asian Immigrants and Welfare Multiculturalism: A Case Study of a Japanese Community Organisation in Sydney', Asian Studies Review, vol. 29 (2005), pp. 395-414.

Silverman, D., Interpreting Qualitative Data: Methods for Analysing Talk, Text and Interaction (London: Sage, 2001).

Sissons, D. C. S., Towards a New Vision: A Symposium on Australian and Japanese Relations (Sydney: Japan Cultural Centre, 1998).

Suzuki, A., Japanese Supplementary Schooling and Identity: Second-generation Japanese Students in Queensland, Unpublished thesis (University of Queensland: 2005). 
Tamura, K., Michi's Memories: The Story of a Japanese War Bride (Canberra: Australian National University, 2001).

Taylor, S. J., and Bogdan, R., Introduction to Qualitative Research Methods: A Guidebook and Resource (New York: Wiley, 1998).

Tokita, A., Marriage and the Australia-Japan Relationship. Paper presented on 17 August 2007 at the 20th International Conference of the Japan Studies Association of Canada. Abstract retrieved 18 May 2008, from http://udo.arts. yorku.ca/jsac/jsac2007/.

Yamamoto, M., Language use in Interlingual Families: A Japanese-English Sociolinguistic Study (Clevedon: Multilingual Matters, 2001).

Yoshimitsu, K., 'Language Maintenance of Japanese Children in Morwell', in Marriott, H. and Low, M. (eds.), Language and Cultural Contact with Japan (Melbourne: Monash Asia Institute, 1996), pp. 138-155. 


\title{
Thinking outside the Chinese Box: David Mitchell and Murakami Haruki's subversion of stereotypes about Japan
}

\author{
Chikako Nihei \\ University of Sydney
}

\begin{abstract}
Japan has often been portrayed by orientalist stereotypes, as famously framed by Edward Said, that were mainly constituted within Europe and North America. There are two distinct streams of orientalist discourse around Japan: traditional Orientalism and techno-Orientalism. Here the West speaks of the Other/the non-West rather than allowing it to speak for itself. In regards to the discourse of 'Otherness', another interesting phenomenon is Japan's self-Orientalising: through the internalisation of the Western Orientalist discourse, Japan identifies itself and constructs its own subjectivity.
\end{abstract}

In his literary works, the author David Mitchell attempts to subvert the conventional orientalist approach to describe Japan while concurrently maintaining his position as a British observer. He makes use of Western perspectives to cater to his Western readers' preference for Japan's traditional and cultural elements, and yet at the same time attempts to subvert stereotypes. Mitchell's approach is reminiscent of Japanese author Murakami Haruki's use of both 'Japaneseness' and 'un-Japaneseness' in his works. Mitchell also learnt the importance of the use of the subjective narrative voice from Murakami. In this article, I examine how David Mitchell, as a western author, attempts to go beyond orientalist stereotypes, and how his writing is influenced by Murakami Haruki.

\section{Keywords}

David Mitchell, Murakami Haruki, Orientalism, stereotypes, subjectivity

\section{The Orientalisation of Japan}

There have been a great number of non-Japanese authors and scholars who have written on Japan from an outsider perspective, claiming to narrate Japan objectively. Such supposed objectivity, however, has often been informed by an Orientalist approach. Orientalism, famously framed by Edward Said, is a concept to account for the relation between the East and the West, mainly focusing on Western perspectives. Richard H. Minear points out three aspects of Said's theory of Orientalism: 'its use of 
the abstractions "Oriental" and "European," its prejudice in favour of the latter, and the relation in Orientalist thinking between past "Oriental" greatness and present "Oriental" degradation.' Minear explains that Said portrays the 'European' and the West as 'a known quantity, familiar and comfortable', 'rational, virtuous, mature, "normal," 'developed, humane, superior,' while the 'Oriental' is 'strange', 'irrational, depraved (fallen), childlike, "different," 'aberrant, undeveloped, inferior.' In other words, Orientalism projects an image of European (and, by extension, Western) superiority, contrasted with, and built upon, Eastern inferiority. While Edward Said formulated the notion of Orientalism mainly in relation to the Middle East, analysing Europe's representation of its closest non-Western other, the notion has been usefully applied to European and North American approaches to Japanese culture.

Scholars such as Basil Hall Chamberlain, George B. Sansom and Edwin O. Reischauer explained Japan within the context of a clearly defined East/West dichotomy. In his examination of the works of these three scholars, Richard Minear outlines the history of Western Orientalisation of Japan since 1880. According to Minear, Chamberlain divided the world into West and East, constantly writing about 'we' and 'they', and putting Japan in the same category as Korea and China. Similarly, from the late 1920s, George Samson emphasised the value of the West and taught Japanese culture within Asian studies courses, once again stressing a pan-Asian, Orientalist perspective. Edwin O. Reischauer, while describing Japan and other 'Oriental' countries as simply different, rather than inferior, also emphasised the importance of Western modernisation, arguing that such 'difference' should be reduced through the adoption of Western ways on the part of Japan. ${ }^{3}$

Thus Japan has often been understood within the context of traditional Orientalism, focusing on its exotic features and aestheticising its traditional culture and history. Western images of Japanese tradition clustered around two main approaches: they either emphasised Japan's feminine quality and its elegance, or stressed the inherently violent nature of its society. The combination of the two is aptly encapsulated by Ruth Benedict in the image of a Japan divided between 'the chrysanthemum and the sword' in her book by the same title. Rebecca Suter explains the West's aestheticising of Japan: '[a]dmiration for Japanese art, tradition, and beauty often conceals a mechanism of defense, an attempt to reify the ethnic Other in order to disempower it, and to project an image of backwardness against which the modernity of the West can be measured'. Such images of 'backwardness', which were reinforced through the aestheticisation of

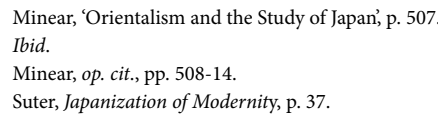


Japan's history and culture, contributed to construct an image of Japan as disempowered, while more violent images of samurai and 'warrior spirit', were used to present the country as a threat to the West.

\section{From Orientalism to Techno-Orientalism}

More recently, after Japan's successful modernisation, new stereotypes have emerged that link Japan with high-tech imagery, centring on its technological and economical success. David Morley and Kevin Robins define this phenomenon as 'techno-Orientalism, and state that ' $[t]$ he technological and futurological imagination has come to be centred here; the abstract and universalizing force of modernization has passed from Europe to America to Japan. ${ }^{5}$

In one sense, 'techno-Orientalism' is a celebration of Japan's successful modernisation. For instance, in North American science fictional works such as Neuromancer and Blade Runner, we find various high-tech images of contemporary Japan. Yoshimoto Mitsuhiro points out that '[i]n William Gibson's Neuromancer, the future world does not seem to be able to function without things Japanese.' 6 The enhancement of Japan's high-tech image is a sign of the importance of Japan's position within the representation of modernisation. To quote Iwabuchi Kōichi, 'Japan's "economic miracle"... changed western views towards Japan, because Japan has emerged as a strong competitor... As a threat to western power, the future of Japan's economic power was the main focus of concern in "the West"?

However, Japan's economic success was also perceived, and represented, as a threat to the West. According to Morley and Robins, in the 1980s the United States began to hold 'an anxiety about exposure to, and penetration by, Japanese culture', as a consequence of the global dominance of Japanese companies such as Sony and Matsushita. ${ }^{8}$ To quote Robert Reich, ' $[\mathrm{m}]$ ost American high-tech companies are well along in the process of losing their uniquely American identities' because of the Japanese 'invasion' of the American industry and of the American dependence on Japanese technology. ${ }^{9}$ American technology used to be 'viewed as something that can be uniquely American... within the nation's borders. ${ }^{10}$ However, such borders become increasingly ambiguous as Europe and the United States feel the pressure of Japan permeating their culture.

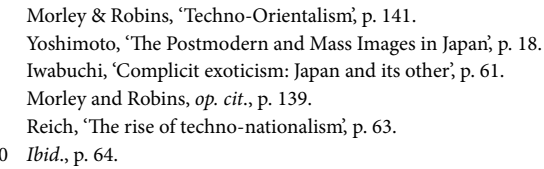


'Techno-Orientalism' constitutes a response to this perceived anxiety, and attempts to relegate Japan once again in a subaltern position by spreading an image of its people and culture as dehumanised. Stressing futuristic images such as robots and videogames makes Japanese people appear as lacking in emotion. To quote Morley and Robins:

The association of technology and Japaneseness now serves to reinforce the image of a culture that is cold, impersonal and machine-like, an authoritarian culture lacking emotional connection to the rest of the world... This recreates in a new dimension the image of the Japanese as inhuman... Within the political and cultural unconscious of the West, Japan has come to exist as the figure of empty and dehumanized technological power. ${ }^{11}$

This is reminiscent of older images of Japan as a country of violent samurai. Especially for the United States, which feels the crisis of the erosion of its borders, 'to see Japan as the enemy now is one way to bring the identity of that soul back into focus. ${ }^{12}$

\section{From Orientalism to Self-Orientalism}

Both traditional Orientalism and techno-Orientalism thus constitute attempts to differentiate Japan from Western countries in order to relegate it to a subaltern position, providing Western audiences with fixed images of Japan as backward, violent, and inhuman. In the framework of Orientalism, Western countries have treated Japan as just an object of knowledge, constantly speaking for their subaltern rather than allowing it to speak for itself. The main problem with this approach is its unidirectional dimension, the fact that this movement is almost invariably from the West to the East. Because of the easy access stereotypes offer, people tend to take them at face value without questioning their accuracy. Once people form an impression of a culture or a nation, they will believe that they have enough knowledge. Thus stereotypes limit people's knowledge by preventing them from investigating it further.

Such stereotypes however are not fixed; they also change over time, according to historical circumstances. In the specific case of Japan, Sheila Johnson thus reflects on its North American representations: ' $[w]$ hen relations are good, as at the beginning of the twentieth century or in the 1960s, aestheticized representations tend to prevail, whereas when relations become difficult, as during the war, or following the trade tensions of the 1980s, warrior Japan is the dominant image. ${ }^{13}$ While the power of stereotypes is

11 Morley and Robins, op. cit., pp. 154-5.

12 Ibid., p. 140.

13 Suter, op. cit., p. 37. 
unquestionable, such evolution and oscillation also make room for a greater degree of agency on the part of single authors, who might be able to influence the audience's perception of a culture.

As Said points out, the construction of Orientalism proceeds from the attempt to speak for the Other. Applying Said's theory to the case of Japan, Minear argues that 'the pursuit of knowledge involves the attempt to appropriate the reality of subject, and is therefore aggressive; the subject is reduced, almost by necessity, to the status of object.' ${ }^{14}$ To speak for the Other often results in ignoring its subjectivity. In a similar way, Iwabuchi explains that the Western way of picturing Japan is the expression of 'a western desire to enclose the otherness of Japan with "knowable" mysteries in order to control it'. ${ }^{15}$ To speak for the Japanese 'Other' thus enabled the West to control it.

In the post-war period, another interesting phenomenon emerged: the so-called Nihonjinron, literally 'the theory of the Japanese', a series of works variously describing and constructing the idea of 'Japanese uniqueness." ${ }^{16}$ In her study of Nihonjinron discourse, Lynn Revell explains that 'the so-called Japanese obsession with their own uniqueness exists more clearly in the eyes of the West than in Japan itself'. ${ }^{17}$ The Western stress on Japanese uniqueness in order to see Japan as the Other is reminiscent of Western Orientalist discourse and its projection of an irreducible difference. However, the discourse of Nihonjinron appropriates such rhetoric in order to construct a sense of national identity for the Japanese. To quote Revell, 'Japanese are consistently encouraged to believe not only that they are different from every other people, but that it is difference which has made Japan a great nation'. ${ }^{18}$ Through the internalisation of the Western Orientalist discourse, Japan identifies itself and constructs its own subjectivity. On one level, it would appear that through the discourse of Nihonjinron the 'subaltern' Japan can finally speak for itself, without relying on Western scholars speaking for it. However, as Revell notes, for this purpose Japanese thinkers employed intellectual tools created in the West. Insofar as Japan speaks for itself within a Western discourse, this results in a form of 'self-Orientalisation'.

In this regard, Naoki Sakai presents the mutually interdependent relationship between the West, mainly the United States, and Japan as one of fundamental complicity. While the West constructs a self-image of rationality and superiority through its relationship with Japan, Japan also defines its own position by emphasising

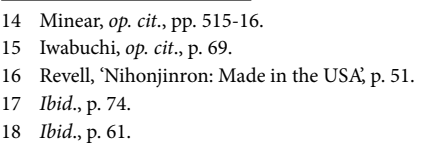


its own geographical and cultural uniqueness. Sakai states that 'Japan's uniqueness and identity are provided insofar as Japan stands out as a particular object in the field of the West... Japan becomes endowed with and aware of its "self" only when it is recognized by the West. ${ }^{19}$

The other element that is peculiar about the Japanese case is its own imperialist project in Asia, which was predicated upon a rejection of Western colonialism while at the same time incorporating some of its main features. According to Sakai, through the construction of the so-called Great East Asian Co-prosperity Sphere, Japan attempted to 'change the world so that the Japanese would occupy the position of the center and of the subject which determines other particularities in its own universal terms. ${ }^{20}$ Sakai adds that ' $[\mathrm{u}]$ niversalism and particularism endorse each other's defect in order to conceal their own; they are intimately tied to each other in their accomplice. In this respect, a particularism such as nationalism can never be a serious critique of universalism, for it is an accomplice thereof' ${ }^{21}$

From the works of Chamberlain in the early twentieth century all the way to the 1980s, such patterns of Orientalism and self-Orientalism have been the dominant mode of representations of Japan. As a complicit self-Other relationship between the West and Japan and between Japan and other Asian countries demonstrates, to speak for an Other on one's own terms often results in a pursuit of self-interest. In more recent years, however, we can also witness representations of Japan that are more nuanced and less stereotypical. I will now examine how a British author, David Mitchell attempts to go beyond these stereotypes in his novels. I also include an examination of the influence of a Japanese author, Murakami Haruki, on Mitchell's work.

\section{David Mitchell and Murakami Haruki}

Born and raised in the United Kingdom, David Mitchell moved to Japan in 1994, married a Japanese woman and lived in Hiroshima for eight years. Both his first two novels, Ghostwritten (1999) and Number9dream (2001), are set in Japan. The first novel, Ghostwritten, is constructed with ten chapters, each with a different narrative voice. The novel begins in Okinawa and moves on to Tokyo, and from there to a number of different countries. His second work, Number9dream, on the other hand, is set entirely in Tokyo, and is narrated by a Japanese nineteen-year-old boy, Eiji, from the island of Yakushima. Eiji is an illegitimate child and has never seen his father. After he loses his

19 Sakai, 'Modernity and Its Critique: The Problem of Universalism and Particularism', p. 487.

20 Ibid., p. 495.

21 Ibid., p. 487. 
twin sister, Anju, at the age of eleven, the young man travels to Tokyo to find his father, believing that this would help him find his own identity.

Making use of his experience in Japan, Mitchell in his fiction attempts to overturn the conventional Orientalist perspectives. In an interview about Ghostwritten, Mitchell explained that 'I wanted the book to travel East to West because it reverses the usual direction of Orientalism, and challenges the Eurocentric view of the world map. ${ }^{22}$ In another interview, Mitchell also states:

I have a problem with the way Japan is usually portrayed in the West, as the land of cherry blossoms, geishas, Mt. Fuji, and kamikaze pilots. I wanted to do what Haruki Murakami does, depicting Japan as it is, and finding the beauty in the ugliness. Using Japanese protagonists seems to be a more convincing way to go about that. ${ }^{23}$

Mitchell believes that having a Japanese subjective voice is a first step to go beyond conventional Western descriptions of Japan. This author's adoption of a Japanese narrative voice is quite different from the classical format in which the West speaks for the non-West in a supposedly objective perspective, as the ones I discussed in the first half of the article, in that he voluntarily adopts the perspective of the ethnic and cultural other. The author himself declares that he learnt this approach from Murakami Haruki, and in his works wants to 'depict Japan as it is'. I will come back to my interpretation of Murakami's influence on Mitchell in the next section.

Mitchell also states that his intention is 'to write a bicultural novel, where Japanese perspectives are given an equal weight to Dutch/European perspectives. ${ }^{24}$ When his interviewer mentions the variety of stereotypes about Japan that have become commonplace in the Western collective imaginary, such as 'geisha', 'salaryman', 'Nintendo', 'Aum Shinrikyo' and manga, Mitchell replies:

This plurality of lenses is no bad thing: One view is never enough...these "oven-ready perspectives" are what we fall back on, and they are probably better than nothing, provided that we don't forget that they only scratch the surface. We mustn't tell ourselves, "OK, I've got Japanese/UK/Any country culture sussed: I can stop trying to understand it now". 25

It is interesting that Mitchell calls stereotypical images 'oven-ready perspectives', foregrounding their narrow understanding of Japan. However, his intention is not

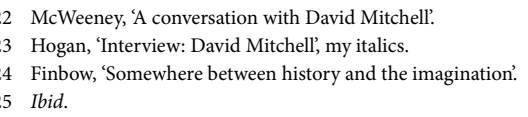


to negate the Western perspective on Japan, but to suggest the importance of having multiple perspectives from both outside and inside Japan.

Ghostwritten incorporates multiple perspectives in its very structure, as each chapter has a different protagonist/narrator. Mitchell locates his characters in different places and looks at each place subjectively, thus taking multiple subjectivities. Such combination of multiple narratives and attempts to challenge cultural stereotypes is another element that Mitchell shares with Murakami Haruki.

\section{Murakami Haruki's influence on David Mitchell (1): 'Japaneseness' and 'un-Japaneseness'}

Murakami Haruki's influence on David Mitchell has been noted by many of his readers, and Mitchell himself has discussed his admiration for Murakami's works in a number of interviews, including this one: 'I had a crush on The Wind-Up Bird Chronicle! Absolutely besotted by it. Love it, love it, love it. ${ }^{26}$ More significantly, Mitchell declares to have learnt important lessons from Murakami, stating that 'Haruki Murakami's novels show how literature can marry popular culture to cook up humour and metaphor. ${ }^{27}$ His own works are replete with references to Murakami's works. For example, the title of his book, Number9dream, which refers to a John Lennon song, \#9Dream, is reminiscent of Murakami's bestseller novel, Norwegian Wood, and its own Beatles reference. The connection is made even stronger when in the novel the protagonist Eiji, who is a big fan of John Lennon, meets Lennon himself in his daydream, and Lennon tells him that “\#9Dream" is a son of "Norwegian Wood". 28

Another element that Number9dream derives from Murakami is its description of a Japan where Western culture has become widespread. Murakami's characters often have a sandwich with coffee for breakfast, cook spaghetti for lunch and drink beer for dinner. Similarly, Mitchell highlights the blend of Western culture and Japanese traditional culture in contemporary Japan. In Number9dream, Eiji drinks a coffee in a café and green tea in his house, smokes American cigarettes, plays soccer, listens to John Lennon, and stays in the futuristic urban city Tokyo. After finishing working at a pizza shop he has his breakfast at McDonald's with a Japanese girl who plays European tunes on the piano. His father sells off a sword that was left as a family heirloom by a kamikaze pilot in his family. In a café, an old man is caught up in a videogame, and in a university a postgraduate student is busy engineering

26 Bradford, 'An interview with David Mitchell'.

27 Mitchell, 'Japan and my Writing.'

28 Mitchell, Number9dream, p. 379. 
computer viruses. A video shop plays 'Titanic' and 'Blade Runner', while yakuza eat sushi, drink sake and enjoy karaoke.

Such lack of 'Japaneseness' has long been a defining feature of Murakami's description of Japan. Elizabeth Devereaux notes that when reading Murakami's novels we should '[f] orget about cherry blossom time, the crags of Fujiyama, tea ceremonies; most especially forget about exquisitely penned haiku.' ${ }^{29}$ However, as Devereaux appreciates the presence of Japanese food in Murakami's novels as a 'last reminder of Japaneseness', Murakami's stories are also exoticised to a degree by his English-speaking audience, and are appreciated for their presentation of Japanese culture in an easily digestible format. In other words, Murakami's peculiar way of using Japaneseness in his novels contributes to his popularity in the West, especially including the United States. In her analysis of the reception of James Clavell's Shogun, Sheila Johnson explains the deeply rooted popularity of traditional Japanese culture in the West. She states that 'the overwhelming impression the book conveys is... perhaps not inaccurate for the historical period being portrayed, but the Western reader is likely to transfer such samurai images directly into the present. ${ }^{30}$ Iwabuchi Kōichi also states that Western readers have long been 'fascinated with some exotic parts of Japan, and lamented the loss of "authentic" Japanese tradition in the process of modernization.' ${ }^{31}$ The inclusion of a certain degree of 'Japaneseness' is therefore important to cater to Western readers' expectations.

As Rebecca Suter indicates, a factor that contributed to the popularity of Murakami's fiction in the English-speaking world is the work of his American translators. She states that thanks to the translators' 'domestication' of 'foreign elements in Murakami's fictions', the texts are '[p] erceived as not-too-Japanese and therefore nonthreatening... [and] are able to escape both the aestheticizing/ feminizing stereotypes and the warrior-like, violent images through which Japanese culture has generally been represented in America'. ${ }^{32}$ Thus this peculiar combination of Japaneseness and un-Japanesness in Murakami's novels functions to reduce a threat of foreignness for Western readers and make the works more palatable to them.

Murakami's popularity in the United States also stems from his choice of topics. According to Michael Fujimoto Keezing, American literary circles tend to appreciate white male authors' dealing with patriarchy and sexism, highlighting American political correctness and the formation of subjectivity in the multicultural society; authors nowadays are hardly published if they write about love or sexuality. Therefore, Keezing

\footnotetext{
Devereaux, 'PW Interviews Murakami Haruki'.

0 Johnson, The Japanese Through American Eyes, pp. 116-17.

1 Iwabuchi, op. cit., p. 49.

2 Suter, op. cit., p. 36.
} 
writes, Murakami Haruki, who often refers to love, is a non-white male and non-American 'Other' for the American literature circles and American readers. He adds that Murakami is obviously one of the great Japanese authors who appeal to contemporary America. ${ }^{33}$

In trying to explain Murakami Haruki’s popularity, Ōtsuka Eiji brings forward the design of his book covers. He explains that when Japanese author Yoshimoto Banana published her book, Kitchen, in the United States, an artist whose works have a similar taste with Sasaki Maki, the Japanese illustrator who often illustrates the Japanese editions of Murakami's books, designed the bill for the advertisement. However, Murakami's books published in the United States display pictures of a kabuki actor and a geisha. Otsuka therefore contends that despite Murakami's attempt to distance himself from other Japanese authors, he is perceived and represented as one of them in the context of the United States. ${ }^{34}$ Thus a certain degree of 'Japaneseness' in Murakami's works supports his popularity.

\section{Donuts and samurai}

The way Murakami treats Western culture in his fiction is also worthy of consideration. His use of Western elements functions to subvert conventional approaches to Japan: a particularly interesting aspect is Murakami's frequent use of katakana words. In this regard, Numano Mitsuyoshi's analysis of a scene from Kaze no uta o kike (Hear the Wind Sing, 1979) is useful:

The young protagonist is offered orange juice [orenji jūsu] and doughnuts [dōnatsu], and katakana [the Japanese syllabary for foreign words] highlights the fact that these are originally foreign products... Of course these things are common in contemporary Japan, yet to have the protagonist eat exclusively this kind of food is not a neutral choice. Furthermore, perhaps nobody does this anymore today, but until a while ago a guest was always offered green tea and wagashi [Japanese sweets]: Murakami voluntarily subverts this pattern. Even later in his life, the protagonist always eats "peanuts, fried potatoes, beer, whisky, wine, cheese, crackers." Even though these things are widespread in Japan today, to put them in a novel takes on a precise meaning. ${ }^{35}$

Suter states that 'Numano Mitsuyoshi rightly notes that the great number of katakana words in Murakami's stories has an anti-realistic effect, making the reader aware of the presence of such words as foreign, alien elements and contributing to the

\footnotetext{
Keezing, 'What Makes Him So Good?: An American Writer's Perspective on Haruki Murakami', pp. 73-4.

4 Ōtsuka, Haruki ron-sabu karuchā to rinri, pp. 3-9.

35 Numano, 'Dōnatsu, Bīru, supagetti- Murakami Haruki to Nihon o meguru sanshö', p. 150, cited in Suter, The Japanization of Modernity, p. 40.
} 
general sense of estrangement created by the texts. ${ }^{36}$ In addition to Murakami's repeated use of katakana words, Suter also points out that the 'anti-realistic effect' of Murakami's stories is obtained through his use of 'the non-abbreviated form of katakana words': 'that are usually contracted, such as rimōto kontorōrā (remote controller) instead of rimokon ("Nyūyōku tankō no higeki," 1983)... They thus undermine the naturalness and referentiality of language, distancing the reader both from the single word and from the text. ${ }^{\prime}{ }^{3}$ Murakami's use of katakana words, in a sense, seems to be a valid approach to portray contemporary Japan 'as it is', that is, in this case, permeated by Western culture and food. It is true that katakana words are broadly used in contemporary Japan, however, Murakami uses them with exceeding frequency and in a marked way that evokes for his readers a sense of unnaturalness in the context of Japanese. It makes readers aware of the existence of foreign words in contemporary Japan.

Similar to Murakami, David Mitchell's use of 'Japaneseness' functions to challenge stereotypes about Japan. In one sense, Mitchell seems to use Japanese traditional elements for a commercial purpose, answering to expectations of the nonJapanese readerships, in the same way as Murakami. Mitchell's use of Japanese traditional elements is quite successful in this respect, and has gained him a broad readership in English-speaking countries as well as prizes and favourable reviews.

For example, in Number9dream the main element that illustrates Japaneseness is the 'samurai spirit'. The novel contains several images of violence and war, mainly centring on stories of yakuza and on the diary of a kamikaze soldier. While this would seem to cater to Western readers' taste for violent images of Japan, it is interesting to examine how Mitchell presents contemporary yakuza in Number9dream. Throughout the novel, yakuza are portrayed as the heirs of samurai spirit in contemporary Japanese society. For example: they complain that Japan allows itself to be so greatly influenced by foreign countries that it disregards its own traditional culture; they lament Japan's lack of self-esteem, noting that ' $[\mathrm{w}]$ hat we lack in Japan is the necessary megalomania' ${ }^{38}$; and they declare that only yakuza still appreciate Japan's own culture and Japan itself. When Eiji asks the yakuza leader Morino for information about his father, he wonders how much he should pay for it. Morino replies: ' $[w]$ hy is it always money, money, money with kids nowadays? Little wonder Japan is becoming this moral and spiritual graveyard'. ${ }^{39}$ Morino's final remark, 'I propose you pay with loyalty' ${ }^{40}$ reflects his intention to follow the samurai code, deploring the present obsession with money in Japan. Thus the

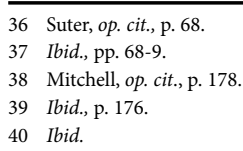


novel initially seems to portray yakuza as the repository of traditional samurai values of loyalty, selflessness, and generosity, responding to Western readers' expectations yet twisting them at the same time.

Mitchell also illustrates the wartime use of this 'samurai spirit'. In the chapter called 'Kaiten', Eiji reads a diary written by his great-uncle who participated in the program of submarine attacks called kaiten during World War Two. Kaiten was one of the kamikaze programs in which submarine pilots were ordered to crash into their target. Eiji, struggling to find his father, receives a letter from a person who calls himself Eiji's grandfather, and asks Eiji to see him in person. When they finally meet, the man gives him a diary composed by his great-uncle during his training in the kaiten program. In the diary, the kamikaze soldier tells of his longing to die for the state and the emperor as a sign of his loyalty to them. As he states that ' $[\mathrm{t}]$ he meaning of my life is to defend the Motherland, ${ }^{41}$ Number9dream illustrates the past samurai spirit in which dying for the mission guarantees a perfect fulfilment in his life.

Although both the stories of yakuza and the diary written by the kamikaze soldier seem to appreciate the samurai spirit, this is put into perspective by the highly graphic descriptions of yakuza violence. The chapter 'Reclaimed Land' describes a yakuza war in which the characters kill members of a rival gang by hitting their heads with a bowling ball. Eiji, forced to stay there, cannot turn away from the gruesome scene:

Down here is chilly and damp. I sneeze. My throat feels tight. Finally we climb to the surface on a dead escalator. "Welcome to Valhalla," says Thor, a thunderbolt in one hand and a bowling ball in the other... In the distance is a suffused glow. This is a bowling alley... Instead of tenpins are three wax human heads. The center head moves. The left head tics. I should not be here. This is a nightmarish mistake. No. This is a sort of interrogation... Lizard bows graciously and selects the heaviest bowling ball. I tell myself this is just a bluff. I should not be here. Lizard steps onto the concourse, and lines up a shot... Lizard steps one, two, and -wham! A fast, uncurving line, my gut knots, I try to wake myself up, or just look away, but when Centerhead screams I look, idiot that I am- and see the worst sight of my life, bar none. RightheadKakizaki, I guess- is no longer recognizable. I want to vomit but nothing comes. Kakizaki is a staved-in cavity of bone and blood. The horn players burst into wild applause. Lefthead is shut down with shock. Centerhead gasps, drowning, spattered with red specks. ${ }^{42}$ 
The yakuza member then forces Eiji to throw a bowling ball. Eiji is reluctant at first, but has to give in when he is told that if he refuses the yakuza will set fire to Eiji's accommodation and inflict a miscarriage upon his landlord's wife, 'I pick up a ball, the lightest. It weighs a lot. No. I cannot do this. This act is not in me... I must miss, but not obviously. I should not be here. I want to apologize to the heads, but how can I?'43

Mitchell also includes other stories about yakuza; for example, they cut the tongues of sax players, draw one litre of blood from a traitor, Daimon, and carry out trafficking of organs of innocent children. Mitchell's description of the yakuza is a far cry from the aestheticisation of samurai spirit presented in the diary of the kaiten soldier. Thus Mitchell's description of the yakuza subverts the readers' exoticising expectations: through his exaggeration of Japan's traditional images, the author provokes readers to question the use of stereotypes of Japan. Through this display of ultra-violence, Mitchell makes his readers aware of their own stereotyping of Japan. If Murakami makes use of Western elements to subvert the conventional images of Japan, Mitchell uses Japanese traditional elements to undermine the same stereotypes.

\section{Murakami Haruki's influence on David Mitchell (2): subjective voices}

Mitchell's use of a Japanese narrator is also problematic: his appropriation of the Other's narrative voice is reminiscent of a long tradition of Western authors' speaking for the non-West, implicitly situating it as subaltern and depriving it of its subjectivity. Mitchell's narrating of Japan simultaneously foregrounds and questions precisely this operation. While an underlying assumption of Orientalist discourse was the West's ability to speak about its Other objectively, Mitchell constantly stresses the importance of taking a subjective stance, something he claims to have learnt from Murakami.

In an intriguing case of flows and contra-flows of cultural influence, Murakami himself claims to have derived his own emphasis on subjective perspective from Raymond Carver, famously referred to as Murakami's favourite author. Murakami explains that Carver 'never wrote his works without using his own deeply personal words... he was a really original writer. It was only him who could describe his worlds and who could control his words. ${ }^{44}$

Murakami, then, emphasises the characters' subjectivity as a basis for their, and the text's, recognition of history. Michael Seats points out 'the dichotomy 
between personal memory and official memory' in Murakami's novels. ${ }^{45}$ Referring to Murakami's Nejimakidori Kuronikuru (The Wind-Up Bird Chronicle, 1994-95) in which Murakami describes Japan's past in Manchuria and its connection with a character's personal memory, Seats explains that this is Murakami's way of recasting history and representing reality. Especially in this case, the juxtaposition performs as the motifs of psychoanalytic and historical dissociation... [which] indicate a repression of the trauma of Japan's encounter with modernity. ${ }^{46}$ In this novel, personal memory takes a crucial role to represent official history. In other works, too, Murakami's characters often speculate on their past personal memory, which is evoked through their contact with official memory. This focus on personal rather than official memory also raised criticism of escapism. However, Murakami's intention is not to ignore history but to emphasise the influential power of personal memory on our epistemological system and the inevitability of our perceiving official memory subjectively.

In a similar way, Murakami asserts the importance of having subjectivity for readers. Jay Rubin in his analysis of Murakami's short story 'Binbō na obasan no hanashi' ('A Poor-Aunt Story', 1980), argues that '[t]he important thing for Murakami is how it feels in the mind of each of us. ${ }^{47}$ Rubin explains that, without any clear explanation by Murakami, the phrase 'poor aunt' offers readers a broad range of interpretation and imagination of 'what it means' or 'who she is'. What 'poor aunt' signifies depends on 'a sense of déjà vu' on the part of the readers, based on their familiarity and their memory. ${ }^{48}$ Murakami leaves the interpretation of his stories to the reader's individual imagination. In other words, Murakami believes that we can perceive things only subjectively, and that establishing a consensual interpretation is pointless. The insufficient information embedded in Murakami's stories allows readers to have their own way of interpretation.

Murakami's belief that subjective perspective is important is echoed in Mitchell's use of a Japanese narrative voice in Number9dream. Mitchell also emphasises the importance of relying on individual taste: ' $[\mathrm{w}]$ hich tools the writer may feel are best suited to the job may depend on the decade or the century, but also on the writer's own tastes, and "inner weather" ${ }^{49}$ Murakami and Mitchell claim that we have no choice but to narrate things subjectively. They acknowledge the invalidity of the use of stereotypes and the impossibility of narrating the Other objectively. Mitchell's attempt to write on Japan with several subjectivities can be a response to a criticism of Number9dream by Darren Waters. Waters claims that:

\footnotetext{
Seats, Murakami Haruki: the simulacrum in contemporary Japanese culture, p. 19.

6 Ibid., p. 320.

Rubin, Murakami Haruki and the Music of Words, p. 60.

8 Ibid.

49 Min, 'The Illusionist's Dream: David Mitchell chats about limb-creeping risk-taking'.
} 
The problem for Mitchell is that the land of the rising sun has become a staid shorthand metaphor for the postmodern world and number9dream finds little original or startling to say about the country or indeed the people who inhabit it... it seems dated, rooted in the 1980s; the decade of Blade Runner and when the word postmodern was fashionably hip in the halls of university campuses and the internet was a secret shared only by those in the know. ${ }^{50}$

While Waters is correct in noting that Mitchell's use of androids and his characters' obsession with video-game and computers is close to the approach of Blade Runner, Number9dream is not merely a parody of such science fiction films. Although Waters points out that Number9dream lacks originality because of its similarity with postmodern works that gained attention in the 1980s, it is my contention that Mitchell's use of plural subjectivities, including a Japanese subjectivity, as a Western author, and his attempt to subvert conventional style to describe Japan are unique approaches.

\section{Conclusion: thinking outside the Chinese Box}

While Number9dream, unlike Ghostwritten, seems to have only one subjective point of view, that of Eiji, the novel is actually constructed with several narrative voices. A number of reviews of Number9dream complain that the readers cannot distinguish among Eiji's real story, his dream/daydream/imagination, and his memory. Interestingly, Eiji's narrative voice in each of these dimensions is slightly different. Compared with Eiji in the main plot, Eiji in his dream and imagination is much bolder, to the point of showing an extremely violent personality and killing the lawyer who, Eiji believes, keeps his father's information from him. On the other hand, Eiji in his memory at age eleven has a timid personality and was often defeated in competitions with his sister. Similar to Murakami, Mitchell does not provide a clear answer as to what is actually happening, and does not clarify which Eiji is the 'real one' in the novel. In this respect, we can say that in Number9dream Mitchell also employs multiple subjectivities, by showing multiple dimensions of Eiji.

In light of this, Murakami states in the interview with Ōga that having multiple subjectivities (shiten no jūsōka) is necessary to write novels and, in this regard, the style adopted in Fyodor Dostoevsky's The Brothers Karamazov is the ideal form. ${ }^{51}$ Mitchell's use of multiple subjectivities in Ghostwritten and Number9dream is reminiscent of Dostoevsky's writing style in which he lets each character have a long speech to illustrate what happens in the novel.

50 Waters, 'Number9dream fails to rouse'.

51 Ōga, 'E-mēru intabyū: kotoba to iu hageshii buki', pp. 19-20. 
The above also reminds us of Murakami's description of reality as having a 'Chinese box-like structure' in Yakusoku sareta basho de - Andäguraundo 2 (The Place That Was Promised - Underground 2), a collection of interviews with members of the Aum Shinrikyō cult after the Tokyo sarin gas attack of 1995. In the afterword of the book, Murakami states:

I think that we see the structure of the world fundamentally as something like Chinese boxes. Inside a box there is another box, and inside that another one, and so on. I think that we unconsciously perceive the existence of another world one level outside the world we are seeing now, or one level inside it... But the people in Aum, although they say that they are desperately looking for a "different world," in fact have a very narrow vision, and see the world as exceedingly linear and simple... They are unable to see beyond one of the boxes. ${ }^{52}$

If reality is structured like a set of Chinese boxes, the implication is that we need to have multiple perspectives to examine it. To depend on a single perspective never allows people to have a broad vision. Staying inside a small box, they do not realise the presence of the outside world. Murakami adds to his statement in Yakusoku sareta basho $d e$ that 'we have to prove the box's limitation [to the members of Aum]. ${ }^{53}$ The members of Aum heavily relied on the story that the cult presented them with, and conceived it as the only truth. Cultural stereotyping is similarly limiting people's perception of reality and ignoring the multiplicity of reality.

Eleven years after publishing Yakusoku sareta basho de, Murakami returned to writing about the Aum cult in 1Q84<ichi-kew-hachi-yon>. In this novel, the author once again relies on multiple subjectivities and lets each character speak its own story in detail. In an interview, Murakami explains that in the novel he 'carefully portrayed each character, giving a name to almost all the characters, in order to arouse a sense that any character could have been ourselves. ${ }^{54}$ In another interview, Murakami also remarks, 'it is not that I wanted to write about Aum itself, but I wanted to describe the world of Aum, which has another kind of reality in it, as if it is "a box within another box" ("hako no naka no hako")'.55 His attempt to describe a Chinese-box-structured reality is therefore quite central to his role as a writer.

This gives us further insight into David Mitchell's purported aim of describing Japan 'as it is' in the same way as Murakami. In his novels, Mitchell first adopts the subjective position of the cultural and ethnic Other, writing through a Japanese narrative voice, in

\footnotetext{
Murakami, Yakusoku sareta basho de, p. 232, cited in Suter, Japanization of Modernity, p. 112.

3 Ibid., p. 233, my translation.

4 Murakami, “1Q84” e no 30 nen, Murakami Haruki shi Intabyü', my translation.

55 Murakami, 'Murakami Haruki shi: “1Q84” o kataru: Tandoku Intabyū (2) Kojin o Nijū ni Assatsu”, my translation.
} 
order to cater to Western readers' desires for Japaneseness, similar to how Murakami includes a certain degree of 'Japanese essence' for his foreign readers. However, Mitchell then proceeds to subvert the readers' expectations he has built, through his description of the ultra-violence of yakuza, while Murakami subverts them through his display of Western pop culture elements and through his use of katakana words. Such subversion of the readers' expectations ultimately leads to a subversion of their cultural stereotypes. For both authors, the principal problem with stereotypes is that they present us with a unitary and linear vision of reality, while reality is constituted, as Murakami claims, by multiple layers, like 'Chinese boxes.' Furthermore, cultural stereotypes create the impression that we can perceive, and speak for, the Other objectively, as a long tradition of Orientalist discourse testifies to. David Mitchell, on the contrary, acknowledges the fact that we can see things only subjectively, and thus chooses to write with a Japanese narrative voice in order to incorporate and deconstruct stereotypical representations of Japan. In doing this, he goes beyond both classical Orientalism and techno-Orientalism; arguably this is the most important lesson that this author learned from Murakami Haruki.

\section{References}

Benedict, R., The Chrysanthemum and the Sword (Boston: Houghton Mifflin, 1946).

Bradford, S., 'An interview with David Mitchell', The Lumiere Reader, 2 April 2008. Retrieved 6 June 2009, from http:// lumiere.net.nz/reader/arts.php/item/1611.

Devereaux, E., 'PW Interviews Murakami Haruki', Publisher's Weekly, (21 September 1991), pp. 1-12.

Iwabuchi, K., 'Complicit exoticism: Japan and its other', The Australian Journal of Media \& Culture, vol. 8, no. 2, (1994), pp. 49-82.

Finbow, S., 'Somewhere between history and the imagination', The Japan Times. Retrieved 24 June 2007, from http:// search.japantimes.co.jp/cgi-bin/fb20070624a1.html.

Hogan, R., 'Interview: David Mitchell', Indie Bound. Retrieved 28 May 2009, from http://www.indiebound.org/authorinterviews/mitchelldavid.

Johnson, S. K., The Japanese through American eyes (California: Stanford UP, 1988).

Keezing, M. F., 'What Makes Him So Good?: An American Writer's Perspective on Haruki Murakami'. Translated by Ōgushi, H., Yuriika vol. 32, no. 4 (2000), pp. 72-75.

McWeeney, C., 'A conversation with David Mitchell', Bold Type: Randomhouse. com. Retrieved 28 May 2009, from http://www.randomhouse.com/boldtype/1100/mitchell/interview.html.

Minear, R. H., 'Orientalism and the study of Japan', The Journal of Asian Studies, vol. 39, no. 3 (1980), pp. 507-517.

Min, T. H., 'The Illusionist's Dream: David Mitchell chats about limb-creeping risk-taking', Quarterly Literary Review Singapore, vol. 1, no. 2, (Jan 2002). Retrieved 28 May 2009, from http://www.qlrs.com/issues/jan2002/ interviews/dmitchell.html. 
Mitchell, D., Ghostwritten (London: Hodder and Stoughton, 1999).

Mitchell, D., 'Japan and my Writing', Bold Type: Randomhouse. com. Retrieved 28 May 2009, from http://www. randomhouse.com/boldtype/1100/mitchell/essay.html.

Mitchell, D., Number9dream (New York: Random House, 2003).

Morley, D. and Robins, K., 'Techno-Orientalism: Futures, Foreigners and Phobias', New Formations, vol. 16, (1992), pp. 136-156.

Murakami, H., “1Q84” e no 30 nen, Murakami Haruki shi Intabyū' ('30 years up to "1Q84”, Interview with Murakami Haruki’) Yomiuri Online, Yomiuri Shinbun, (16 June 2009). Retrieved 1 October 2009, from http://www. yomiuri.co.jp/book/news/20090616bk02.htm.

Murakami, H., 'Murakami Haruki shi: '1Q84' o kataru, Tandoku Intabyū (2) Kojin o Nijū ni Assatsu' ('The second interview with Murakami Haruki on “1Q84”') Mainichi jp, Mainichi Shinbun (17 September 2009). Retrieved 1 October 2009, from http://mainichi.jp/enta/book/news/20090917mog00m040002000c.html.

Murakami, H., 'Raymond Carver no hayasugita shi' ('Raymond Carver's early death') Shinchō, vol. 84, no. 4 (April 1989), pp. 244-9.

Murakami, H., Yakusoku sareta basho de - Andāguraundo 2 (Tokyo: Bungei shunjū, 1998).

Numano, M., 'Dōnatsu, Bīru, supagetti - Murakami Haruki to Nihon o meguru sanshō' ('Doughnuts, Beer, Spaghetti Three Chapters on Murakami Haruki and Japan') Yuriika (Special Issue), (June 1989), pp. 144-57.

Ōga, K., 'E-mēru intabyū: kotoba to iu hageshii buki' ('E-mail Interview: Words as Fierce Weapons') Yuriika (March 2000), pp. 8-27.

Ōtsuka, E., Haruki ron - sabu karuchā to rinri (On Murakami Haruki - subculture and ethics), (Tokyo: Wakakusa Shobō, 2006).

Reich, R., 'The rise of techno-nationalism; in the emerging debate about how to restore America's technological preeminence we are misconstruing the problem and advancing the wrong solutions', The Atlantic, (May 1987), pp. 62-70.

Revell, L., 'Nihonjinron: Made in the USA', in Hammond, P. (ed.), Cultural Difference, Media Memories: AngloAmerican Images of Japan (London and Washington: Cassell, 1997), pp. 51-81.

Rubin, J., Haruki Murakami and the Music of Words (London: Vintage Books, 2002).

Said, E., Orientalism (London: Routledge, 1978).

Sakai, N., 'Modernity and Its Critique: The Problem of Universalism and Particularism', South Atlantic Quarterly, vol. 87, no. 3 (1988), pp. 475-504.

Seats, M., Murakami Haruki: the simulacrum in contemporary Japanese culture (Lanham, Md.: Lexington Books, c2006).

Suter, R., The Japanization of Modernity, Murakami Haruki between Japan and the United States (Cambridge: Harvard UP, 2008).

Waters, D., 'Number9dream fails to rouse', BBC News Online, 12 October 2001. Retrieved 6 June 2009, from http://news. bbc.co.uk/2/hi/entertainment/1586448.stm.

Yoshimoto, M., 'The Postmodern and Mass Images in Japan', Public Culture, vol. 1, no. 2 (1989), pp. 8-18. 


\title{
Teaching culture in the Japanese language classroom: A NSW case study
}

Caroline Mahoney

University of Sydney

\begin{abstract}
This study examines, through a qualitative case study approach, how non-nativespeaking (NNS) Japanese language teachers in New South Wales (NSW) teach culture and why. The study seeks to understand the pedagogy used to teach culture, teachers' attitudes and beliefs on teaching culture and how these attitudes and beliefs have been influenced by past experiences. This study also explores how the NSW K-10 Japanese syllabus and concepts of Intercultural Language Learning (IcLL) are being implemented in teachers' classrooms.
\end{abstract}

Two non-native-speaking (NNS) Japanese language teachers from a selective secondary school in NSW were interviewed and their classes observed over three days. Analysis of interview and observation data shows that these teachers teach culture as determined by language content, integrate language and culture teaching and teach culture as observable and factual. The study shows that both teachers view culture teaching as easier than language teaching, however their views on the influence of the syllabus differ. The study explores the teachers' past experiences and how these affect how they feel towards, and teach culture. Finally, this study looks at how the teachers' practices reflect concepts of IcLL such as integrating language and culture, student-centred learning and how their status as NNS teachers affects their culture teaching.

\section{Keywords}

Intercultural language learning, language teaching pedagogy, theories of culture teaching, teacher cognition, non-native-speaking teachers

\section{Introduction}

It is becoming widely acknowledged that communicative competence is not the only goal of language learning. Culture is inseparable from language and it is only through an intercultural approach to language teaching and learning that effective 
communication and intercultural understanding can occur. Inquiry into Intercultural Language Learning (IcLL) began around a decade ago and is entering mainstream approaches to languages education. One of the key messages from a recent Australian national seminar on languages education was to encourage an intercultural approach. ${ }^{1}$ Although research exists on how IcLL has been integrated within curriculum frameworks, ${ }^{2}$ there has been little attention paid to how culture is currently being taught in the classroom and whether it reflects the goals of IcLL. This study hopes to shed some light on this area by asking how Japanese language teachers in one case study school teach culture and why. The study involved interviewing and observing the classes of two non-native-speaking (NNS) teachers of stages 4 and 5 Japanese at a Sydney secondary school.

The theoretical orientation of the study is the intersection of the areas of teacher cognition, language and culture teaching and NNS teachers. Teacher cognition refers to 'the unobservable cognitive dimension of teaching - what teachers know, believe and think. ${ }^{3}$ The field of teacher cognition recognises that teachers' behaviour is governed by decision-making influenced by their knowledge, thoughts, beliefs, teaching context and past experiences. ${ }^{4}$ It should be noted, however, that this study relates to teacher cognition as a teacher's thoughts, beliefs and knowledge rather than cognition as it is referred to in educational psychology. ${ }^{5}$ The second of these theoretical orientations is language and culture teaching, concepts which will be explored in detail in the literature review.

The third of these theoretical orientations relates to NNS teachers. NNS teachers are generally defined as not possessing the characteristics of native speaking (NS) teachers which, although not universally agreed upon, include acquisition of the language during childhood, intuitions about grammar, wide-ranging communicative competence and the ability to write creatively in the language. ${ }^{6}$ Whereas the differences in language proficiency between NS teachers and NNS teachers are contested, in a sociolinguistic sense NS teachers are associated with confidence and authority over the target language. The merits of NNS teachers and how they can contribute to IcLL are considered further in the next section.

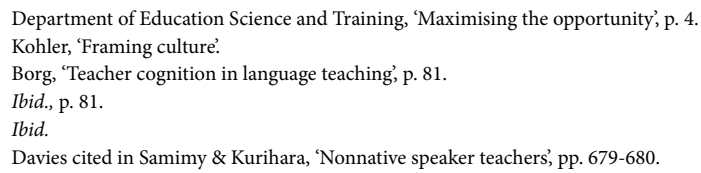




\section{Literature review}

'Intercultural language learning is the biggest change in language teachers' practice since the 1980s ... offering the chance to deepen the learning experience by encouraging social interaction, making connections with other learning areas and supporting self-reflection.'

Lia Tedesco

Australian Federation of Modern Language Teachers Associations ${ }^{7}$

The main premise of IcLL is that language and culture are inseparable. It is impossible to communicate in a language without understanding the cultural connotations of its use. Likewise, it is impossible to understand a different culture without learning how different ideas and ways of seeing the world are expressed through its language. As 'foreign languages are not just a code version of English,' ${ }^{3}$ culture is not just another component to be tacked onto the end of the code - it is embedded within it. ${ }^{9}$

Kramsch says that every time we speak, we perform a cultural act. ${ }^{10}$ When we speak the words we use reflect our identity and the cultural context we are in. We choose certain words to express politeness however the degree of politeness necessary in different situations comes down to culture. For example, learning the grammatical differences between plain, polite and honorific form in Japanese and trying to use them according to Australian norms cannot lead to successful communication. ${ }^{11}$

Unlike communicative language learning that uses a model of native speaker dialogue, the model for IcLL is communication between native and nonnative speakers. ${ }^{12}$ This allows for recognition that the students' native culture and language will affect their communicative needs and resources. ${ }^{13}$ IcLL aims to take a constructivist approach by valuing a student's native language and culture and starting language study from that point. ${ }^{14}$ Therefore in IcLL, mimicking native speakers is no longer the goal of language learning. ${ }^{15}$ In an interesting turn, this also means that practices that are less native-like can be seen as progress in IcLL, as the student has obviously reflected on their own culture and negotiated a 'third place' for themselves. ${ }^{16}$ The third place is a negotiation between ones native culture and

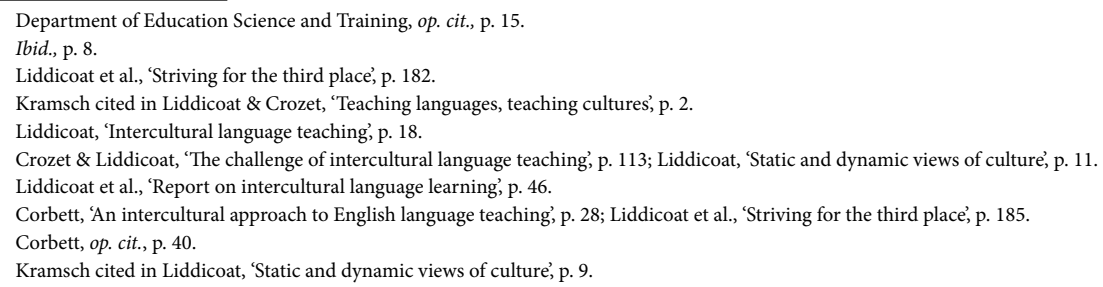


the target culture and is represented in the NSW languages syllabus through the objective 'moving between cultures.' ${ }^{17}$ (see Figure 1).

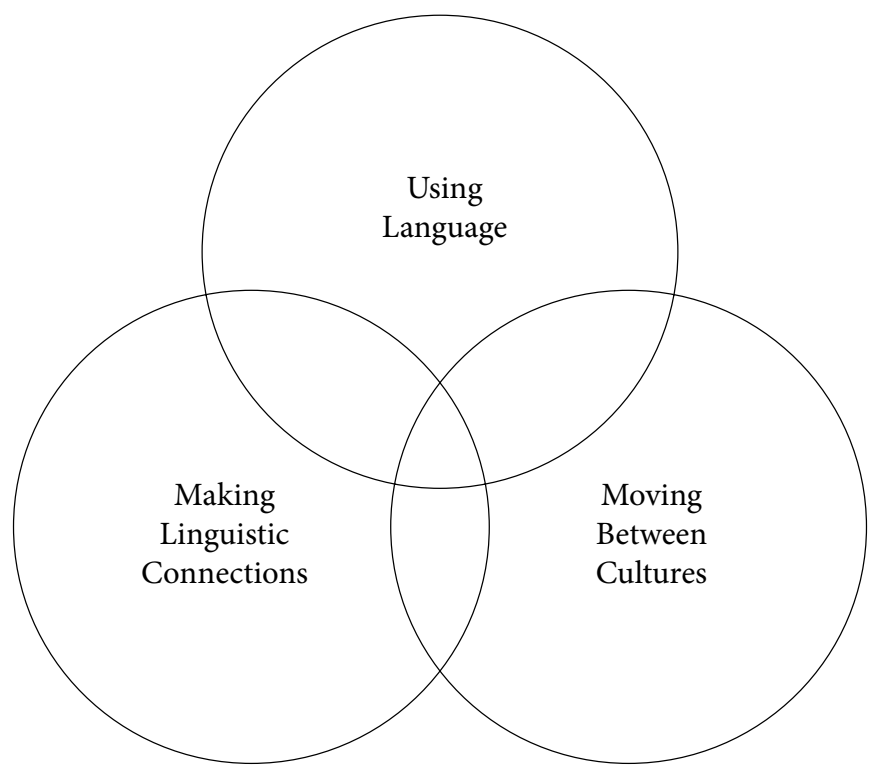

Figure 1: The three objectives outlined in the NSW K-10 Japanese Syllabus. ${ }^{18}$

In reviewing literature for the study, both traditional culture teaching approaches and IcLL approaches were investigated. One traditional approach to teaching culture is avoiding cultural content in lessons due to students' low language proficiency or only teaching culture for the exact same reason. ${ }^{19}$ Saving culture lessons for late afternoons or the end of term because they are perceived as being easier to teach than language-based lessons is another traditional approach to culture teaching. ${ }^{20} \mathrm{In}$ contrast to these traditional approaches, intercultural approaches assert that language and culture should be taught in an integrated manner ${ }^{21}$ and that culture lessons should be intellectually stimulating. ${ }^{22}$ This study was also informed by literature examining the intersection of IcLL with other areas such as the role of resources, intercultural skills and NNS teachers.

17 Board of Studies, 'Japanese K-10 syllabus', p. 14.

18 Board of Studies, 'Japanese K-10 syllabus', p. 14.

19 Liddicoat, op. cit., p. 9; Byram et al. cited in Paige et al., op. cit., p. 37.

20 Kaikkonen, 'Intercultural learning through foreign language education', p. 61.

21 Liddicoat, op. cit., p. 9; Liddicoat \& Crozet, 'Teaching languages, teaching cultures', p. 14; Liddicoat, 'Intercultural language teaching', p. 18.

22 Byram, 'Commentary', p. 230; Kohler, op. cit., p. 17; Kramsch cited in Paige et al., op. cit., p. 43. 
It is common for teachers to use cultural content from textbooks, which is usually derived from the communicative topic being studied at the time such as ordering food or travelling. ${ }^{23}$ Galloway outlines the following common approaches to teaching culture:

- The Frankenstein approach 'a taco from here.... bullfight from there';

- The $4 \mathrm{~F}$ approach (folk dances, festivals, fairs and food);

- The tour guide approach (geography);

- The 'by-the-way' approach when teachers share anecdotes or offer bits of information to illustrate a point. ${ }^{24}$

In communicative textbooks, cultural content can usually be defined as static culture (that which does not change and can be learnt as facts) and does not reflect the needs of a user of the language..$^{25}$ For example, information on the speed of trains in Japan might accompany an exercise on how to buy a train ticket. This approach to culture as an 'add-on' may be practical in a communicative sense, however 'it does not always give rise to a very stimulating educational experience' as topics and issues are dealt with on a superficial level. ${ }^{26}$

IcLL skills are represented by Moran's Cultural Knowings Framework which refers to four 'knowings': Knowing About, Knowing How, Knowing Why and Knowing Oneself. 'Knowing About' refers to knowing facts about products, practices and perspectives of the culture. 'Knowing How' relates to acquiring cultural practices knowing how to act in the culture. 'Knowing Why' requires an understanding of the cultural perspectives - perceptions, values and attitudes. Finally 'Knowing Oneself' means acknowledging one's own values, perspectives and feelings. ${ }^{27}$ Teachers can give their students opportunities to use these skills by relinquishing their role as 'the provider of facts. Rather than giving out information, teachers can plan activities for students to investigate and find 'answers' to cultural question ${ }^{28}$ and act as mediators between their students and the target culture. ${ }^{29}$

The concept of mediation between cultures is related to the merits of NNS teachers, who are thought to be more adaptable to the inconsistencies of language and culture. NNS teachers approach these areas with a 'unique multilingual perspective,'

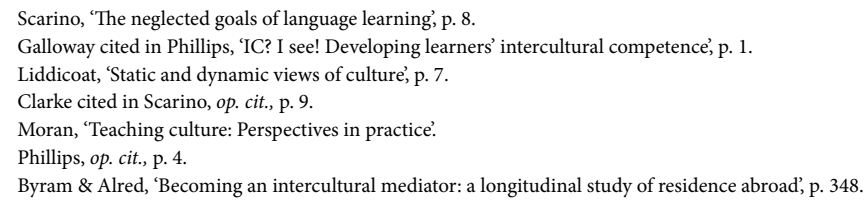


- a privilege that even native speakers do not have access to. ${ }^{30}$ Some would believe, however, that a native speaker represents the culture automatically whereas NNS teachers must try much harder and it is perhaps this extra effort required that make NNS teachers valuable for IcLL. ${ }^{31}$ As they have learnt both the target language and culture from scratch, they can serve as good role models for their students. ${ }^{32}$ They have had to learn about the target culture explicitly unlike native speakers, and also may have had to reflect on their own culture to negotiate a 'third place' in which to operate. ${ }^{33}$

\section{Research design and methodology}

The research questions developed for the study were:

1. How do NNS Japanese language teachers teach culture in the case study school?;

2. What are their attitudes toward and beliefs on teaching culture and how have they been influenced by their past experiences?;

3. How do their teaching practices and thoughts on teaching culture reflect the concepts of Intercultural Language Learning?

The study focused on two teachers in a particular school. A case study was chosen in order to 'provide a holistic description of language learning ... within a specific population and setting. ${ }^{34}$ Although generalisations about how Japanese teachers teach culture and why cannot be made from this small study, it contributes to the field by providing insights into the complexities of two teachers' experiences within the same context and serves to highlight different influences on a teacher's thoughts and behaviour. ${ }^{35}$

The study utilised two data collection measures. Teachers were interviewed to find out their views on teaching culture and how their beliefs and practices are influenced by prior experiences and several of the teachers' classes were observed to look for evidence of culture teaching. The sample - two NNS Japanese language teachers teaching stages four and five at a Sydney secondary school - choice was a combination of convenience and purpose: ${ }^{36}$ convenience because the researcher taught there for

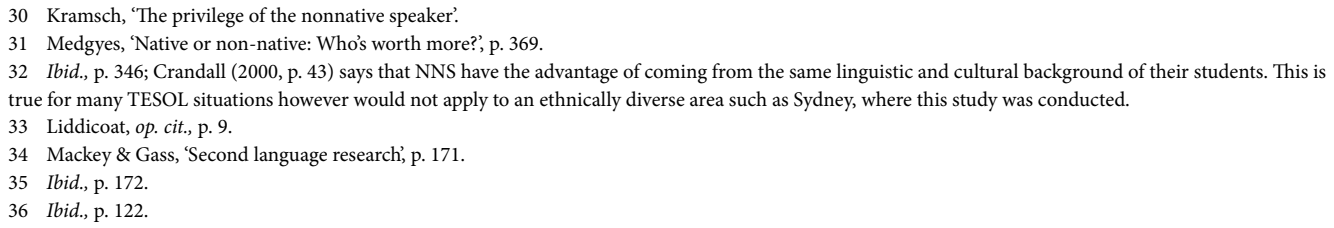


four weeks on practicum and the teachers were willing to participate; and purposive as the school was co-educational and thus eliminated any opportunity for bias within culture teaching arising from teaching groups of all boys or all girls. The school was also suitable for this case study as there were two NNS Japanese language teachers on staff with significantly different backgrounds and teaching experience. Only NNS Japanese teachers were involved because the depth required to compare experiences and beliefs of NS and NNS was beyond the scope of this study.

The case school is a selective co-educational secondary school in suburban Sydney. The majority of students at the school are from Asian backgrounds and this majority is even more pronounced in Japanese classes. Jane ${ }^{37}$ teaches Years 8 and 9 and, less frequently, Year 10 and 11 classes. She is employed three days a week, one of which is designated to English as a Second Language (ESL). Arthur works full time and is also Head Teacher of Administration. He takes a Year 7 class for a taster course of French, German, Japanese and Latin once a week, Years 10 and 11 the majority of the time and all Year 12 classes.

Data collection procedures included document analysis, interviews, observation and personal communication. The LOTE, languages other than English: strategic plan consultation document ${ }^{38}$ and the NSW K-10 Japanese syllabus ${ }^{39}$ were analysed for references to directives for teaching cultural content.

Interviewing was chosen as a data collection procedure in order to elicit how a teacher feels about culture teaching, how they assess their approach, their classroom practice and their motivations for teaching the way they do. Interviews give teachers the opportunity to express approaches to culture teaching that may not be observable and give information about how their past experiences have affected their culture teaching. ${ }^{40}$

Interviews were semi-structured in format and conducted over two days in June 2007. Interviews were audio-recorded, transcribed and analysed. Interview questions were designed to assess teachers' beliefs about teaching culture, their past and present interactions with Japanese culture, their feelings about their ability to teach culture and their non-native speaker status and their opinions on policies and professional development relating to culture teaching.

Observation of classes allowed the researcher to witness how teaching plans are

\footnotetext{
Pseudonyms for both teachers chosen by researcher.

8 New South Wales Department of School Education, 'LOTE'.

9 Board of Studies, op. cit.

0 Mackey \& Gass, op. cit., p. 173.
} 
implemented and how students respond to culture teaching. Multiple observations were undertaken to develop a 'more multilayered understanding of the participants and their context. ${ }^{41}$ The observations were semi-structured in that they were planned and previously established categories were used, however the categories were broad and allowed the researcher to include field notes. ${ }^{42}$ Observations were not audio or video recorded. A total of nine lessons were observed over the same two days the interviews were conducted.

Class observation coding sheets based on a category system were developed to record instances of culture teaching in the classroom. ${ }^{43}$ Categories were developed according to themes explored in the literature review, such as teacher-centred culture teaching, student-centred culture teaching and integrated language and culture teaching. The data analysed for the literature review enabled the researcher to recognise relevant instances of behaviour and note them down. ${ }^{44}$ Further clarification on interview and observation data was obtained through personal communication via email with the participating teachers.

Two data collection measures were used in order to result in the same research findings through triangulation. The combination of interviews that assess self-reported behaviour and observations that assess actual behaviour results in triangulation. ${ }^{45}$ By collecting data through two means, the researcher's bias is reduced, a richer case study can be created ${ }^{46}$ and the study's validity is increased, as one method can further explore findings not accessible through the other. ${ }^{47}$

A pilot interview and class observation with a NNS Japanese teacher not involved with the study was also carried out to uncover any problems with the proposed procedures. ${ }^{48}$ As well as some interview questions, the classroom observation instrument was modified after the pilot observation. Specific categories such as those referring to tasks, activities, anecdotes and reflection in the earlier version were modified to become the broader categories of:

1. Culture being generated by the teacher;

2. Culture being elicited by the teacher;

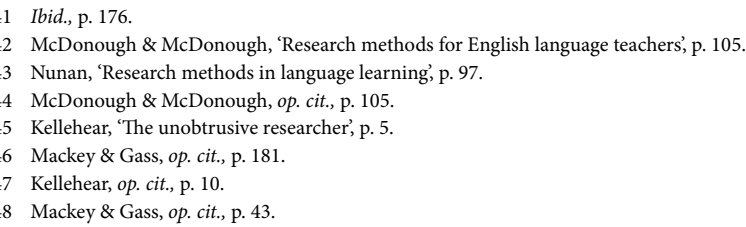


3. Culture being generated by the students;

4. Language and culture integration.

Interview data, observation data and personal correspondence were analysed in accordance with data gathered during the literature review, the NSW K-10 Japanese syllabus and NSW strategic plan for languages released in 1992 in order to explore the research questions. Findings were then collated into the following table to assist in answering the research questions.

Table three: Research questions, data sources and analysis

\begin{tabular}{|l|l|l|l|}
\hline Research Questions & $\begin{array}{l}\text { Data source 1 } \\
\text { Interviews }\end{array}$ & $\begin{array}{l}\text { Data source 2 } \\
\text { Observations }\end{array}$ & $\begin{array}{l}\text { Coding } \\
\text { /analysis }\end{array}$ \\
\hline $\begin{array}{l}\text { How do NNS Japanese } \\
\text { language teachers teach } \\
\text { culture in the case study } \\
\text { school? }\end{array}$ & $\begin{array}{l}\text { - As determined by language } \\
\text { - As integrated with language }\end{array}$ & $\begin{array}{l}\text { - As observable } \\
\text { culture } \\
\text { - As facts }\end{array}$ & $\begin{array}{l}\text { Content } \\
\text { analysis }\end{array}$ \\
\hline $\begin{array}{l}\text { What are their attitudes } \\
\text { toward and beliefs on } \\
\text { teaching culture and } \\
\text { how have they been } \\
\text { influenced by their past } \\
\text { experiences? }\end{array}$ & $\begin{array}{l}\text { - Teaching culture is easier } \\
\text { than teaching language } \\
\text { - Influence of the syllabus } \\
\text { - Previous culture teaching } \\
\text { and learning experience }\end{array}$ & $\begin{array}{l}\text { - That speaking } \\
\text { cultural act }\end{array}$ & $\begin{array}{l}\text { Content } \\
\text { analysis }\end{array}$ \\
\hline $\begin{array}{l}\text { How do their teaching } \\
\text { practices and thoughts on } \\
\text { teaching culture } \\
\text { reflect the concepts of } \\
\begin{array}{l}\text { Intercultural Language } \\
\text { Learning? }\end{array}\end{array}$ & $\begin{array}{l}\text { - Language and culture } \\
\text { integration } \\
\text { Native speaker is not the } \\
\text { ideal }\end{array}$ & $\begin{array}{l}\text { Dradent-centred learning } \\
\text { students' prior } \\
\text { knowledge }\end{array}$ & analysis \\
\hline
\end{tabular}

\section{Findings and discussion}

\section{Demographic information}

Jane's first year of teaching Japanese was in 2007, although she had been teaching ESL in schools since 2001. Jane and her family immigrated to Queensland when she was a child 
and her family spoke English and Cantonese at home. ${ }^{49}$ She studied Japanese at high school and Japanese and Chinese at university. She lived in Japan and taught English for three years and also taught English in China for 2 months at the end of her teaching degree. Arthur has been teaching languages (French and Latin) since 1980 and Japanese since 1981. He describes the place where he grew up as a conservative Caucasian community in rural New South Wales. At university he studied to be a French and Latin teacher and began studying Japanese because it was a requirement of his course. Arthur has not lived in Japan but has travelled there nine times, accompanying students on six of those trips.

\section{Culture teaching in the classroom}

When speaking to both teachers about their culture teaching practice it was discovered that, to a large extent, the language content being covered in class determines how the teacher decides what to teach as cultural content. Arthur described how cultural content was chosen depending on whether it was related to the language under study: 'If you teach family you teach about Japanese families, if you're teaching transport you teach about Japanese transport.' Jane stated that the language and culture under study in the textbook guided her culture teaching: 'We cover topics in the modules, in the textbook. I sort of fit it in around that, almost like the language dictates the culture.' While Arthur seemed to accept this way of structuring culture content around the communicative function, Jane seemed somewhat disappointed that culture was not playing a more central role in her lessons. This issue reflects Scarino's research that says cultural content in textbooks is derived from the language topic of study and is treated as an 'add-on' to the main educational objective - developing communicative skills. ${ }^{50}$

In IcLL the main educational objective is what you want the students to understand about the target culture, and the language content necessary to meet that objective is then devised. In this case study, language and culture are connected by the teacher setting a communicative goal, setting language structures to be covered and then 'adding-on' the cultural content. Integrating language and culture teaching refers to combining language and cultural content in the same lesson and designing the outcomes according to cultural goals as well as language goals. Jane demonstrated her beliefs about how language and culture are integrated when explaining how she incorporated Japanese culture in her lessons:

49 Jane, Personal Communication, August 8.

50 Scarino, op. cit., p. 8. 
Right from the very beginning we begin with what I expect in class and especially I guess things like standing up when the teacher comes in and bowing, greeting at the beginning of the lesson and also at the end of the lesson.

We discuss Japanese writing and things that I guess are borrowed from Chinese culture or Korean culture.

Jane's comments on how the students should use greetings in class reflect that she sees the Japanese words as being embedded with contextual meaning and wants her students to experiment with performing a cultural act when they come to class. ${ }^{51}$ Her comment on Japanese writing as also having a cultural origin shows that she considers both spoken and written communication as having a cultural context. Arthur reported that he believed language and culture teaching should be integrated and so was undertaking the Intercultural Language Teaching and Learning in Practice (ILTLP) ${ }^{52}$ project to extend his knowledge in the area.

A theme that arose during classroom observations was that culture was taught as a visible, tangible entity. During a lesson watching a Japanese animated film, Jane often elicited cultural information from students based on what they could see, such as the film's setting. Students also related to this visual approach by making comments about what they saw such as noticing the characters sleeping on futon on the floor.

Teaching culture as something that is observable can harness two of what Moran termed cultural knowings. ${ }^{53}$ By watching a film, students are 'knowing about' products of culture such as a futon and practices such as sleeping on the floor and are also 'knowing how' Japanese people act in certain situations. ${ }^{54}$ Although Arthur did not use visual stimulus in any of the lessons observed during the limited observation period, he referred to things the students had seen in previous lessons or on trips to Japan such as paper cranes at Hiroshima's Atomic Dome and Asakusa's famous red lantern.

Both teachers demonstrated that they think of culture as having a factual basis. The concept of 'background knowledge' was often present, for example when Jane gave her students information on the director of the film they were watching and his motivation for making it. Arthur also referred to facts when asking students what Okinawa was famous for. While the answer he was expecting (tourism) did not come from the students, their responses were diverse. The students made reference to seafood,

\footnotetext{
1 Kramsch cited in Liddicoat, 'Intercultural language teaching: principles for practice', p. 18.

52 The ILTLP was a professional development project for language teachers funded by the Federal Government's Department of Education, Science and Training.

53 Moran, op. cit.

54 Ibid.
} 
American military bases and tanned people in manga which suggests their background knowledge of Japanese culture extends from history to geography to popular culture. This highlights the idea that even facts are not static culture and are subjective. ${ }^{55}$ Resources and even teacher anecdotes are subjective and can become part of the 'hidden curriculum'(cultural values indirectly communicated through content choices). ${ }^{56}$

\section{Culture teaching - attitudes, beliefs and past experiences}

During interviews both teachers alluded to the idea that culture lessons are easier than language lessons for both teachers and students. Jane said:

It feels like it's easier to teach culture... after writing reports and doing assessments and what not I guess it's a little bit easier to prepare those sorts of lessons. Also you can show media as well, show movies... in a way that is teaching culture by them just watching... I suppose you do save it up for these times when you do have time to relax and the students have time to relax.

This statement can be seen as reflecting both Jane's status as a beginning teacher as well as her experiences learning about Japanese culture. As Jane acquired most of her cultural knowledge while living in Japan, it is natural that she uses her familiarity with culture to create lessons for her students when she is feeling overworked. The fact that she acquired her knowledge through immersion in the culture is also evident in her opinion that the students will learn about Japanese culture by passively observing what is depicted in films. Reflecting the viewpoint of the students, Arthur said:

You can talk from your own personal experiences as you're going along. It's nice to add little anecdotes... and some students have actually said that they really enjoyed the little stories and anecdotes as they were studying Japanese after they'd left because they said it was nice to break up the lesson with something like that.

Arthur's comment reflects the idea that culture can be added to lessons using the 'by-the-way' approach ${ }^{57}$ and that students appreciate this as a welcome break from studying language, which is more intellectually demanding. ${ }^{58}$ It also suggests that students appreciate the personal dimension anecdotes give and that they are curious to hear about their teacher's experiences in and knowledge of Japan.

\footnotetext{
Liddicoat, 'Static and dynamic views of culture', p. 7; Stodolosky and Grossman cited in Paige et al., p. 33.

6 Liddicoat et al., 'Report on intercultural language learning', p. 52; Cunningsworth cited in Tudor, op. cit., p. 73.

Galloway cited in Phillips, op. cit., p. 1.

8 Kaikkonen, op. cit., p. 61.
} 
Both teachers viewed the influence of the syllabus on their culture teaching differently. Arthur commented that teaching gifted and talented students, who usually get through the required syllabus content quite quickly, allowed for freedom within the syllabus and other policies:

There are certain policies that you have to fulfil... and sometimes you can actually fulfil those policies by use of the cultural side of things. But there's a big push of course to integrate the culture these days and if you're actually sort of making use of some policy to satisfy a requirement that's almost like taking the cultural aspect out and doing it as a separate entity, which is now going against the flow. It should all be part and parcel of the one approach.

Arthur's participation in the teacher professional development project, the ILTLP, is also evident here as he recognises that using cultural content to satisfy policy requirements goes against the principles of IcLL to a certain extent. ${ }^{59}$ Jane, on the other hand, sees the syllabus as a hindrance to her ability to teach culture:

Maybe it's just because I'm beginning and I'm finding it difficult to do everything I need to do and also make it interesting for students. I just feel that culture and language are so connected that it's necessary to have a lot of culture so it does make sense for the students and... [they] take more of an interest.

It is interesting to note that the K-10 syllabus specifies very little in terms of specific language content to be covered. It is perhaps, therefore, more the textbooks Jane and Arthur use than the syllabus that restrict their freedom to teach culture and determine the language they teach. The strongest influence on a teacher's implementation of IcLL, however, is not curriculum frameworks but their own values and attitudes that are in turn influenced by their past experiences. ${ }^{60}$

Arthur discussed his experiences of language and culture being taught separately. When he was learning languages at high school, one lesson per week was set aside as a 'culture lesson' and this approach was also encouraged when he was completing teacher training at university. There was no integration between language and culture, to the extent that students had a separate culture book to bring along for their culture lesson and could leave their grammar book at home:

59 Cross-curriculum Content, intended to achieve broad learning outcomes, is specified in the Japanese K-10 syllabus through incorporating objectives such as Information and Communication Technologies, Civics and Citizenship and Difference and Diversity.

60 Liddicoat, et al., op. cit., p. 43; Sercu et al., op. cit., p. 484. 
I remember running off reams and reams of cultural notes to discuss with the students and you'd hand out seven or eight pages just because you'd have to introduce the culture and discuss the culture and everything else with the students on that particular day...It was just ridiculous because you were doing things that really didn't relate to what you were teaching in the grammatical lessons just because you had to fill up your culture lesson.

Arthur's belief that language and culture teaching should be integrated is a reaction against the way he was taught at school and university. In her interview, Jane also reflected on learning calligraphy and looking at pictures of kimono and temples in high school Japanese classes, however her experiences in Japan have had a far greater impact on how she views the teaching and learning of culture: 'It's just an idea when you're studying it in the classroom and it's not this real thing... Well obviously when you're there in Japan it hits you. Wow. It hits you in the face.' She also said that she wanted to discuss Japanese popular culture with the students and try to use authentic materials to engage them. Finding authentic materials that were at a level appropriate for both the students' language proficiency and age proved difficult, however, reflecting the challenge of modifying resources yet keeping them authentic and motivating for students. ${ }^{61}$

Jane sees speaking Japanese as automatically engaging with the culture due to her past experiences living in Japan. An example of this is giving classroom greetings and instructions in Japanese and having the students stand and bow to the teacher before the class starts. Jane also uses the word 'prints' for the photocopied handouts she gives the students and this comes from the Japanese word for such items (albeit derived from English) 'purinto'. She says that this is something she picked up in Japan and consciously decided to use in her lessons. ${ }^{62}$ As well as Kramsch's concept of speaking as a cultural act ${ }^{63}$ Jane's classroom also demonstrates aspects of the third place. ${ }^{64}$ Through using Japanese language and customs in the classroom, Jane's students are experimenting with a third place and also 'moving between cultures' as the NSW syllabus directs. Arthur encourages students to think about their own third place by discussing with them their own knowledge of Japan and experiences there. When discussing some class work referring to the Golden Pavilion in Kyoto, which some of the students had visited, he questioned the use of the word kirei (pretty) to describe it, suggesting to the students that a Japanese person would be more passionate in their description because they would feel proud of it.

\footnotetext{
Liddicoat, et al., op. cit., p. 67

2 Jane, Personal Communication, September 10.

3 Kramsch cited in Liddicoat and Crozet, 'Teaching languages, teaching cultures', p. 2.

64 Kramsch cited in Liddicoat, 'Static and dynamic views of culture', p. 9.
} 


\section{Teachers' thoughts, practice and IcLL}

During her interview, Jane often expressed sentiments that she wished to integrate language and culture learning more in her lessons:

I feel like often in class I'll just go in and say 'ok this is the topic and this is the language we're learning today' and you know 'here's the vocab' and 'this is how we put these sentences together' and I think ... they're just words you know. And if you do pre-teach culture and teach the students 'ok we use this in this situation' I think they'd definitely be a lot more motivated to learn the language and also be more interested in learning about Japanese culture. They might learn the language because of that.

Although Jane was not familiar with IcLL and had not received any professional development in the area, her experiences living in Japan mean she is aware of the underlying concepts of IcLL and tries to incorporate them in her teaching. She also recognises the potential for cultural content to contextualise language learning, spark interest and motivate students. ${ }^{65}$

Arthur supported integrating language and culture because he viewed it as a holistic and balanced way of teaching. He saw integration as a good way to cater for students who were keen to focus on language content: 'They've come to learn to speak and to read and to be more confident in the language ... increasing the amount of culture they're doing is not perhaps going to help them in that so that's why if it's integrated it's much better.' One of the points that arose in the literature review was the idea that native speaking practices are not always the ideal in IcLL. Since the literature on NNS teachers focuses on language rather than culture teaching, comments Arthur made on the differences are very interesting:

Well a native speaker, I've always felt, tends to teach the culture because they've lived the culture but I don't know whether sometimes the amount of culture or the appropriateness of it might apply... I tend to pick and choose and wait to see what the reaction is with the students as to whether they are interested in this particular thing or not.

This quote suggests that, as a NNS teacher, Arthur feels somewhat privileged when teaching culture as, since he does not have any personal connection with the culture, he can look at cultural content objectively and choose aspects that are most appropriate for his students. This relates to the privilege Kramsch talks about in non-

65 Byram cited in Corbett, op. cit., p. 25; Paige et al., op. cit., p. 30; Tudor, op. cit., p. 72. 
native speakers having a 'unique multilingual perspective' and suggests that maybe NNS teachers also have a 'unique multicultural perspective'.66

Arthur also describes how a NS teacher's personal connection with the target culture may affect their willingness to teach aspects of culture that they see as problematic: 'I know some of them are horrified to teach anything that's modern or new thinking because it might be looked upon as if it's their thinking and so they won't teach it.' The idea of teaching controversial aspects of culture supports Byram's maxim to get past the superficial and stereotypical aspects of culture by challenging everything and further suggests the ability of NNS teachers to successfully teach interculturally. ${ }^{67}$ While this is only one teacher's opinion on the differences between his own and NS teachers' ways of teaching culture, it raised some interesting issues. Jane's perspective on being a NNS teacher was that she did not see any difference between her ability to teach culture and that of a NS teacher except that a NS teacher may have more access to resources. Whereas other Australian studies on NNS language teachers found they felt insecure due to their language proficiency, ${ }^{68}$ the teachers interviewed for this study do not feel they have any disadvantage when teaching culture. If anything, Arthur's comments show that he feels his ability to teach culture is enhanced because he is removed from the culture unlike a native-speaker. Jane and Arthur's positive attitudes toward teaching culture also reflect Medgyes' idea that NNS teachers can serve as good role models for their students. ${ }^{69}$

Arthur believed his students had significant background knowledge of Japan and were able to find answers to cultural questions for themselves. In his interview, Arthur spoke about his aim to make cultural content student-centred:

The students' interest in music and anime, I tend to leave to them because I know that they'll go on the internet and find those things... I'm not an expert in that field. But some of them really are expert in that field and perhaps it's actually something they could share with the rest of the class.

I think it's important to know the clientele a little bit better... what are their interests, what do they know, what comparisons can they make between their own culture and that of the Japanese and their experience of living in Australia.

Jane also mentioned the student's interests in her interview: 'I'm often asked questions about popular music or you know, popular culture that teenagers are interested in

\footnotetext{
66 Kramsch, 'The privilege of the nonnative speaker', p. 252.

67 Byram, 'Commentary', p. 330.

68 Armour, 'Becoming a Japanese language learner, user and teacher', pp. 114-116.

69 Medgyes, op. cit., p. 346.
} 
and I have no idea about that anymore.' It is interesting to compare Jane and Arthur's responses while considering that Arthur is undertaking professional development in IcLL and Jane is not. Arthur feels that he can surrender his role as the provider of facts $^{30}$ and let his students develop their intercultural skills by investigating things for themselves. Jane, however, feels as though it is her responsibility to gather facts and knowledge her students may be interested in.

Both Jane and Arthur were drawing on students' prior knowledge when teaching Japanese culture. Before students watched the animated film, Jane asked them what they thought Japan was like, to which they replied anime, advanced technology, mountains, cherry blossoms, shopping and food. The film being shown was set in rural Japan in the 1950s which gave the students a different perspective to the ones they were familiar with and Jane asked them to think about their impressions of Japan while they watched. Arthur prompted students for information about places in Japan they had been to or learnt about and also had them reflect on their own background. When he compared the town of Hahndorf in South Australia (which featured in a reading passage) to Old Sydney Town the students could instantly relate to the context. By using a film that contrasted with students' perceptions of Japan, Jane was introducing them to a variety of perspectives to achieve IcLL. ${ }^{71}$ Arthur encouraged students to use their own background and past experiences to better understand something new, thus utilising Moran's concept of Knowing Oneself ${ }^{72}$ and the skills of comparing and reflecting. ${ }^{73}$ Jane and Arthur also both demonstrated the IcLL concept of valuing a student's background and prior knowledge. ${ }^{74}$

\section{Conclusion}

This case study has shed light on how two NNS teachers from different backgrounds teach culture in their classrooms. The two teachers are similar in the following ways:

- Both currently teach culture content that is determined by the language content being covered at the time;

- Both teachers expressed that they thought language and culture teaching should be integrated;

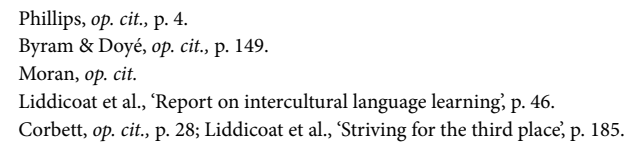


- Both teachers see culture as being both observable and factual to a certain extent and thus teach using films and anecdotes to engage and inform students.

Jane and Arthur teach culture differently because:

- Jane creates a third place through using Japanese language and customs in the classroom;

- Arthur creates a third place by encouraging students to reflect on their own background and experiment with Japanese perspectives.

Jane and Arthur share the belief that culture is easier for teachers to teach and for students to learn. Despite having different backgrounds, both teachers' attitudes towards teaching culture were influenced by their past experiences:

- Arthur was determined to move away from his own experiences of learning and teaching culture as a separate subject to language;

- Jane was keen for students to experience Japanese culture in an authentic way, as she herself experienced it by living in Japan.

Jane and Arthur also saw culture teaching differently in terms of the syllabus.

- Arthur was confident the requirements could be covered while allowing time for other things;

- Jane felt, as a beginning teacher, somewhat stifled by the syllabus.

With regards to teaching practices and thoughts on teaching culture, the two teachers differ because:

- Jane has undergone no professional development in IcLL while Arthur has;

- Arthur's ILTLP project training has encouraged him to allow the students more input into the curriculum whereas Jane feels she must broaden her own knowledge in order to appeal to the students' interests. 
However their thoughts on teaching culture both reflect concepts of IcLL because they:

- do not feel they have a disadvantage when teaching culture due to their non-native speaker status;

- agree with the IcLL concept of making learning more student-centred.

\section{Implications}

This case study of two Japanese teachers in a NSW secondary school has raised issues that many teachers will be able to relate to. It has shown how two different teachers teach culture in their classrooms and other teachers can use this information to reflect on their own practice. It has also explored some of the reasons why Jane and Arthur teach the way they do which highlights the role of a teacher's thoughts, attitudes, knowledge and past experiences in shaping their practice. The study also highlights instances of IcLL in Jane and Arthur's classrooms which will help teachers to identify and implement such practices in their own lessons.

This study also has implications for policy makers as it shows how two teachers are interpreting and implementing the NSW K-10 Japanese syllabus and especially the objective of 'moving between cultures'. It also profiles two teachers from NSW and shows their attitudes and beliefs on teaching culture as well as how their past experiences have influenced their teaching. Policy makers can take note of these attitudes, beliefs and past experiences and reflect on how pre-teacher education and professional development opportunities can assist teachers in implementing the syllabus objectives successfully. This study can also show policy makers how teachers are currently implementing IcLL in their classrooms.

\section{Further research and concluding thoughts}

As the teachers participating in this study were both working at an academically selective school, researching the experiences of teachers working at other schools could contribute to this field of study. Investigating the experiences of teachers who have completed the ILTLP to discover how they have implemented IcLL and their opinions on its success in the classroom would also be revealing.

Further research could incorporate the reflections of students on the cultural content in their Japanese lessons and determine whether culture teaching in classrooms 
contributes to students' intercultural competence. A broader study including NS teachers could shed light on the effect of teachers' language and cultural backgrounds on their culture teaching practices. In the same vein, a study including teachers from a wide range of schools could determine the effect of students' backgrounds, school culture and curriculum demands on culture teaching.

Australia's capacity to participate in global spheres such as politics and economics is often associated with its ability to cultivate foreign language skills amongst its citizens. The ability of Australians to interact successfully in various language and cultural contexts, especially within the Asia-Pacific region, is a current concern of many and it is for this reason that further research on IcLL and its implementation in schools is necessary. As Japan continues to be a strong diplomatic and economic partner of Australia, the teaching of Japanese continues to thrive in Australian schools. In order for this relationship to continue, the teaching of Japanese must be regularly analysed and updated to reflect the needs of both countries.

This case study has shed light on how two NNS Japanese language teachers in NSW teach culture and why. They teach culture that is integrated with language and determined by language, that is observable and factual. They are trying to make culture learning more student-centred and help their students develop intercultural skills. They teach culture because it is a break from language teaching and is mandated by the syllabus, but mainly because they believe it is a vital and valuable facet of language learning.

\section{References}

Armour, W. S., 'Becoming a Japanese language learner, user, and teacher: Revelations from life history research', Journal of Language Identity and Education, vol. 3, no. 2, (2004), pp. 101-125.

Board of Studies, Japanese K-10 Syllabus (Sydney: 2003).

Borg, S., 'Teacher cognition in language teaching: A review of research on what language teachers think, know, believe and do', Language Teaching, vol. 36, no. 2, (2003), pp. 81-109.

Byram, M., 'Commentary', Kokusai kenkyū shōkai 'kotoba, bunka, shakai no gengo kyōiku' (International conference 'language, culture, society's language education') (Tokyo: Waseda University, September 17-18, 2005).

Byram, M., \& Alred, G., 'Becoming an intercultural mediator: a longitudinal study of residence abroad', Journal of Multilingual and Multicultural Development, vol. 23, no. 5, (2002), pp. 339-352.

Byram, M., \& Doyé, P., 'Intercultural competence and foreign language learning in the primary school', in Frost, D., and Driscoll, P. (eds.), The teaching of modern foreign languages in the primary school (London: Routledge, 1999), pp. 138-151.

Crandall, J., 'Language Teacher Education', Annual Review of Applied Linguistics, vol. 20, (2000), pp. 34-55. 
New Voices Volume 3

Corbett, J., An intercultural approach to English language teaching (Clevedon, England, Buffalo, New York: Multilingual Matters, 2003).

Department of Education Science and Training, Maximising the opportunity. A report on the national seminar for languages education (2006, October 30-31). Retrieved 31 May 2007, from www.asiaeducation.edu.au/public_ html/reports.htm.

Jane, Personal Communication (2007, August 8).

Jane, Personal Communication (2007, September 10).

Kaikkonen, P., 'Intercultural learning through foreign language education', in Kohonen, V., (ed.), Experiential learning in foreign language education (Harlow, New York: Longman, 2001), pp. 61-105.

Kellehear, A., The unobtrusive researcher - a guide to research methods (St Leonards: Allen \& Unwin, 1993).

Kohler, M., 'Framing culture: How 'culture' is represented in Australian state and territory language curriculum frameworks', Babel, vol. 40, no. 1, (2005), pp. 12-17.

Kramsch, C., 'Culture and language teaching', in Brown, K., (ed.), Encyclopedia of language and linguistics (2nd ed.) (Boston: Elsevier, 2006).

Kramsch, C., 'The privilege of the nonnative speaker', in Blythe, C., (ed.), The sociolinguistics of foreign-language classrooms: Contributions of the native, the near-native and the non-native speaker (Boston: Heinle, 2003), pp. 251-262.

Liddicoat, A., 'Intercultural language teaching: principles for practice', The New Zealand Language Teacher, vol. 30, (2004), pp. 17-23.

Liddicoat, A., 'Static and dynamic views of culture and intercultural language acquisition.', Babel, vol. 36, no. 3, (2002), pp. 4-11.

Liddicoat, A., \& Crozet, C., (eds.), Teaching languages, teaching cultures (Melbourne: Language Australia, 2000).

Liddicoat, A., Lo Bianco, J., \& Crozet, C. (eds.), Striving for the Third Place: Intercultural competence through language education (Melbourne: Language Australia, 1999).

Liddicoat, A., Papademetre, L., Scarino, A., \& Kohler, M., Report on intercultural language learning (Canberra: Department of Education, Science and Training, 2003).

Lo Bianco, J., 'New times, world kids, third place', Kokusai kenkyū shōkai 'kotoba, bunka, shakai no gengo kyōiku' (International conference 'language, culture, society's language education') (Tokyo: Waseda University, September 17-18, 2005).

Mackey, A., \& Gass, S. M., Second language research: Methodology and design (Mahwah, NJ: Lawrence Erlbaum, 2005).

McDonough, J., \& McDonough, S., Research methods for English language teachers (New York: Arnold, 1997).

Medgyes, P., 'Native or non-native: Who's worth more?', ELT Journal, vol. 46, no. 4, (1992), pp. 340-349.

Moran, P. R., Teaching culture: Perspectives in practice (Australia, Boston: Heinle \& Heinle, 2001).

New South Wales Department of School Education, LOTE, languages other than English: Strategic plan consultation document (Sydney: The Department, 1992). 
Nunan, D., Research methods in language learning (New York: Cambridge University Press, 1992).

Paige, R. M., Jorstad, H., Siaya, L., Klein, F., \& Colby, J., Culture learning in language education: A review of the literature (Minneapolis: Center for Advanced Research on Language Acquisition Minnesota Univ., 2000).

Phillips, E., 'IC? I see! Developing learners' intercultural competence', LOTE CED Communique, vol. 3, (2001), pp. 1-8.

Samimy, K., \& Kurihara, Y., 'Nonnative speaker teachers', in Brown, K. (ed.), Encyclopedia of language and linguistics (2nd ed.) (Boston: Elsevier, 2006).

Scarino, A., 'The neglected goals of language learning', Babel, vol 34, no. 3, (2000), pp. 4-11.

Sercu, L., 'The foreign language and intercultural competence teacher: The acquisition of a new professional identity', Intercultural Education, vol. 17, no. 1, (2006), pp. 55-72.

Sercu, L., Garcia, M. D., \& Prieto, P. C., 'Culture learning from a constructivist perspective: An investigation of Spanish foreign language teachers' views', Language and Education, vol. 19, no. 6, (2005), pp. 483-495.

Tudor, I., The dynamics of the language classroom (Cambridge: Cambridge University Press, 2001). 


\section{Notes on Contributors}

\section{Jared Denman}

Jared Denman was awarded First Class Honours in Japanese at The University of Queensland in 2008, after completing an Arts (Japanese)/Education dual degree. He is currently a $\mathrm{PhD}$ candidate with the School of Languages and Comparative Cultural Studies and is examining the transnational experience of ageing among first-generation migrants from the local Japanese diaspora.

\section{Matthew Grubits}

Matthew Grubits graduated from the University of Tasmania in 2008 with Honours in History. He is currently enrolled in a Master of Arts at the University of Tasmania, and is continuing to explore the role of aestheticism in society.

\section{Caroline Mahoney}

Caroline Mahoney graduated from the University of Technology, Sydney, in 2005 with a combined degree in Journalism and Japanese. In 2008 she was awarded First Class Honours in her Master of Teaching at the University of Sydney. She is currently studying Japanese language education at Waseda University, Tokyo, and working towards her $\mathrm{PhD}$.

\section{Christine de Matos}

Christine de Matos is a Research Fellow in the Centre for Asia Pacific Social Transformation Studies (CAPSTRANS) at the University of Wollongong. She is currently analysing the everyday practice of power in relations between Australians and Japanese during the Allied Occupation of Japan (1945-1952). Her recent publications include Imposing Peace and Prosperity: Australia, Social Justice and Labour Reform in Occupied Japan (2008) and a collection of papers co-edited with Robin Gerster titled Occupying the 'Other': Australia and military occupations from Japan to Iraq (2009). 


\section{Jack Nicholls}

Jack Nicholls graduated from the University of Melbourne in 2008 with First Class Honours in History. After dabbling in the outside world for six months, he has now returned to academia to undertake a Master of Environment.

\section{Chikako Nihei}

Chikako Nihei is undertaking a Masters degree by research in Japanese Studies at the University of Sydney. She holds a Master of English literature at the University of Wollongong and a Bachelor of Arts and Science from Tokyo Woman's Christian University.

\section{Sarah Pasfield-Neofitou}

Sarah Pasfield-Neofitou was recently awarded First Class Honours in combined Japanese and Linguistics at Monash University, Melbourne. Currently, Sarah is a $\mathrm{PhD}$ candidate researching second language acquisition and use in Computer Mediated Communication at Monash, where she also works part-time in the school of Languages, Cultures and Linguistics, teaching Japanese language and linguistics. Sarah is the current Postgraduate Liaison for the Japanese Studies Association of Australia. 


\section{New Voices 4: Call for Papers}

New Voices is an academic journal published in print and online by The Japan Foundation, Sydney. The journal's primary aim is to support emerging Japanese Studies scholars by providing a platform for the promotion of outstanding research and writing by students and early career researchers.

The Japan Foundation, Sydney is now seeking submissions for New Voices Volume 4. We are currently soliciting original papers from recent Honours and Masters graduates who completed their Honours or Masters thesis at an Australian or New Zealand University between January 2007 and December 2009. The deadline for submissions is 31 July 2010.

For further information, please download an information package from http://www.jpf.org.au/newvoices.

Or contact The Japan Foundation, Sydney (Japanese Studies and Intellectual Exchange Department):

Ph: 0282390055

Email: newvoices@jpf.org.au 
New Voices Volume 3 


\section{NEW voices}

Volume 3: A Journal for Emerging Scholars of Japanese Studies in Australia Edited by Dr Christine de Matos

\section{ARTICLES}

1 The Impact of the Telegraph on Anglo-Japanese Diplomacy during the Nineteenth Century Jack Nicholls

23 Things That are Near Though Distant:

Extramarital Affairs in Heian-Period Japan Matthew Grubits

43 Learners' Participation in Informal Japanese-English Internet Chat Sarah Pasfield-Neofitou

64 Japanese wives in Japanese-Australian intermarriages Jared Denman

\section{ONLINE ARTICLES (ABSTRACTS)}

85 Thinking outside the Chinese Box: David Mitchell and Murakami Haruki's subversion of stereotypes about Japan

Chikako Nihei

86 Teaching culture in the Japanese language classroom:

A NSW case study

Caroline Mahoney 